\title{
Gold Placers of the Historical ForTyMiLe River Region,
}

Alaska

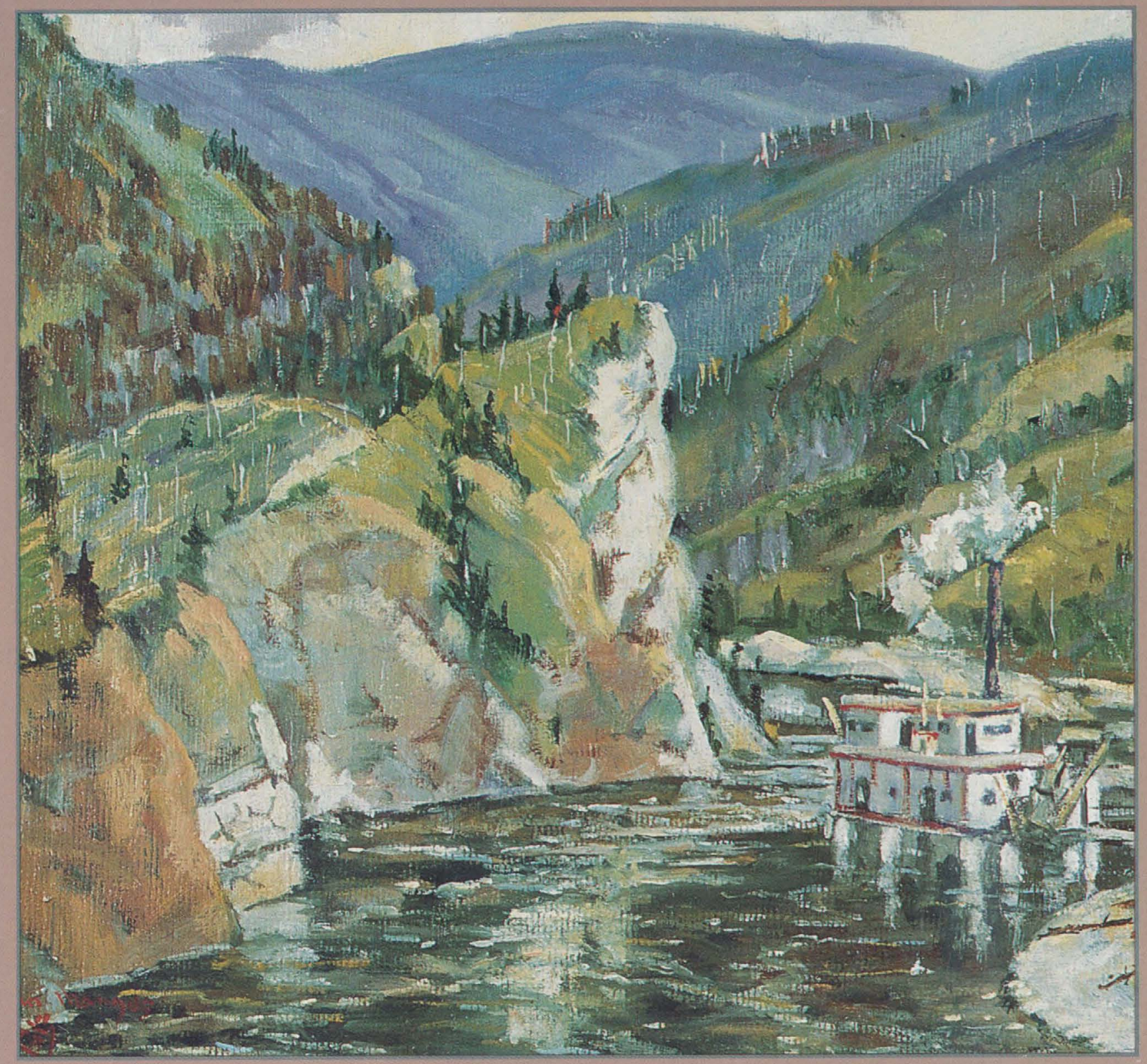




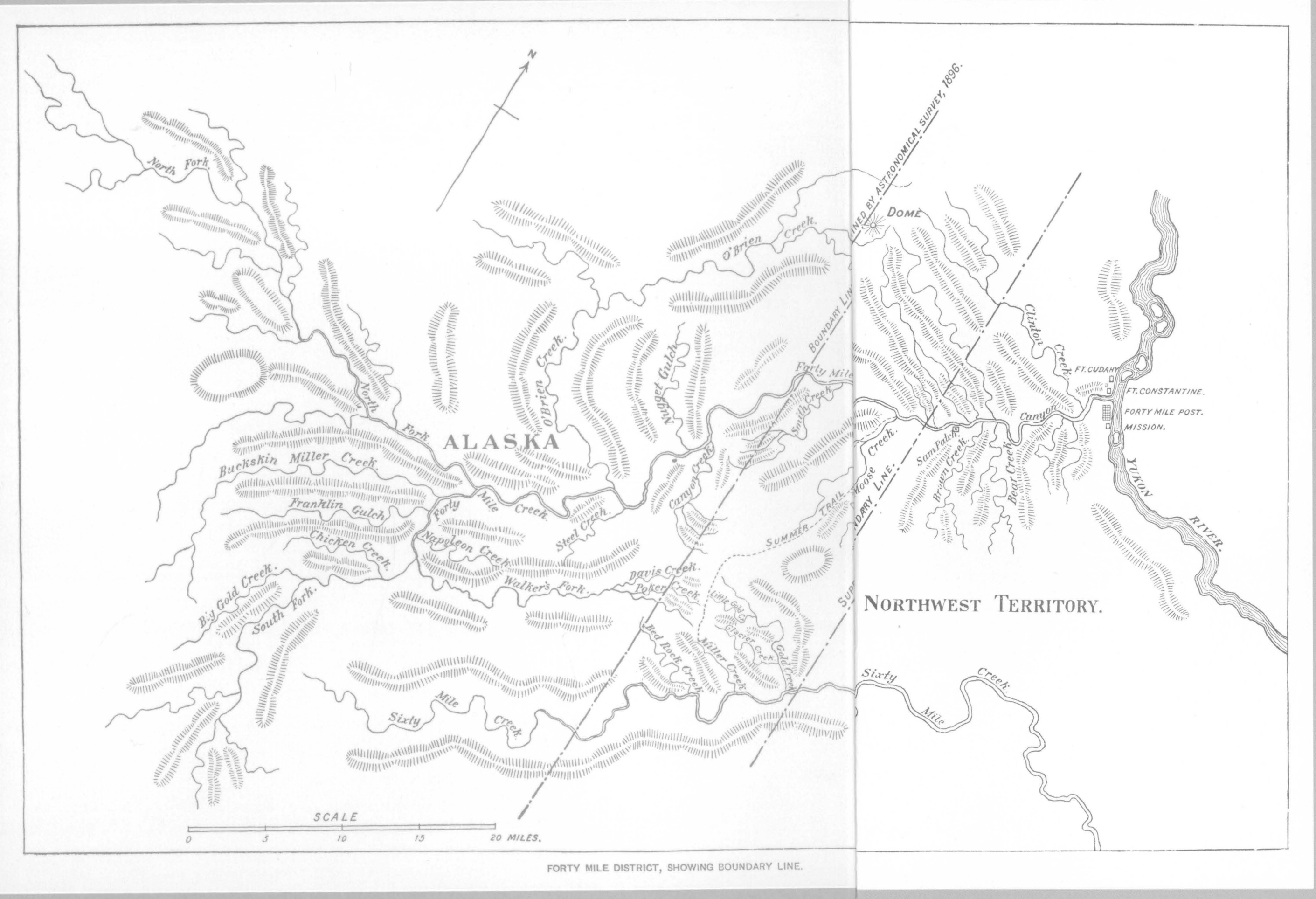

ORIGINAL MAP of Fortymile Mining 


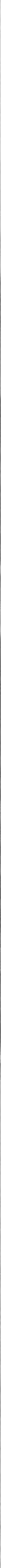


WARREN YEEND

\section{Gold Placers of the Historical ForTyMILE RivER REgION, AlaskA}

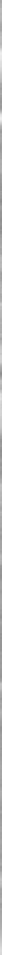

U.S. Geological Survey Bulletin 2125 


\section{U.S. DEPARTMENT OF THE INTERIOR BRUCE BABBITT, Secretary}

\section{U.S. GEOLOGICAL SURVEY \\ Gordon P. Eaton, Director}

Text and illustrations edited by Carolyn Donlin and Julia Thomas

Plate edited by Julia Thomas, designed and prepared by Stephen Scott Graphics prepared by Sara Boore, Susan Mayfield, and Warren Yeend Book designed by Sara Boore and Susan Mayfield

Any use of trade, product, or firm names in this publication is for descriptive purposes only and does not imply endorsement by the U.S. Government

UNITED STATES GOVERNMENT PRINTING OFFICE, WASHINGTON: 1996

For sale by

USGS Map Distribution

Box 25286, MS 306, Building 810

Denver Federal Center

Denver, CO 80225

\section{Library of Congress Cataloging-in-Publication Data}

Yeend, Warren E., 1936-

Gold placers of the Historical Fortymile River region, Alaska / by

Warren Yeend

p. cm. - (U.S. Geological Survey bulletin; 2125)

Includes bibliographical references.

Supt. of Docs. no. : I 19.3:2125

1. Geology-Alaska. 2. Gold ores-Alaska. 3. Placer deposits-

Alaska. I. Title. II. Series:

QE75.B9 no.2125

[QE83]

96-29154

553.4'1'097986-dc20 


\section{CONTENTS}

ABSTRACT

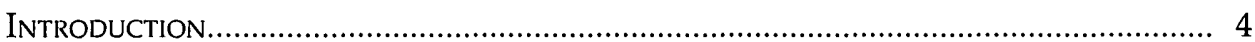

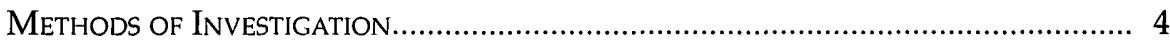

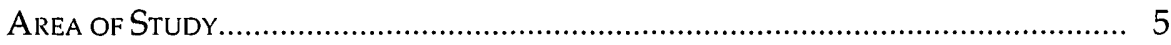

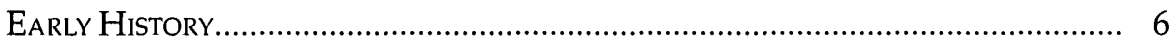

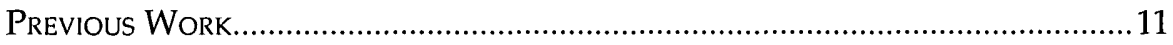

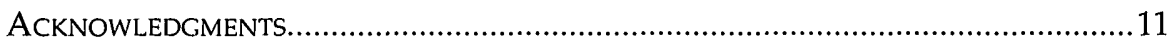

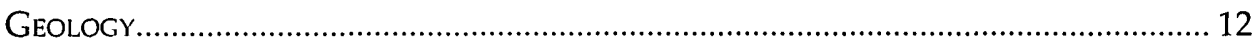

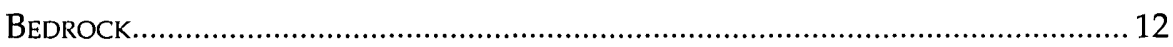

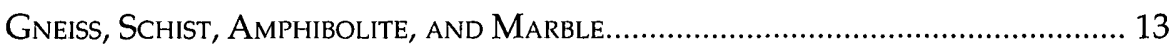

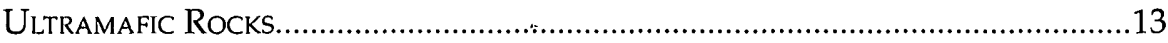

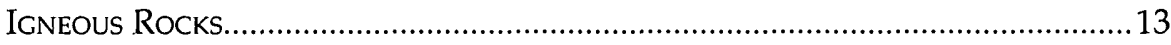

Sandstone, Conglomerate, Siltstone, Shale, and Coal.................................14

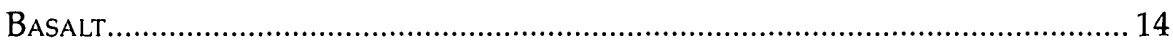

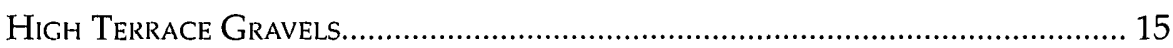

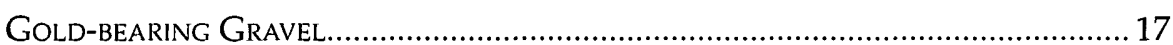

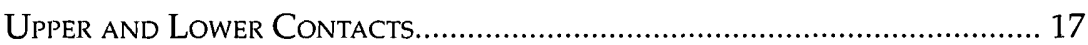

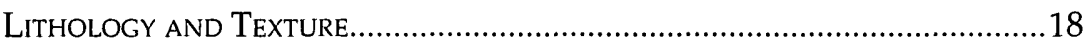

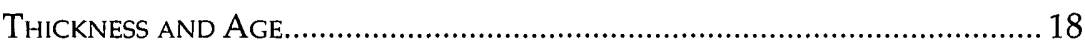

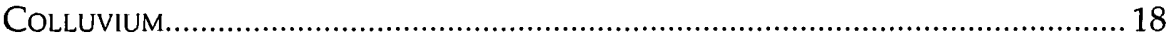

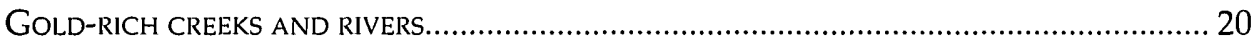

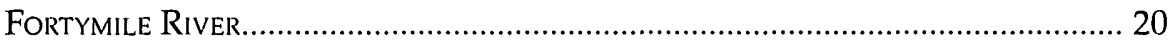

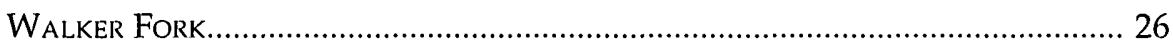

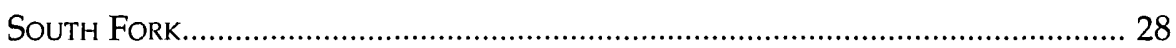

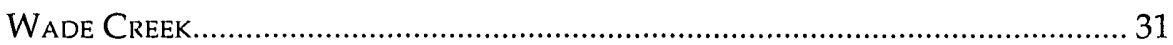

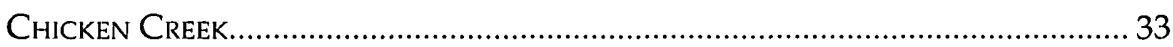

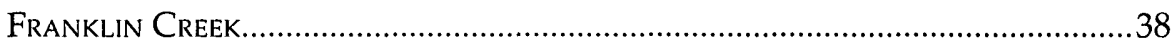

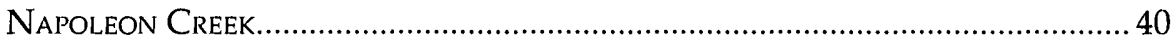

Lost Chicken Creek and Lost Chicken Hill....................................................4

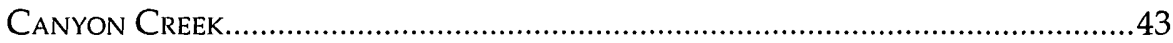

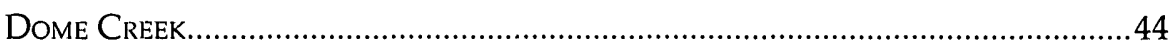

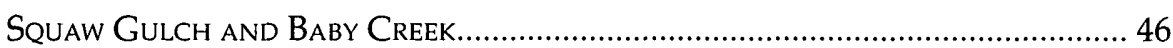

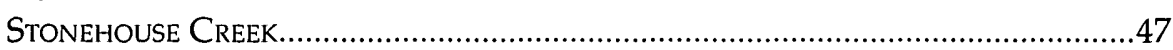

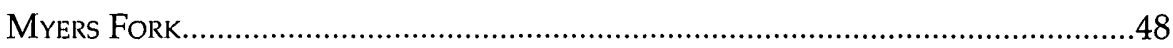

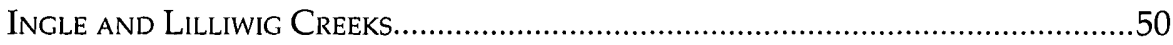

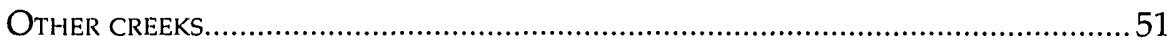

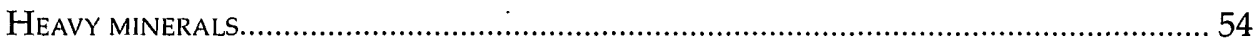

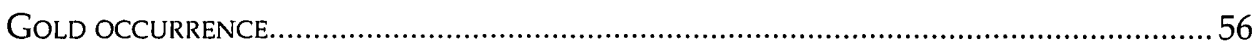

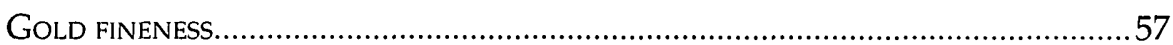

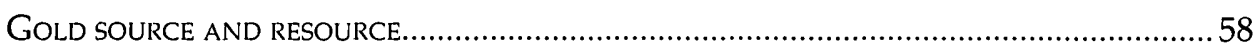

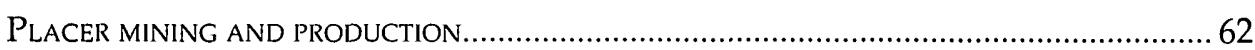

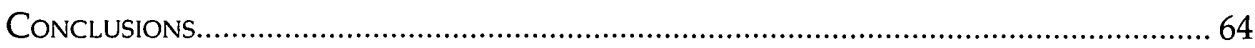

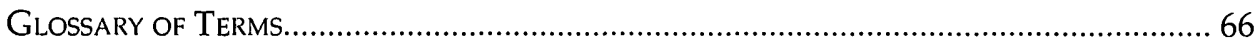

REFERENCES CITED 


\section{ILLUSTRATIONS}

Plate 1. Geologic map showing gold placers, Fortymile River area, east-central Alaska Figures

1. Index maps showing study area and detail of study area.................................................... 5

2. Photographs of L.S. (Jack) McQuesten and Arthur Harper..................................................... 6

3. Photograph of Fortymile City, Canada, in the 1890 's.................................................................. 8

4. Map of Fortymile Mining District showing misplaced boundary between Alaska and Canada.

Photographs 5-8 showinc:

5. Blocky outcrop of gneiss and schist exposed along South Fork of Fortymile River. 13

6. High terrace gravels exposed in Napoleon Creek valley......

7. High terrace gravels exposed in barrow pit along O'Brien Creek...

8. Frozen muck banks of mine pit on south side of Lost Chicken Creek valley.............................17

9. Diagrammatic cross section showing Lost Chicken tephra bed............................................... 17 PhOTOGRAPHS 10-13 showing:

10. Probable first gold discovery site in Fortymile River.. 20

11. Aerial view of abandoned meander of North Fork of Fortymile River.....................................2.

12. Steele Creek town site at mouth of Steele Creek............................................................................22

13. Winter mining in Fortymile River at "Swansons Diggings" in 1921....................................... 23

14. Diagram showing typical gold-diving operation using a suction dredge.................................23

15. Photograph of pothole developed in gneiss exposed in Fortymile River.................................. 24

16. Graph showing profiles of present and ancestral river gradients..............................................25 PHOTOGRAPHS 17-41 SHOWING:

17. Aerial view toward east of Fortymile River showing its narrow, V-shaped canyon.................25

18. Aerial view of Davis and Poker Creek valleys............................................................................26

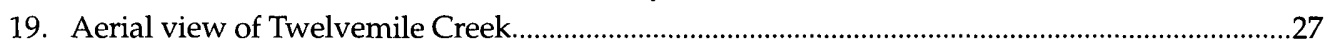

20. Atwater Dredge on South Fork of Fortymile River between Franklin and Buckskin Creeks...........29

21. Remains of Lost Chicken Dredge on Mosquito Fork ..............................................................30

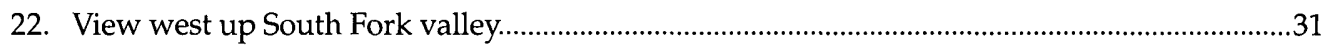

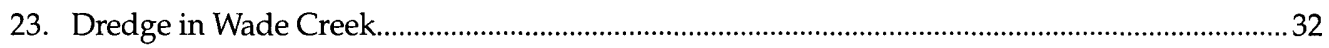

24. Large gold nugget recovered from Wade Creek ..........................................................................33

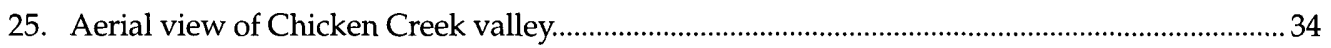

26. Oil painting by Marvin Mangus of town of Chicken as it looked in the $1920^{\prime} \mathrm{s}$ and 30 's...........35

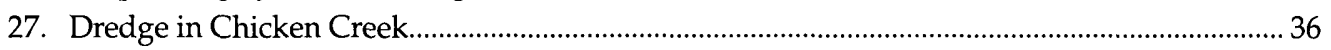

28. Placer mining in Chicken Creek using a dragline and elevated trommel............................... 36

29. Purdy Quartz Mine on ridge northeast of Myers Fork ............................................................ 37

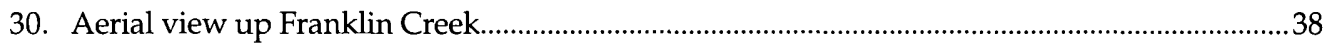

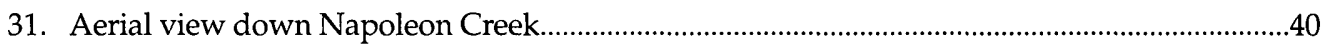

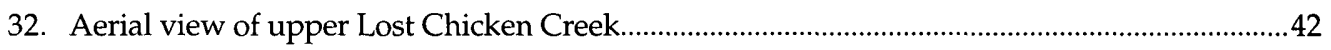

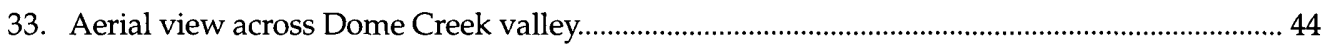

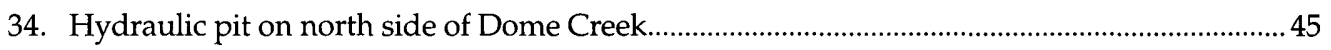

35. Coarse gold recovered from Baby Creek ........................................................................................47

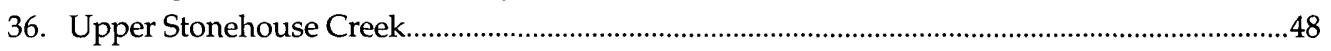

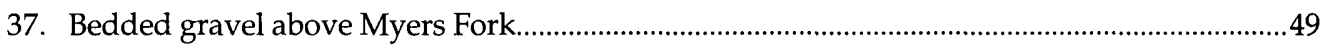

38. Aerial view of junction of Ingle Creek and Mosquito Fork of Fortymile River........................ 50

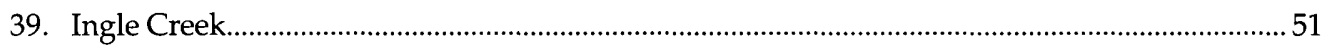

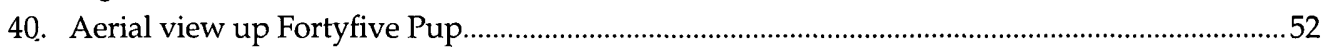

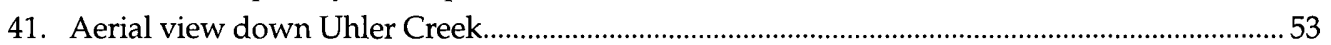




\section{TABLES}

Table1. Pebble counts expressed in percentages for selected localities from high terrace gravels, Fortymile Mining District, Alaska.

Table 2. Pebble counts expressed in percentages for selected localities in Walker Fork drainage, east-central Alaska.

Table 3. Pebble counts expressed in percentages for selected localities in South Fork of Fortymile River, east-central Alaska.

Several illustrative photographs are included that are not numbered in the text. All recent photographs taken by author, unless otherwise noted.

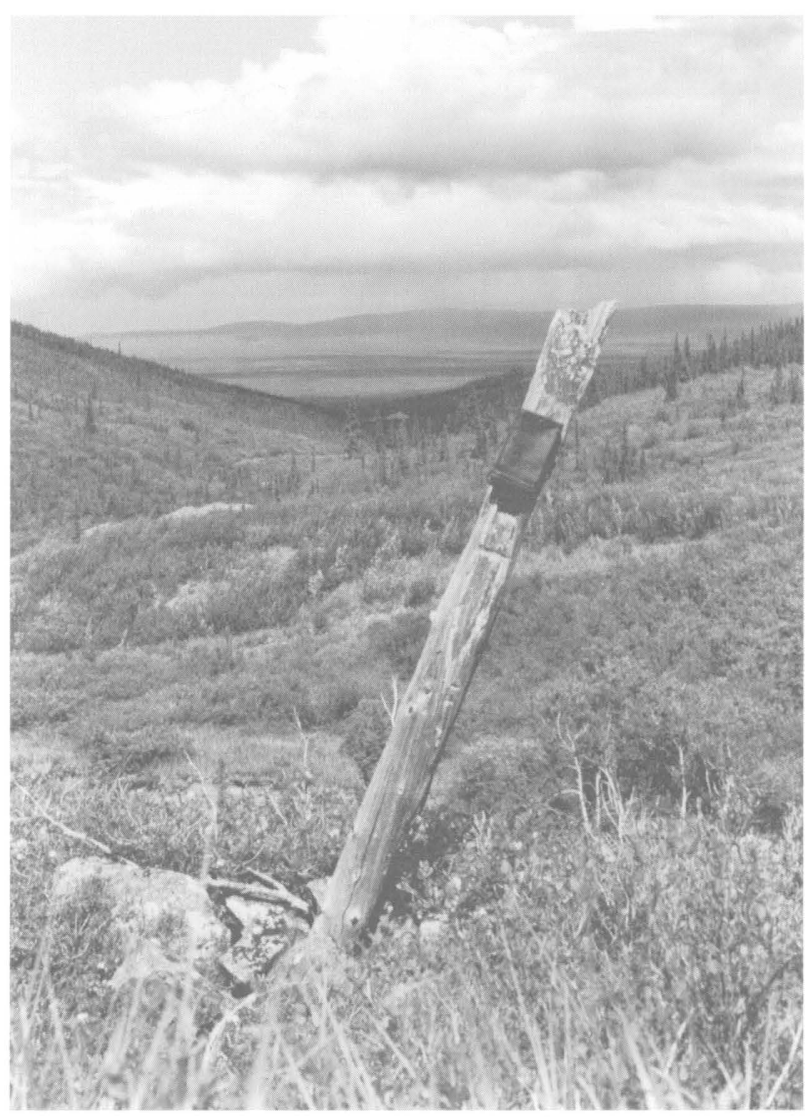

CLAIM MARKER in Circle Quadrangle. Cigar can holds the claim notice. Photograph taken in summer of 1980 . 


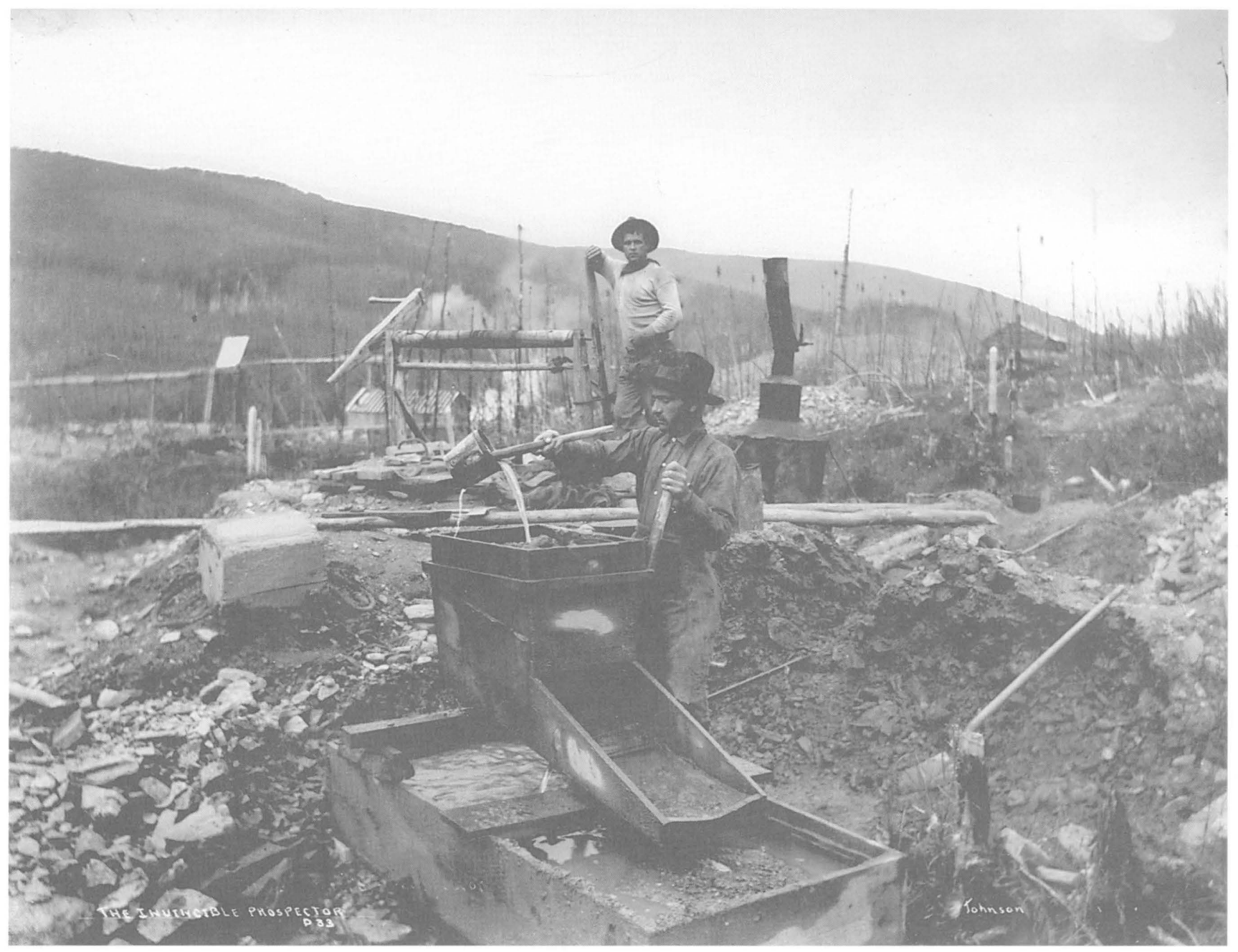

Frontispiece HAND MINING IN INTERIOR ALASKA. The miner in foreground operates rocker and man behind operates windlass used for hoisting thawed gold-rich gravel to the surface from underground. This method of mining was common in the late 19th century in the Fortymile River area. Photograph by Albert Johnson. Photograph courtesy of University of Alaska, Fairbanks (From the Albert Johnson Collection, accession number 89-166-635N in the Archives, Alaska and Polar Region Department). 
Gold Placers of the Historical Fortymile River Region, Alaska 


\section{AbStRact}

The Fortymile River region in east-central Alaska has a long and colorful history as the site of the first major gold discovery in interior Alaska. Placer gold has been mined in the region nearly every year since its original discovery in 1886 . Total gold production is approximately 500,000 troy ounces. Although many of the rich deposits have been mined, there still exist areas that contain gold. Areas of mined and unmined gold-bearing creek and terrace gravels are outlined on the accompanying geologic map.

The early history of the Fortymile area centered on the small frontier settlement of Fortymile City located at the junction of the Fortymile and Yukon Rivers in Canadian territory. This was the supply and jumping-off point for prospectors who worked their way into Alaska up the Fortymile River and found gold on many of its tributaries. Hand mining, both underground and surface, using sluice boxes and (or) rockers were the earliest methods; later, hydraulicking, dredging, and draglining methods were used. More recently, bulldozers and elevated trommels have been used, as well as very portable floating suction dredges. The rich mining lore of the area is closely associated with events of the nearby world-famous Klondike District. Bedrock and placer geology and mining history of individual gold-rich creeks are herein updated.

The Fortymile area, which is part of the Yukon-Tanana Upland, contains quartzite, schist, gneiss, amphibolite, marble, serpentinite, and granite overlain by basalt, sandstone, conglomerate, shale, tuff, and coal; overlying these rocks are several deposits of varying ages consisting of gold-bearing gravel and colluvium. The close spatial association of creeks containing placer gold and the gneiss, schist, amphibolite, and marble unit strongly suggests this metamorphic unit is the gold source.

High terrace gravels record a time from the late Tertiary to early Pleistocene when the ancestral Fortymile River and its major tributaries, the North and South Forks, had floodplains roughly 1 to 2 miles (2-3 kilometers) wide and gradients of about 4 feet per mile ( 0.75 meters per kilometer). Base-level lowering during the post-early Pleistocene caused the rivers to cut into their floodplains and to develop the youthful characteristics they have today such as V-shaped canyons, narrow floodplains, and gradients of at least twice those of the old river.

Colluvium marginal to creek deposits in steep-sided valleys is often gold bearing. Much of the unconsolidated gravel within the major drainages of the Fortymile River, South Fork, North Fork, and Mosquito Fork is colluvium.

Heavy-mineral-concentrate samples from the gold-producing creeks and high terrace gravels contain varying amounts of magnetite ( 20 to 80 percent) and ilmenite (10 to 30 percent), and samples from creeks draining areas principally composed of metamorphic rocks contain abundant garnet (10 to 30 percent). Gold fineness ranges from 620 to 927 , but it is difficult to attach any geologic significance to the fineness data. 
Most placer gold in the Fortymile River area has been recovered at, or near, the gravelbedrock contact. The lowermost 3.3 feet ( 1 meter) of gravel and the uppermost 1.6 feet $(0.5$ meter) of bedrock may contain as much as 80 to 90 percent of the gold that is ultimately recovered. Gold nuggets are rare and most of the gold recovered is in the form of flattened fragments less than .2 inches ( 5 millimeters) in greatest dimension. However, large gold nuggets have been found on Wade Creek; examples are ones of 25, 33, 56, and 70 ounces. Occasionally, large nuggets may still be found in the tailing piles along the creek.

The Fortymile River and its tributaries the South Fork, Walker Fork, and Mosquito Fork, all of which at one time were the sites of bucket-line dredge operations, now are almost exclusively mined using floating suction dredges. Unmined gold-bearing gravel is present in the floodplain of the Walker Fork valley below Cherry Creek and in low (about 100 to 130 feet or 30 to 40 meters) terraces along the north side of Walker Fork and east side of Cherry Creek. Considering the locations of where most gold has been found in the South Fork valley both by the older bucket dredges and the modern suction dredges, it seems likely that the tributary drainages of Lost Chicken, Napoleon, Franklin, and Buckskin Creeks have supplied the bulk of the gold to the South Fork valley. A quarter acre ( 0.10 hectare), 130 -foot-thick ( 40 meters) section of the high terrace gravels on the north side of Napoleon Creek was mined for placer gold and yielded values estimated to be $\$ 8.50$ per cubic yard (or $\$ 6.50$ per cubic meter) at $\$ 350$ per troy ounce. The unmined high terrace gravels on the south side of Buckskin Creek contain gold; however, this gravel is only 3 to 6.5 feet ( 1 to 2 meters) thick.

The search for a lode gold source in the Fortymile River region may be in vain, because substantially more gold than has been recovered from the placers can be derived by the gradual erosion of large volumes of source rocks that contain background mean gold amounts. Using Leon's mass balance equation, 5,167 metric tons of gold may exist in the placers of the Fortymile River region, less than 1 percent of the recovered amount of 15.6 tons.

The largest gold resource remaining in the Fortymile River region is probably in the high terrace gravels exposed along many of the creeks and rivers. Until there is exploratory drilling or a comprehensive sampling program, the amount of gold in these gravels will remain unknown. Environmental constraints imposed by Federal and State agencies have slowed, but not stopped, placer mining in the Fortymile River area, and a significant gold price rise would result in more mining.

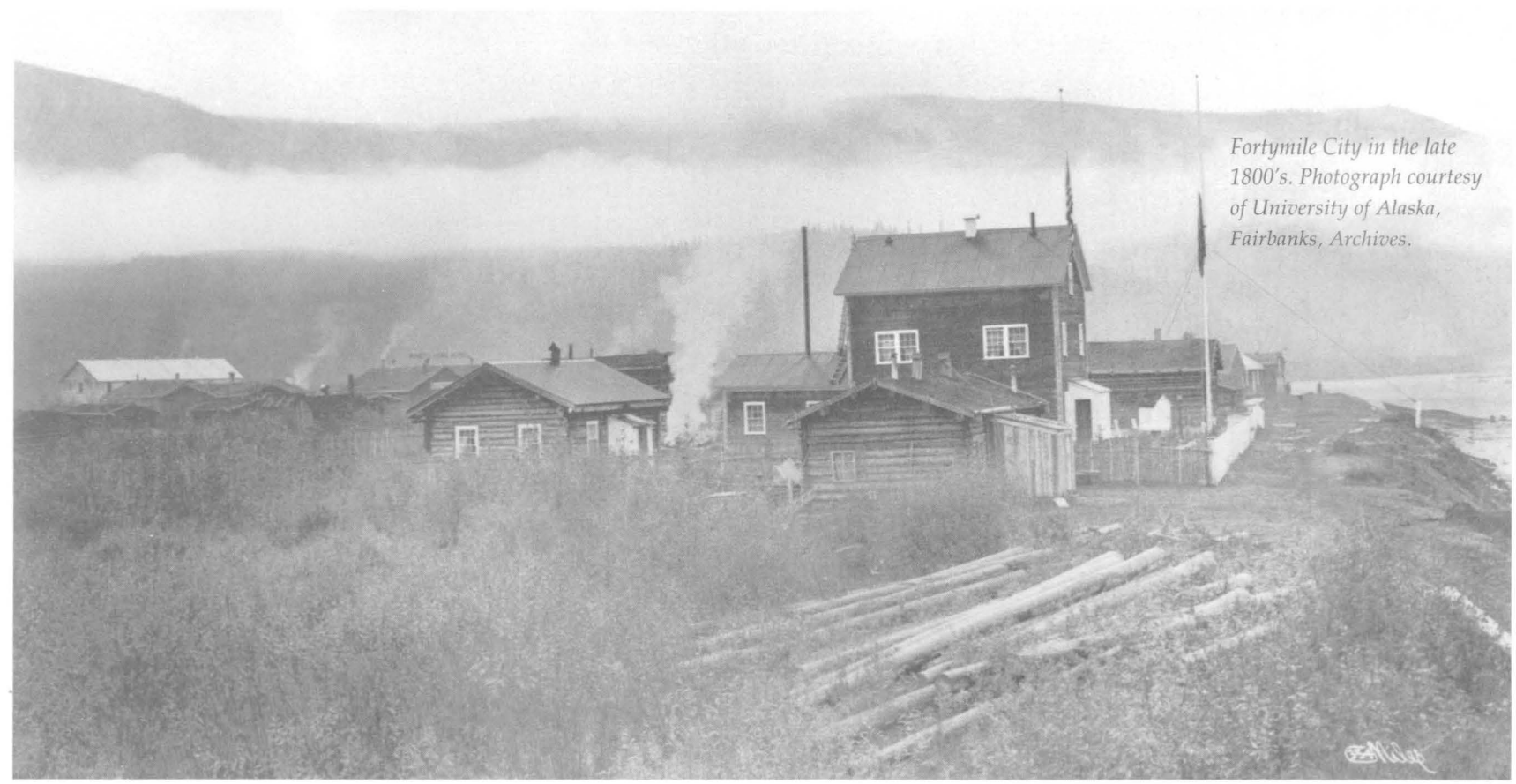




\section{INTRODUCTION}

The Fortymile River area was the site of the first major gold discovery in interior Alaska. Placer gold has been mined in the region nearly every year since its original discovery in 1886 . Total production is about 500,000 troy ounces. Although the creeks have been repeatedly mined, placer gold can be found in alluvial and colluvial deposits marginal and upvalley from mined creek deposits, in some tailings, and in the extensive high terrace gravels marginal to many of the larger creeks and rivers. This report focuses on the placer geology of individual creeks; mining, history of the area, which has not received attention since Mertie (1938); the high terrace gravels; and the gold source. The first detailed map showing the occurrence of mined and unmined gold-bearing gravels (pl. 1) is included herein.

Recognized conventions used in the mining of and description of placers are as follows: Gravel is usually measured in cubic yards and gold in troy ounces. A cubic yard of gravel in place usually weighs approximately 3,000 pounds $(1,360$ kilograms); one ounce troy equals 1.097 ounces avoirdupois (the commonly used system of weight). One troy ounce equals 20 pennyweights, which equals 480 grains.

I wanted the gold, and I sought it; I scrabbled and mucked like a slave. Was it famine or scurvy-I fought it; I hurled my youth into a grave. I wanted the gold, and I got itCame out with a fortune last fall, Yet somehow life's not what I thought it, And somehow the gold isn't all.

The Spell of the Yukon-Robert Servuce
All references to ounces in this report are to ounces troy, all those to pounds are to pounds avoirdupois. The price of gold until 1934 was $\$ 20.67$ an ounce, and from 1934 until 1968 it was $\$ 35$ per ounce. Since then it has ranged up to $\$ 850.00$ per ounce in 1980 and then down to $\$ 284.25$ in 1985 (Parker, 1992). Values computed for this report are for a gold price of $\$ 350$ per ounce, a long-term predicted average gold price (Mackenzie, 1991).

\section{Methods of Investigation}

Fieldwork in the Fortymile River region was conducted during parts of June and July 1990, 1991, and 1992, for a total of about 9 weeks. Black and white 1954, 1955, and 1957 aerial photographs, scale 1:50,000, were used to plot sample locations and geologic contacts, which were subsequently transferred to topographic quadrangle maps (1:63,360 scale). The creek gravels were described and lithologies were based on pebble counts of 100 cobbles and pebbles. Stream-sediment samples collected at 56 sites were screened (with a minus-10-mesh screen) and panned in the field. Panned concentrates were dried for mineral identification and detailed laboratory study. Mining operations were observed and discussions with placer miners were helpful in determining gold values and mining characteristics of the different gravels. Stratigraphy was described at mining and natural cuts and unit thickness noted in detailed field sketches. A helicopter was used for 4 days during July of 1992 to obtain access to placer-rich areas remote from roads, take aerial photographs for illustrations, and to map areas of mined and unmined gravels. 


\section{Area of Study}

The Fortymile River region (fig. 1) includes most of the southeast quarter of the Eagle Quadrangle (1:250,000 scale). The mapped area includes all of Eagle A-1 and A-2; and parts of the Eagle A-3, B-1, B-2, and B-3 topographic quadrangles (pl. 1). The area consists of most, but not all, of the Fortymile Mining District (fig. 1), as defined by Cobb (1973). This area was studied because it includes the creeks from which most of the placer gold in the Fortymile District was mined and because it probably contains the bulk of the unmined placer gold deposits in the district.
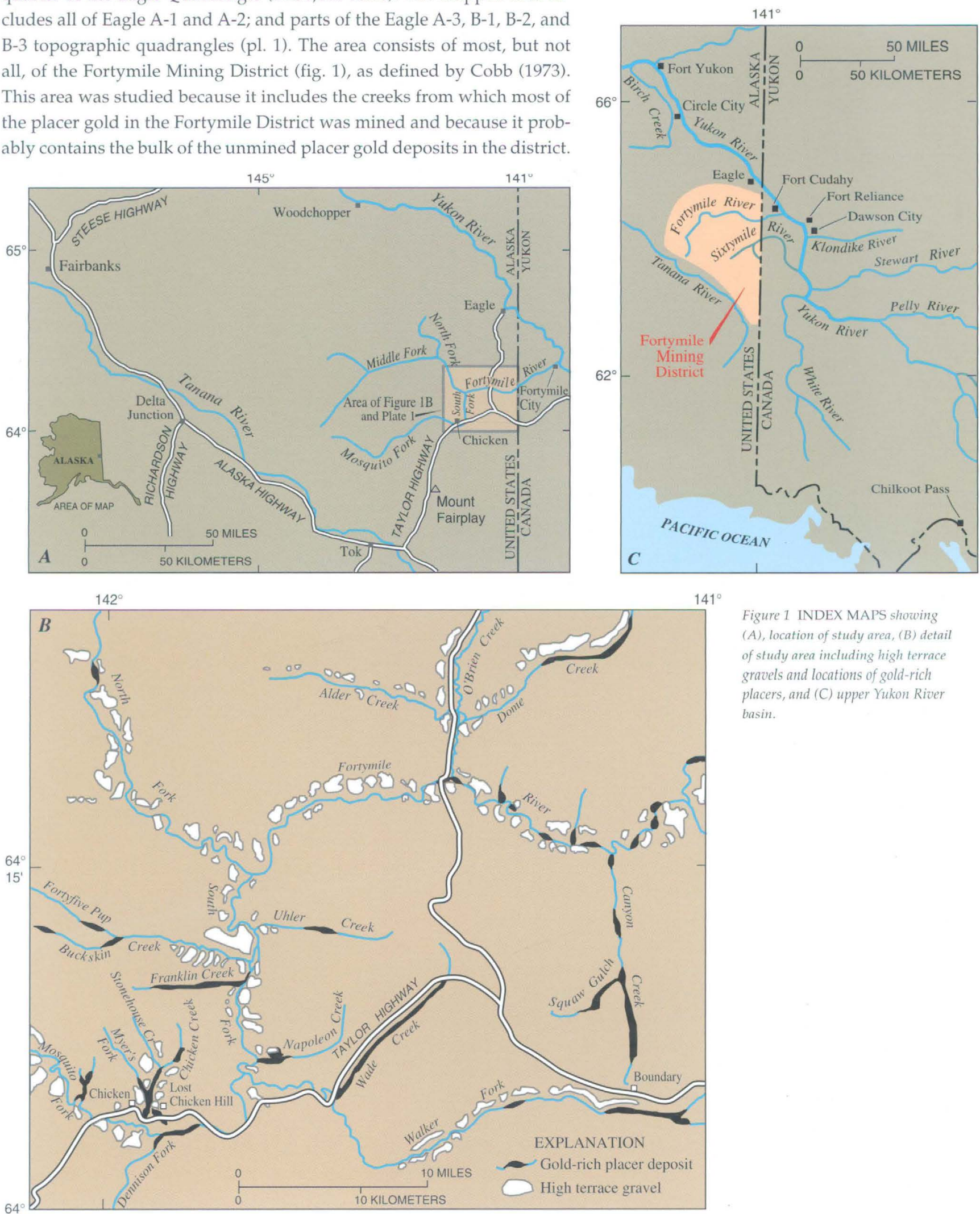

Figure 1 INDEX MAPS showing (A), location of study area, (B) detail of study area including high terrace gravels and locations of gold-rich placers, and (C) upper Yukon River basin. 


\section{EARLY History}

Three hardened and seasoned prospectors were to play a pivotal role in the early gold discoveries of the upper Yukon basin. They were L.S. (Jack) McQuesten, Arthur Harper, and Alfred Mayo. McQuesten and Harper (fig. 2) are legendary for their devotion to the development of the region and will be long remembered for the important role they played in opening up of the area to prospectors and miners. Their knowledge of the country in the $1870^{\prime}$ s and 1880 's was relied on by the many prospectors and fur hunters because neither

Figure 2 L.S. (JACK) MCQUESTEN (shown left) AND ARTHUR HARPER (shown right) are legendary figures in the early history of the upper Yukon Basin. Although they were primarily fur traders, they occasionally worked as prospectors and explorers. They were responsible for opening up the Fortymile River area for prospectors and miners. Photographer unknown.
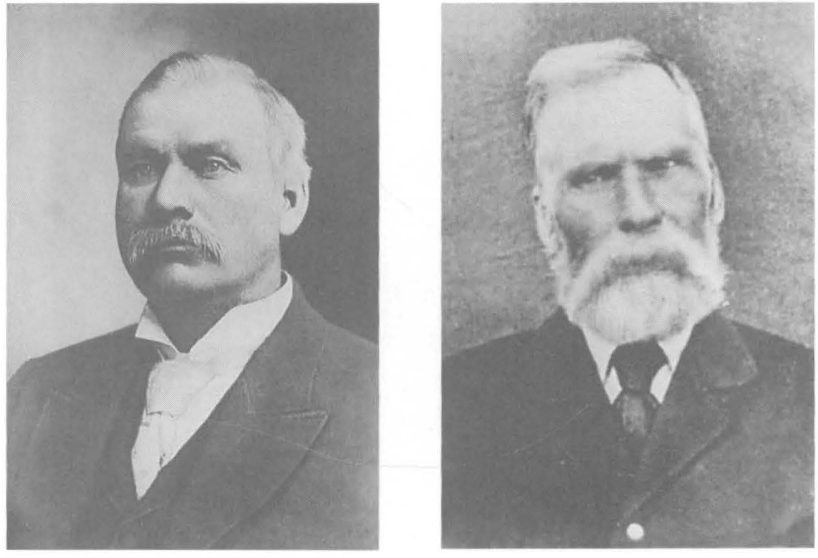

the Canadian or American Governments had made any surveys or investigations of the country. The writer Jack London, who met McQuesten along the Yukon River in 1898, extolled the virtues of these three men, and their important contribution to the early history of the region (London, 1903). Harper, the inveterate prospector, roamed the upper Yukon

River and its tributaries for 25 years exploring among many others four rivers that would ultimately yield fortunes in gold - the Stewart, Fortymile, Tanana, and the Klondike-yet he missed the big discovery (Berton 1958). We pick up the story when Francois Mercier, a French Canadian who was destined to dominate the Yukon trading frontier in the 1870's and 1880's decided to establish a trading post in the upper Yukon River basin to tap into the trading potential of the Han Indian country. He picked McQuesten, who had come north from the United States looking for gold, to head the post. Traveling up the Yukon River on the first steamboat on the river, and appropriately named the Yukon, Mercier picked a spot in Canadian territory 6 miles (a little over 9.5 kilometers) below the mouth of the Klondike River and named the post Fort Reliance (Clark, 1995). This post subsequently became the benchmark from which several important tributaries to the Yukon River were named, such as the Fortymile River, which is 40 miles (a little over 64 kilometers) down the Yukon from Fort Reliance; and Sixtymile River, which is 60 miles (96.5 kilometers) upriver from Fort Reliance. In 1874 Harper and two members of his party, George Finch and Frederick Hart, found "good prospects" at the mouth of the river they afterwards named "Fortymile." They were about to ascend the river and continue prospecting, but Indians camped nearby indicated that a dangerous canyon was present through which they would have to traverse and this information so discouraged the prospectors that they decided against the upriver trip (Ogilvie, 1913). Had they made the upriver trip, history for this part of the Yukon basin would undoubtedly have been different than it subsequently played out. Thirteen more years went by before the significant gold deposit would be discovered on the Fortymile River. In 1875 Harper and Mayo, not having much success finding gold, joined forces and operated the Fort Reliance post while McQuesten moved to Fort Yukon to trade. In 1879 McQuesten returned to Fort Reliance. In addition to their trading duties McQuesten, Harper, and Mayo spent some time each summer and fall prospecting for gold by exploring tributaries of the Yukon including the Tanana, Fortymile, Sixtymile, White, and Stewart Rivers. Although they found some gold, they did not find enough to stake a claim.

In 1882 another group of prospectors traveling via Chilkoot Pass arrived on the upper Yukon. Among these men were three who would play a major role in the mining 
development of the area-Joseph Ladue, Howard Franklin, and Harry Madison. The men wintered near McQuesten at Fort Reliance and, anticipating that gold would be found, they drew up laws governing the size of placer claims, water rights, and recording methods (McQuesten, 1952).

In the $1870^{\prime}$ s and early $1880^{\prime}$ s, trading was the primary activity in the upper Yukon basin, but after 1885 mining became dominant. McQuesten along with his partners, Harper and Mayo, and financed by the Alaska Commercial Company, were eager to capitalize on their situation. A small gold strike was made in the spring of 1885 on the Stewart River in Canada, which prompted McQuesten and his partners to abandon Fort Reliance and move to accommodate the miners on the Stewart River. The gold found here was fine gold that required the use of mercury to effect its recovery, and, although it was found in paying quantities-as high as $\$ 100$ per day in some instances-fine gold never satisfied the early miners and prospectors (Ogilvie, 1898). Stewart River was not large enough to provide employment to all the miners and prospectors moving into the area, and they fanned out to search other streams and rivers.

In 1881 Arthur Harper and a Mr. Bates collected some gold-rich gravel from the North Fork of the Fortymile that, when later assayed, proved very rich $-\$ 20,000$ to the ton. Harper was unable to relocate the site the following year (Wharton, 1972).

In September of 1886, Howard Franklin and five other prospectors began to work up the Fortymile River panning every sandbar that they encountered. Although gold was obtained at each bar, values were low, 15 cents to the pan.

\footnotetext{
"It was on the evening of the 7th (of September)," he recounted, "that I left the camp and walked upstream about two miles. I found a place where the bedrock was exposed, and in a crevice succeeded in getting out a shovelful of dirt. When I panned this I was surprised to find that it had much coarse gold in it. I hastened back to camp and showed the boys what I had got. We weighed the prospect and if I am not mistaken it weighed a half an ounce, or about $\$ 8.50$ as gold went in those days. This place was about 500 feet ( 150 meters) inside the American boundary line" (Paterson, 1977).
}

Franklin proceeded upriver and about 25 miles ( 40 kilometers) from the mouth of the Fortymile staked a claim on what eventually would be known as Franklin Bar (Brooks, 1973). Harry Madison, Red O'Brien, Phil Brown, Jim McAdams, and Henry "Tuck" Lambert may have accompanied Franklin in this first discovery (Webb 1985; Davis, 1967; Paterson, 1977). Frank Buteau (1967) claimed that the gold discovery party included four men, Franklin, Lambert, Micky O'Brien, and Madden. The Franklin Bar claim was 1,500 feet (457 meters) in length along the river, which was the amount allowed for one claim according to the mining laws of the Alaskan territory (Heller, 1967). Prospectors Lambert and Madden located another claim (Madden Bar) about 10 miles (16 kilometers) above Franklin Bar. This strike on the Fortymile River was recognized as a rich one, more so than that at Stewart River; it was the first coarse gold discovery on the Yukon River or any of its tributaries (Ogilvie, 1890) and easily obtained from a shallow depth in the gravel of the bars. The firm of McQuesten, Harper, and Mayo once again moved to where the "action" was and established a trading post/store at the mouth of the Fortymile River in 1887 (Ogilvie, 1913), a location that would become the first town (called Fortymile City, Fortymile, or Fortymile Post) in the upper Yukon basin (fig. 3). 
Sixteen prospectors, known as the Sixteen Liars because of their tall tales, were in the area by the spring of 1887 , and they agreed to locate claims of only 300 feet (91 meters) each in light of what initially seemed to be a very gold-rich region. Frank Buteau staked a claim at Bonanza Bar about midway between Franklin Bar and Madden Bar, and he was to become known as "King of the Fortymile" as he took out more gold (150 ounces) than any other miner during that first mining season of 1887 (Heller, 1967). Bonanza Bar is the only name that is still used from these first locations (pl. 1). The tales of Frank Buteau (1967) and Henry Davis (1967) are an excellent source of information on details of first discoveries,

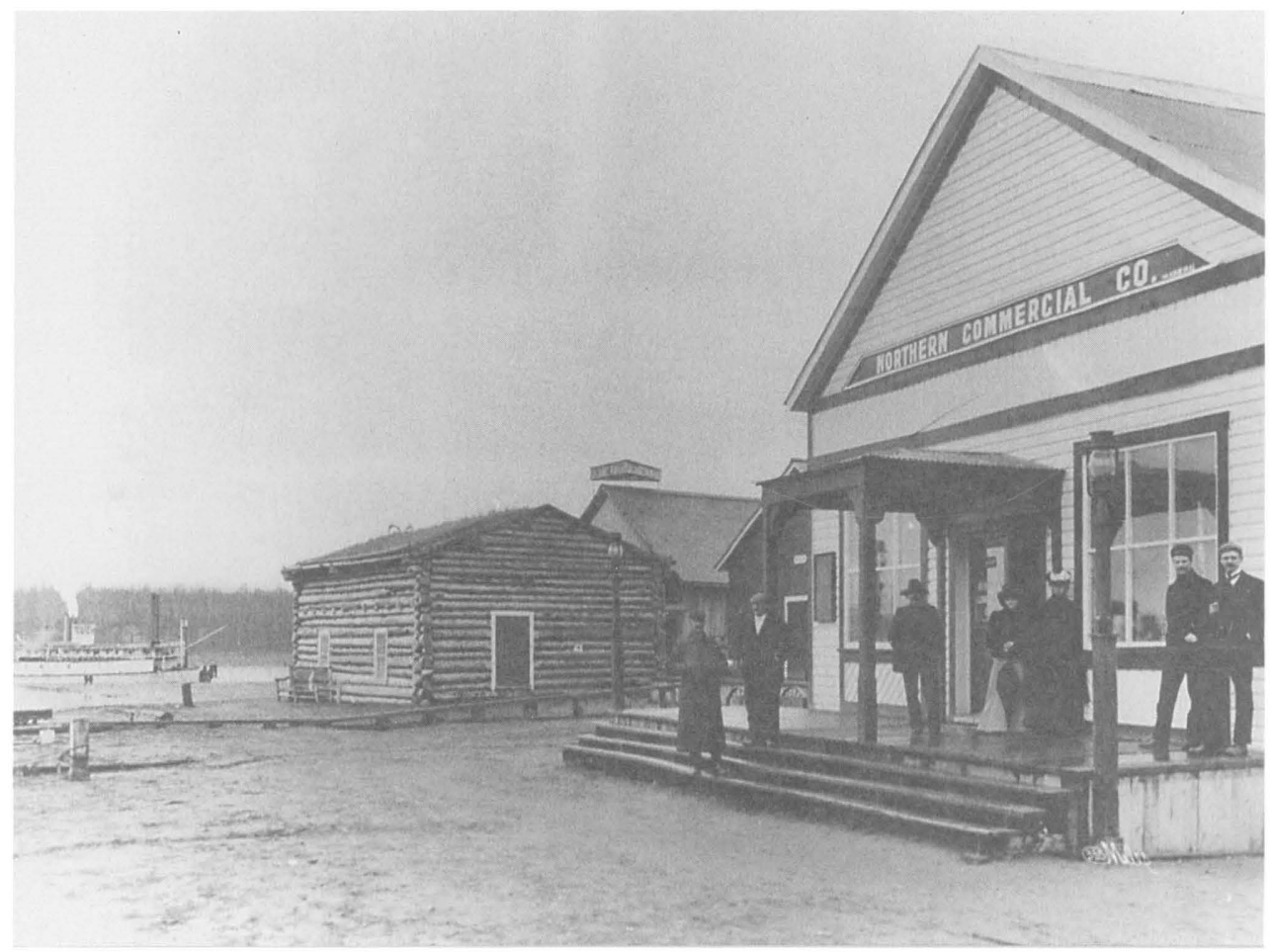
early mining methods, gold values, living conditions, and the earliest history of the district, and they make fascinating reading.

Until the discovery of gold in the Fortymile region, most placer mining in the upper Yukon River country had consisted of shallow workings called "skim diggings." They were often bars in midstream with fine gold. Franklin's find was the first continuous paystreak found on any creek along the Yukon (Wickersham, 1938). The discovery of coarse gold at a depth of several meters, near or at the base of the alluvial gravel made the perma-

Figure 3 FORTYMILE CITY, CANADA, IN THE 1890 'S. View toward the east. Yukon River with riverboat shown in background. Located at the junction of the Fortymile and Yukon Rivers, this town supplied the mines in the Fortymile Mining District. It was the place where the discoverers of the Klondike came to tell the world and record their claims. The townsite is overgrown with trees and shrubs today, although remnants of a few original buildings can be found. Photograph courtesy of University of Alaska, Fairbanks, Alaska. (From the Erskine Collection, accession number 70-28-1116 in the Archives, Alaska and Polar Regions Department). frost, or as the early miners termed it "frost," an obstacle to mining. Many of the miners considered the "frost" an insuperable barrier and concluded that bedrock could not be reached by any practicable method. It is to William Ogilvie, Canadian Government surveyor and explorer of the upper Yukon River valley, that credit should be given for helping to solve this problem. He remembered seeing holes burned through the frozen crusts of streets in Ottawa, Canada during the winter, to reach defective gas and water pipes. He suggested this method as he had seen it applied, using the local wood resources instead of coal and coke used in the city. The method was tried and proved to be an instant success. The method used by the early miners consisted of building a fire over the ground that was to be thawed, about 3 by 6.5 feet ( 1 by 2 meters). The fire was allowed to burn 8 to 10 hours, and the thawed ground was then removed. Another fire was started in the excavated hole and the process repeated until bedrock was reached. Generally 1.5 to 3 feet ( 0.5 to 1 meter) of dirt and gravel would be removed with each fire-building cycle. The miner could then use the same method to drift along the paystreak at the gravel-bedrock contact. It was usually not necessary to timber the drift because the frozen ground would hold up. This method allowed for winter and (or) summer mining, but the excavated material would have to be washed for gold in the summer after it was thawed (Ogilvie, 1913).

In July of 1887, the first steamboat stopped at the Fortymile Post. Prior to the arrival of supplies from the outside, the men here, 85 strong, subsisted, mostly on fish. The town of Fortymile, "the loneliest mining camp on the face of the Earth" (Funston, 1896), grew to 1,000 
inhabitants by the early $1890^{\prime}$ s. Located on a flat piece of land 700 to 800 acres (280-323 hectares) in extent (Constantine, 1895), it included two blacksmith shops, a sawmill, two general stores, two doctors, a theater, a brewery, an unspecified number of restaurants and hotels, a library and reading room, a debating society, an opera house, a dressmaker, a watchmaker, a billiards hall, a cigar factory, and at least 10 saloons (Berton, 1958; Paterson, 1977). The town contained about 200 cabins and 20 to 30 large buildings (Dunham, 1898). Lots, 100 by 150 feet (30 by 45 meters), were selling for $\$ 8,000$ (Spurr, 1900; Wharton, 1972). Nearby was an Anglican mission and school as well as an Indian settlement. A number of the residents kept small gardens and were fairly successful at growing vegetables. Several had plans for large market gardens (Ogilvie, 1897). Despite the fact that the townsite was in Canadian territory, it was really an American town obtaining supplies from the United States without customs payments, sending mail with U.S. stamps, and servicing mining claims that were almost all in Alaska. Fortymile was a cohesive community that espoused the Christian ethic; no man went hungry, and each man's cabin was open to any passer-by. Even if a man had no money, he could get an outfit without payment from the Harper and McQuesten store. Men shared their good fortune and, as part of the high ethics code, each who found gold on a new creek spread the news to one and all (Berton, 1958). During the 1887 season, 115 miners produced 10,000 to 15,000 ounces of gold from the Fortymile District (Dunham, 1898). The California technique of hydraulic mining was adopted in the Fortymile area in 1890 when Frank Buteau, George Matlock, and their partners flumed water from Franklin Gulch (now Franklin Creek) to their claims on the South Fork (Webb, 1985). Many miners remained year-round on the creeks adopting the underground mining technique of "burning and drifting."

Law and order administered by government came late to the Fortymile area. Neither the Canadian Government in Ottawa nor the U.S. Government in Washington was much interested in this remote wilderness, and most of the early prospectors preferred this lack of government-imposed law. The prospectors brought with them the beliefs and traditions of the California mining camps. One of these beliefs was that law was a personal affair predicated on the immediate needs of the time and the place. It was not until 1895 that the Canadian North-West Mounted Police established a post at Fort Cudahy, (fig. 4) which was just across the Fortymile River from Fortymile City (Hayne, and Taylor, 1897; Wharton, 1972). The law that the Canadian officials brought to Fortymile was immediately criticized by both American and Canadian citizens. In addition to requiring a $\$ 15$ recording fee, the claim size in Canada was limited to 500 feet $(152 \mathrm{~m})$ in length and the width of the valley bottom. A few miles to the west in Alaska, the recording fee was $\$ 2$ to $\$ 3$ and a claim could be 1,320 feet (402 meters) square (Wright, 1976). The Alaska-Canada boundary line was accurately surveyed by William Ogilvie and brushed out in those places where it crossed gold-rich rivers and creeks such as the Fortymile River, Poker and Davis Creeks, (fig. 4, pl. 1) and the headwater regions of Canyon and Smith Creeks (Ogilvie, 1913). Some of the richest ground the miners had assumed to be in Alaska, such as areas on Miller and Glacier Creeks (Sixtymile area), was actually in Canada. The Canadians understandably resented the local miners' laws that prevented any non-U.S. citizen from holding a claim on the Alaskan side of the border, yet allowed a U.S. citizen to hold a claim in Canada (Hayne and Taylor, 1897).

From 1886 to 1893 , Fortymile was the only producing gold camp in the Yukon basin. In 1893 gold was discovered on Birch Creek by two Indians educated in prospecting at Fortymile. Jack McQuesten established a store at Circle City to supply the new mining region, which drew many of the Fortymile miners (Yeend, 1991).

It was to Bill McPhee's Saloon in the town of Fortymile that George Washington Carmack came in August, 1896, to tell the world of his gold strike on Rabbit Creek, a tributary of the Klondike River, and record his claims (Dial, 1975). "Lying George," as he was 
Figure 4 MAP OF FORTYMILE MINING DISTRICT showing original misplaced Alaska-Canada boundary and names of the early mined creeks. Modified from Dunham (1898). nicknamed, was laughed off at first and many of the Fortymilers were reluctant to go to the new district. They had seen "flash-in-the-pan" new districts come and go, and, in addition, the claim recording fee in Canada was $\$ 15$ compared to $\$ 2$ in Alaska territory. The claim size in Canada was also smaller. When it became apparent that the Klondike was "for real," many of the miners did move up river to the new district, and the town of Fortymile was almost deserted during the winter of 1896-97. Although many miners left their claims in the Fortymile District for the Klondike, most returned within 1 or 2 years. Most of the Fortymile District's rich placers had been located by the turn of the century (Naske, 1977). Wharton (1972) related numerous interesting and often humorous anecdotes about the early history of the area in his chapter on "Fortymile, the first stampede town," and Berton (1958) included a scholarly account of the influence this community had in the subsequent mining history of the Yukon and interior Alaska. Wright (1976) gave interesting and well-documented accounts of the early life and times at Fortymile City. Selina Bompas, wife of the Right Reverend William Bompas, First Bishop of the Yukon, gave a very vivid account of her life and benevolent work with the Indians and miners at Fortymile City during the 1890's (Archer, 1929). More recently, Ann Ayer related her experiences while she and her husband lived at Steele Creek and prospected along the Fortymile River in the 1940's (Ayer, 1946), and, just published is Michael Gates' (1994) informative book, "Gold at Fortymile Creek," which tells the story of the early pre-Klondike search for gold in the upper Yukon River basin.

Though no one struck it rich in the Fortymile, the region has had a continuing appeal. Long after the boom at Circle and the stampede to the Klondike, the Fortymile

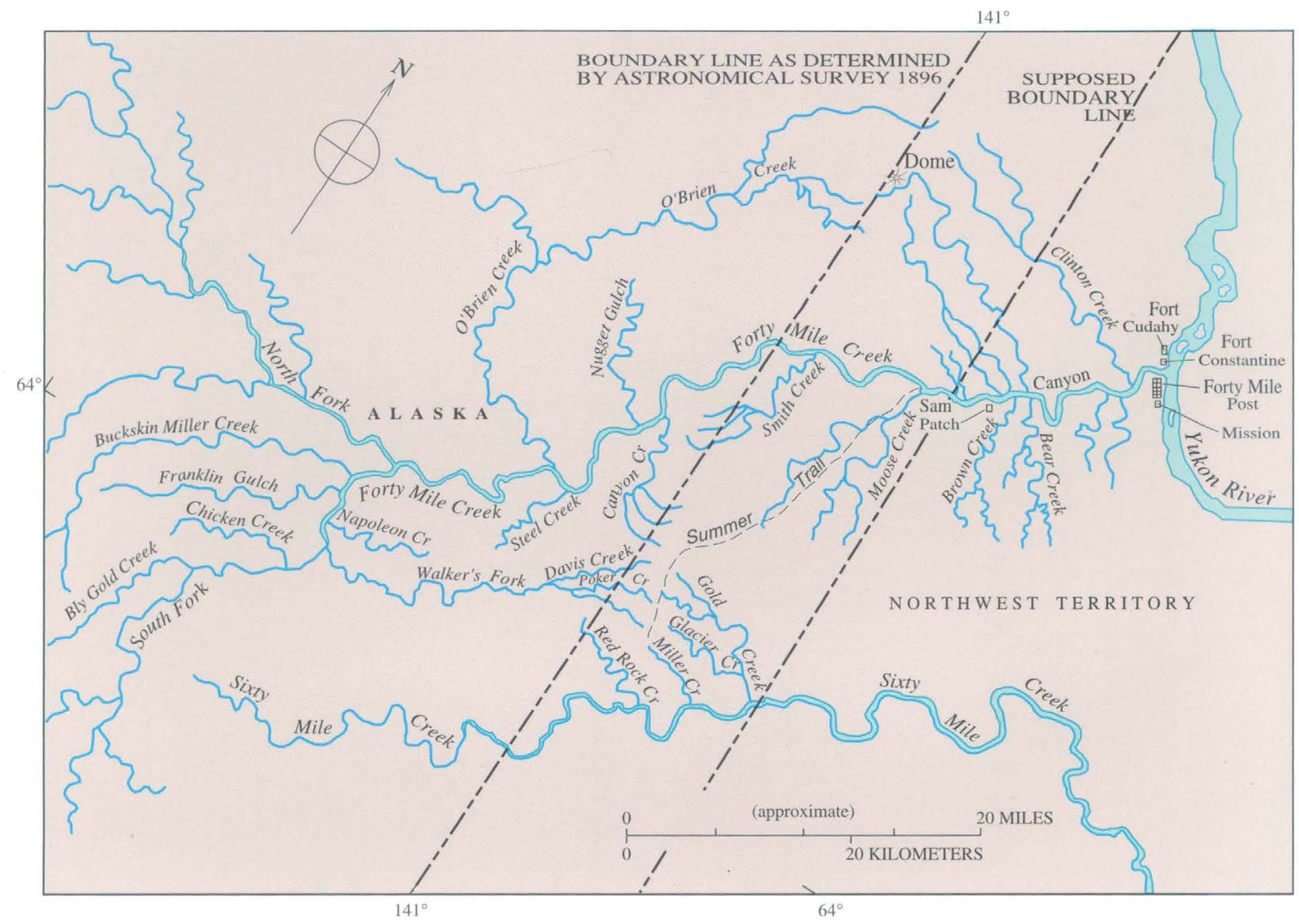


region continued to draw prospectors and miners content with a moderate return for hard work (Wharton, 1972). Fortymile, though small compared to the subsequent finds at Circle, Dawson, and Nome, will always be remembered in the legends and stories of the sourdoughs as the first rush. Fortymile was certainly one of the most colorful gold rush towns. It served the needs of the nearby Fortymile Mining District-as Circle City did for the Birch Creek District and Dawson did for the Klondike. Unlike Circle City and Dawson, however, Fortymile is now abandoned, and it is reachable only by boat or foot trail. Trees; grass, and fireweed are quietly reclaiming the few remaining buildings at this picturesque, pastoral site at the junction of the Fortymile and Yukon Rivers. It is a delightful place to visit and imagine the spirit and excitement of 100 years ago. The site was recently proclaimed a national monument by the Canadian Government.

\section{Previous Work}

Samuel Dunham (1898) wrote one of the earliest accounts of the discovery and subsequent development of mining in the Fortymile District. He was a special investigator and statistical expert for the U.S. Department of Labor, and his official report on labor and living conditions in the Alaska gold fields is one of the little known classics of gold rush literature. Dunham's report includes one of the first published geographic maps of the District showing the mistaken position of the Alaska-Canada boundary (fig. 4).

Spurr (1898) presented a rather detailed account of the happenings in the upper Yukon River valley just prior to the gold discovery in the Fortymile area, a short description of the gold discovery, and a rather extensive description of the geology of and mining on the major placer-rich creeks in the Yukon District. The report contains the first published geologic maps of the area, a map of a part of the Fortymile Creek showing the "...relation of ancient and present valleys," and provides an important historical perspective. A good discussion of the mining history and gold production of the Fortymile District in the 20th century can be found in The Northern Engineer (Naske, 1977). Short papers by U.S. Geological Survey geologists were concerned primarily with the conditions of mining throughout the District-these reports were written by Prindle (1905, 1908, 1909), Ellsworth and Parker (1911), Brooks (1916), Porter (1912), and Ellsworth and Davenport (1913). John Mertie visited the Fortymile District in 1928 and 1936 (Mertie, 1982), and his subsequent publication (1938) remains the most detailed and definitive on the placer geology and mining. His report on the bedrock geology in the Yukon-Tanana region (1937) is important and still useful.

More recently, Cobb's (1973) bulletin is useful for its broad overview of all placers throughout Alaska. Foster's geologic maps of the Eagle quadrangle at a scale of 1:250,000 (1976) and Eagle A-1 and A-2, scale 1:63,360 (1969), represent the best mapping to date. Foster (1992) and Foster and others (1987) reports are good up-to-date discussions of the terranes, general geology, and mineral resources of all of east-central Alaska.

\section{ACKNOWLedgments}

I would like to thank the courteous miners in the Fortymile River area who permitted access to their claims, allowed samples to be collected, and cooperated in the various phases of my work for this publication. Lynn Purdy allowed me to stay at her historic home in Chicken during parts of three summers and the Taylors on O'Brien Creek provided a delightful base to work from both for me and my helicopter pilot during the final summer field season. I am grateful for their hospitality. 


\section{GEOLOǴY}

Creeks containing both mined and unmined gold-bearing gravel are shown on plate 1. Bedrock units, somewhat simplified, and surficial deposits (in addition to creek gravels) are also shown on plate 1 . Gold values, where given, are calculated at the $\$ 350$ per ounce rate.

\section{BEDROCK}

East-central Alaska is made up of several accreted terranes (Jones and others, 1984) composed of rocks having continental, oceanic, and possibly island-arc affinities. The Fortymile region is part of a larger area referred to as the Yukon-Tanana region (Mertie, 1937), the Yukon-Tanana Upland (Foster, and others, 1973), and the Yukon Crystalline Terrane (Tempelman-Kluit, 1976; Churkin and others, 1982). It is primarily a terrane of quartzitic, pelitic, calcic, and mafic metasedimentary rocks that have been extensively intruded by Mesozoic and Cenozoic granitic rocks and minor amounts of intermediate and mafic rocks (Foster, 1992). Mertie (1937) described the geology and stratigraphy of the rocks in east-central Alaska and included many of the metamorphic rocks in the now-abandoned Precambrian Birch Creek Schist. In reconnaissance geologic mapping by Foster and others (1987), the metamorphic rocks were grouped into mappable rock units largely on the basis of lithology and metamorphic grade. The subterrane that includes most of the rocks in the Fortymile region, the Y4 subterrane (Foster and others, 1987) and the Taylor Mountain terrane or subterrane (Dusel-Bacon and Hansen, 1991, 1992), consists primarily of quartz biotite gneiss, marble, schist, quartzite, and amphibolite metamorphosed to the amphibolite and epidote-amphibolite facies, and intruded by dikes and plutonic rocks (Foster and others, 1987, Foster, 1992). Ultramafic rocks of the Seventymile terrane are present as discontinuous outcrops where they have been thrust upon, and imbricated with, older metamorphic rocks in the Fortymile area. Tertiary(?) to Paleozoic(?) igneous rocks intrude older metamorphic rocks. Small areas of Tertiary sedimentary and volcanic rocks overlie older igneous and metamorphic rocks. The metamorphic rocks have been deformed into tight asymmetric folds. Foliation is fairly well developed in the gneisses. Fold axes have an average trend of $\mathrm{N} 50^{\circ} \mathrm{E}$ and generally plunge less than $20^{\circ}$ northwest or southeast. A second generation of folding produced open folds with axes trending northsouth (Foster and others, 1987).

Five bedrock units are shown on plate 1 . These map units represent some lumping of lithologically similar units from the Foster (1976) map. Contacts were transferred with only slight modifications from the map of Foster (1976) (scale 1:250,000) to the 1:63,360-scale quadrangle maps used for the compilation of plate 1 . 


\section{GNEISS, SCHIST, AMPHIBOLITE, AND MARBLE}

Much of the southeast quarter of the Eagle quadrangle is underlain by gneiss, schist, amphibolite, and marble (Foster, 1976). Throughout east-central Alaska this rock unit is almost exclusively restricted to this part of the Eagle quadrangle, an area that is also rich in placer gold. The unit typically consists of medium- to coarse-grained quartz-amphibole-biotite gneiss, quartz-biotite gneiss, amphibolite, gray, white, and pink marble, greenstone, graywacke, chert, phyllite, and quartzite. Many of the greenstones appear to have been derived from mafic tuffs and lavas. The greenschists and amphibolites were probably derived from pelitic protoliths. Chert-like rocks may have been derived from siliceous volcanic rocks (Foster, 1969). Some rocks are highly garnetiferous. The metamorphic grade may be as low as upper greenschist facies, similar to the rocks in the Chicken, Purdy Quartz Mine, and Boundary areas (Foster, 1976). The rocks also include middle to upper amphibolite facies (Foster and others, 1987). The gneiss and schist are recrystallized, have excellent foliation, and original sedimentary or igneous structures have been obliterated. Foliation and compositional layering is deformed into tight asymmetric, locally isoclinal folds. Along Wade Creek the foliation of the gneiss and schist is commonly nearly horizontal and parallel to the compositional layering.

The major regional metamorphism and accompanying deformation of these rocks is probably Late Triassic to Middle Jurassic in age. Granitic intrusive activity was probably synchronous with the metamorphism.

The age of these rocks is poorly known, but it is con-

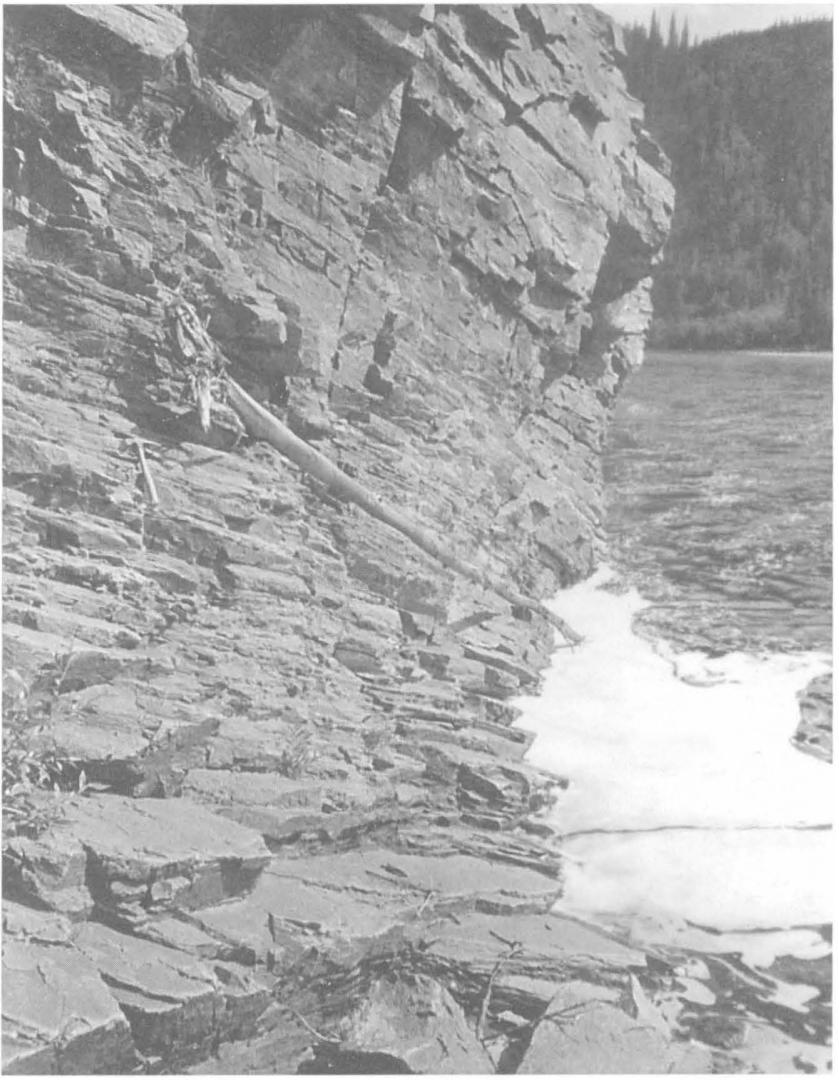
sidered to be Paleozoic on the basis of contained poorly preserved crinoid columnals (Foster, 1976) and regional stratigraphic relations.

The blocky outcrops of this unit (fig. 5) weather to rock slabs and elongate cobbles and boulders, which are the predominant clast shapes in the creek gravel.

\section{ULTRAMAFIC ROCKS}

This unit is present in only two areas on the map (pl. 1), in the extreme southeast corner and as a very small outcrop in the north-central part of the map area. The peridotite in the southeast corner covers approximately three square miles (eight square kilometers). It is a gray, greenish-gray, and pinkish-gray serpentinized peridotite. The rocks are mainly Paleozoic and Mesozoic partly serpentinized harzburgite and dunite, and they include minor amounts of clinopyroxenite (Foster and others, 1987). There are many ultramafic rock masses in the southeast corner of the study area that are too small to show on the map.

\section{IGNEOUS ROCKS}

Paleozoic(?), Mesozoic, and Tertiary(?) igneous rocks intrude older metamorphic rocks and are exposed at several places in the area shown on plate 1. A part of the Taylor Mountain batholith crops out in the southwest part of the Fortymile area. It is mostly medium-grained, equigranular granite, but it also includes granodiorite and diorite. The margin of the batholith is irregular with many dikes extending into the surrounding country rocks. Mapping a precise 
contact is difficult, particularly where the country rocks have been altered to hornfels and partly absorbed into the igneous mass (Foster, 1969). Potassium-argon dating indicated an age of approximately $180 \mathrm{Ma}$ for the Taylor Mountain batholith (Foster and others, 1987).

Other mapped igneous rocks are primarily quartz monzonite, granodiorite, granite, diorite, aplite, alaskite, and pegmatite, which are Mesozoic and Tertiary(?) in age. In the northeast corner of the area shown on plate 1 is a dark greenish black, coarse- to fine-grained metagabbro with metadiabase and metahornblendite, probably late Paleozoic or early Mesozoic in age (Foster, 1976). A discussion of gold mineralization related to these rocks will be presented in the "Gold Source" section.

\section{SANDSTONE, CONGLOMERATE, SILTSTONE, SHALE, AND COAL}

Unmetamorphosed nonmarine sedimentary strata are present at three localities in the Fortymile area: the Chicken Creek, Napoleon Creek, and Squaw Gulch-Baby Creek drainages (pl. 1). They are most likely Tertiary in age and of minor extent, because they were likely deposited in small, disconnected basins. Some are closely associated with volcanic rocks that include considerable amounts of tuff. They have been folded and where bedding can be detected, dips as much as $60^{\circ}$ have been measured.

In the Chicken Creek area, the sedimentary rocks are mostly covered by alluvial deposits, placer mine tailings, and basalt. Basalt cuts the sedimentary rocks in the Chicken Creek area. Bucketline dredges working along Chicken Creek have brought up pieces of the underlying sedimentary rocks. Rock types are dominantly tuffaceous sandstone, ferruginous sandstone, conglomeratic sandstone, shale and tuffaceous shale, and lignitic coal. Cobbles and boulders of a black glassy siliceous tuff contain abundant plant fossils that are late Tertiary or early Pleistocene in age. Leaves of Metasequoia glyptostroboides Hu and Cheng and Alnus evidens (Hollick) Wolfe and poorly preserved palynomorphs, including the genera Carya, Ulmus, Alnus, Acer, Abies, Juglans, Tilia, Tsuga, Larix?, and Osmunda, suggest an early Tertiary age (Foster, 1969) for the sedimentary rocks near Chicken. Because of the poor exposures of the sedimentary rocks in the Chicken area, no information is available on either the thickness of the beds or their structural relation. Mertie (1937) claimed that "a 35-foot (10.6-meter) shaft near Chicken disclosed 22 feet (6.7 meters) of coal, in a vertical position, but neither the top nor the bottom of the seam was seen." A low-grade subbituminous coal was mined in the Chicken area from 1936 to 1938. It was used as a fuel for the steam-powered Cowden and Walker Fork dredges. It was, however, a poor fuel because it "clinkered up" the boilers (Haynes, 1976). The remains of old scaffolding at mile 65.4 (kilometer 105.2) on the Taylor Highway could still be seen in 1968 marking the site of the abandoned mine (Foster and Keith, 1969).

Near the mouths of Walker Fork and Napoleon Creek, a well-indurated conglomerate and breccia is overlain by sandstone, shale, lignitic coal, arkose, wacke, and siltstone. Basalt overlies the sedimentary rocks here. The basal conglomerate contains boulders as much as 6.5 feet ( 2 meters) in diameter. Clasts are composed of angular to well-rounded gneiss and schist, greenstone, green and gray phyllite, quartzite, chert, black shale, granite, and basalt. The conglomerate ranges from about 15 to 100 feet ( 5 to 30 meters) in thickness. The total thickness of the sedimentary rocks in the vicinity of Napoleon Creek is over 390 feet (120 m) (Foster, 1969).

Near Baby Creek, coarse conglomerate with interbedded sandstone and shale is predominant. The conglomerate is made up of angular boulders as much as $1 \mathrm{~m}$ in diameter. Clasts are quartz-biotite gneiss, dark-gray mafic gneiss, and granite. Pollen from conglomerate and sandstone near Baby Creek indicates a late Tertiary age for these rocks. Thickness ranges from just over 3 feet to $325+$ feet (1 to 100+ meters) (Foster, 1969, 1976).

\section{BASALT}

Basalt is present only near Chicken, Stonehouse, Ingle, and Napoleon Creeks (pl. 1). It is dark greenish black and weathers to brown. This Tertiary(?) basalt is commonly fractured, 
shows spheroidal weathering, and is cut by calcite veinlets. It crops out beneath terrace gravel along Mosquito Fork, Napoleon Creek (fig. 6), and on benches along Stonehouse Creek where miners washed and stacked the overlying gravel. It also underlies much of the lower Chicken, Stonehouse, and Myers Fork drainages. Near Chicken, the basalt unconformably overlies granodiorite and Tertiary sedimentary rocks, and a basalt dike cuts across upper Chicken Creek.

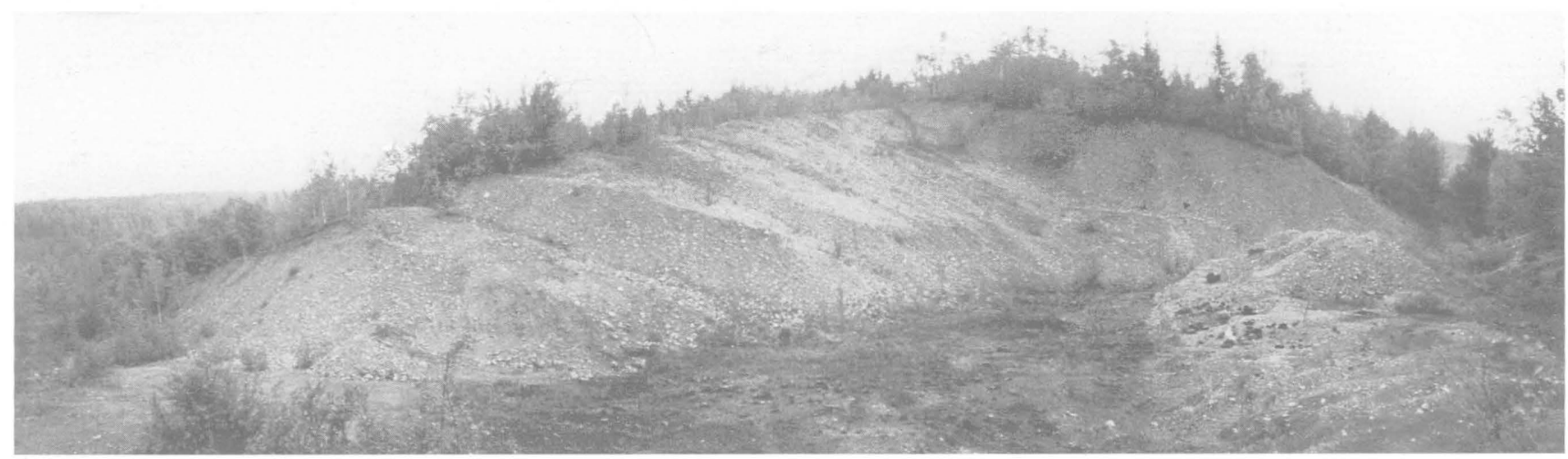

\section{High terRace GRavels}

Terrace gravels as high as 590 feet (180 meters) above present creeks and rivers are present in the mapped area (pl. 1). They are particularly evident along the Fortymile River, and its two forks, the South and North Fork, but are also present along the Mosquito Fork, O'Brien Creek, Walker Fork, and Alder (northern part of map area), Buckskin, Napoleon, Chicken, Stonehouse, and Dome Creeks (pl. 1). The gravels are present as remnants of what was originally a continuous river floodplain deposit and have been partly removed by stream erosion. The gravels cap terraces by present-day streams because the Fortymile River and its tributaries have been entrenched to a maximum depth of 590 feet (180 meters). The gravels are unconsolidated and contain well-rounded to subrounded boulders as much as 1.6 feet (0.5 meters), but .3- to .6 foot- ( 0.1 - to $0.2-\mathrm{m})$ - diameter boulders are more common; the matrix is sand and granules and contains lenses and beds of sand and silt. The gravels are generally well sorted but poorly stratified, however, local stratification and imbrication are present. The clasts are derived from the local rock types exposed in the present drainages, and schist and quartzite are the predominant clast types; granitic and white quartz clasts are also common (table 1). The gravels are frequently stained orange by limonite and locally cemented. The high terrace gravels commonly exist as only a very

Table 1. Pebble counts expressed in percentages for selected localities in high terrace gravels, Fortymile Mining District, east-central Alaska

[Location numbers (in parentheses) are keyed to plate $1 ;-$, not present]

\begin{tabular}{|c|c|c|c|c|c|}
\hline Locations & & & Rock types & & \\
\hline & Quartz & Quartzite & $\begin{array}{c}\text { Granite and } \\
\text { aplite }\end{array}$ & $\begin{array}{l}\text { Schist and } \\
\text { gneiss }\end{array}$ & $\begin{array}{l}\text { Greenschist } \\
\text { and other }\end{array}$ \\
\hline Between Myers Fork and Ingle Creek (1) & 20 & 40 & 32 & 6 & 2 \\
\hline Bench above Stonehouse Creek (2) & - & - & 74 & 2 & 24 \\
\hline Lost Chicken Creek (3) & 4 & 22 & 46 & 12 & 16 \\
\hline Taylor Highway near Walker Fork (4) & 8 & 44 & 4 & 44 & - \\
\hline Terrace above Napoleon Creek (5) & 8 & 34 & 28 & 30 & - \\
\hline Terrace above Fortymile River (6) & 30 & 46 & 16 & 6 & 2 \\
\hline Dome Creek terrace ( 7 ) & 32 & 46 & - & 22 & - \\
\hline
\end{tabular}

Figure 6 HIGH TERRACE GRAVELS, 130 feet (40 meters) thick, resting on basalt exposed on north side of $\mathrm{Na}$ poleon Creek approximately 560 feet (170 meters) above the creek. High terrace gravels from this locality have yielded over 1,300 ounces of gold. 
thin veneer (about 3 to 6.5 feet or 1 to 2 meters) on bedrock at numerous locations where the gravels were exposed by hand digging. However, gravel thicknesses of over 130 feet (about 40 meters) are present in the Napoleon, Dome, and parts of $\mathrm{O}^{\prime}$ Brien Creek drainages. Permafrost is present within 3 feet ( 1 meter) of the ground surface on all high terraces.

Placer gold is locally present in the high terrace gravels. Gold fragments as much as .11 inches (3 millimeters) in diameter were panned from the high terrace gravels on the south side of Buckskin Creek, and a 44-pound (20-kilogram) sample of the high terrace gravels on the north side of Dome Creek yielded 10 to 20 gold colors. However, no gold was observed in several panned samples from the high terrace gravels along O'Brien Creek. The terrace, which is about 560 feet ( 170 meters) above Napoleon Creek, yielded 1,300 ounces of gold from an area not much larger than $1 / 4$ acre ( 0.10 hectare) (fig. 6). Gravels on this terrace possess subrounded cobbles and boulders as much as 1.6 feet ( 0.5 meters) in diameter with a high percentage of granite clasts. The gravels are approximately 130 feet (40 meters) thick and rest on Tertiary sandstone, siltstone, and basalt. Lost Chicken Hill is the location of another high terrace (roughly 260 to 300 feet or 80 to 90 meters above Chicken Creek) with gold-bearing gravels. Gold was found here at a depth of 33 feet (10 meters) and mined by drifting (Mertie, 1938) in the early 1900's and by surface methods on and off to the present. High terrace gravels along both Dome and Stonehouse Creeks have been mined intermittently, and unmined gold-bearing gravel terraces are known along Chicken Creek (Mertie, 1938). The high terrace gravels are used in road construction and repair where they are present in close proximity to existing roads-as near Chicken, near the mouth of Walker Fork, and along the lower 7.4 miles (12 kilometers) of O'Brien Creek (fig. 7).

The high terrace gravels would seem to be a potential

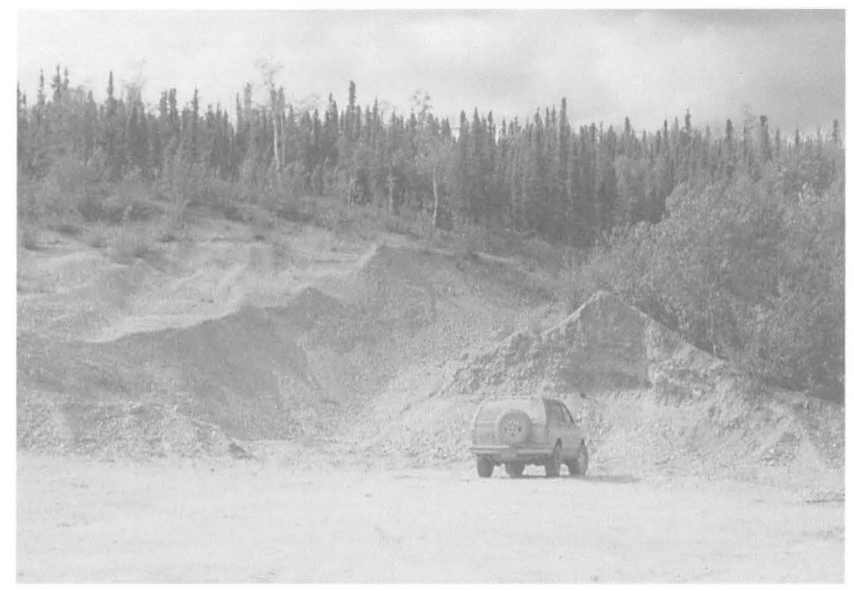
source of unmined placer gold. Because of the difficulty of both prospecting and mining these gravels, comparatively little work has been done on them. The lack of road access eliminates the commonly used and reliable method of sampling — churn drilling. Likewise, widespread tree cover prevents the landing of a helicopter to gain easy access. Some of these high terrace gravels would be most effectively prospected from a small boat. Arduous, steep, foot traverses would be required to gain access to the terraces from the rivers and creeks. Hand digging would be necessary to expose the lower gravel contacts to obtain a sample (50 to 100 pounds, 22 to 44 kilograms) to haul back to the creek for panning. Each terrace-gravel outcrop would need to be sampled at frequent intervals along the lower contact with

Figure 7 HIGH TERRACE GRAVELS EXPOSED IN BARROW PIT on west side of road to Eagle along O'Brien Creek near mouth of King Creek in east-central Alaska. Gravel, composed of well-rounded pebbles and cobbles is well sorted. Granule, sand, and silt beds are rare; thickness is 33 to 50 feet (10 to 15 meters). bedrock, because gold concentration is spotty and generally present in small pockets. To mine the once-located gold-rich high terrace gravels, either the frozen gravel would have to be thawed and transported down to the creek or the water from the creek would have to be pumped to the deposit, which could be as much as a 180 -m vertical lift. It is not surprising then that these deposits have rarely been looked at or sampled (Yeend, 1990).

A volcanic ash bed (tephra) in the peat and silt section above the gold-rich high terrace gravels at Lost Chicken Creek has been dated at 1.7 to $2.6 \mathrm{Ma}$ (Naeser and others, 1982). It is called the Lost Chicken tephra bed. Both zircon microphenocrysts and glass shards were dated. The dated samples were collected about 56 feet (17 meters) below the top of a 82-foot-thick (25-meter-thick) section of organic silts exposed at mile 69 on the Taylor Highway, east of the road (figs. 8,9). This tephra date would require that the goldbearing high terrace gravel here is at least as old as Pliocene as originally suggested by Mertie (1938). The high terrace gravels here may correlate, at least in part, with the White 
Channel gravel in the Klondike area of the Yukon (Morrison and Hein, 1987; Naeser and others, 1982), which is the principal placer gold-producing unit there. In the Yukon, the White Channel deposits are probably of Pliocene and early Pleistocene age and crop out as gravel terraces on bedrock benches. In the Fairbanks Mining District, the principal placer units are the Cripple Gravel, a brown auriferous gravel of late Pliocene and (or) early Pleistocene age, and the Fox Gravel, a tan auriferous gravel of early or middle Pleistocene age (Péwé, 1975). The high terrace gravels in the Fortymile area probably correlate with at least part of the Cripple Gravel.

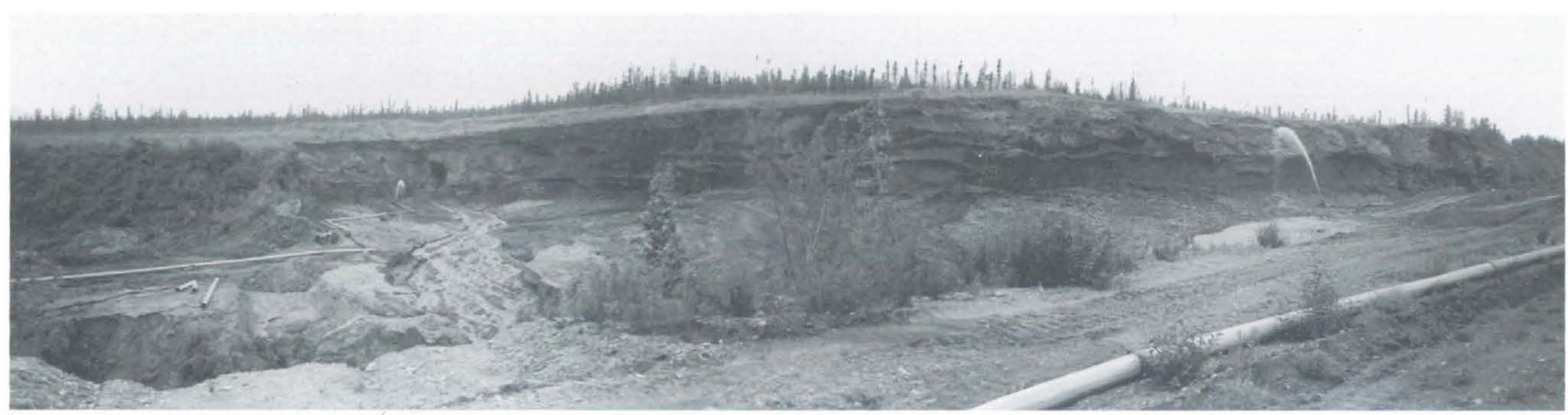

\section{GOLD-BEARING GRAVEL}

Gold-bearing creek gravels are present throughout the Fortymile River region. They exist as both contemporary floodplain and older, low-level terrace deposits along some valley margins. Included within this gravel unit are lenses, beds, and horizons of sand, silt, and clay. These are generally thin and not extensive.

In addition to showing the outlines of the gravel deposits in the valley bottoms, I have attempted to show the outlines of the mined parts of the gravels (pl. 1). In many cases, the same gravels have been repeatedly washed in successive mining operations. Additional information on the gravels, including gold values, is found in the sections that discuss the geology and mining of the individual creeks and rivers.

\section{UpPer AND LOWER CONTACTS}

The gravels rest with pronounced angular unconformity on dipping eroded quartzites, quartzitic schists, amphibolite, marble, gneiss, phyllite, and granites. Near the Chicken and Napoleon Creek drainages, the gravel rests on eroded Tertiary basalt and a variety of sedimentary rocks ranging from coal to conglomerate and shale. A weathered decomposed zone developed on the bedrock, particularly the granite and basalt, is rarely present. Rock cleavage, jointing, and associated fractures are common within the metamorphic rocks. These structures have acted as natural traps for gravel clasts and detrital gold particles. Miners typically tear up a 3- to 6.5-foot (1- to 2- meter) thickness of the old creek floor when mining to effect a more complete recovery of the entrapped gold.

Dark-colored organic silt and muck, 3 to 10 feet (1 to 3 meters) in thickness, commonly overlie the gold-bearing gravels, particularly along the creek-valley margins. These are, in part, overbank deposits and fine-grained colluvium derived from the adjacent steep-sided slopes. It is almost always ice-rich and perennially frozen. This material is exposed by scraping off the overlying tundra, allowed to thaw, and stripped from the underlying gravel prior to mining. Only the most active parts of the creek floodplain are free of this fine-grained organic-rich overburden. Because most of the creek gravels have been mined at least once, the only ice-rich muck remaining is that on the extreme borders of the creeks, areas which have escaped mining.
Figure 8 FROZEN MUCK BANKS OF MINE PIT on the south side of the Lost Chicken Creek valley just west of the Taylor Highway in eastcentral Alaska. Pipe in foreground carries water to hydraulic monitors in the background that are used to thaw frozen muck.

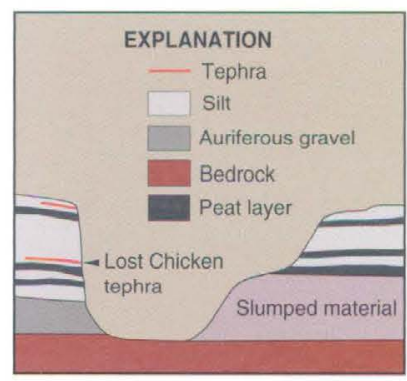

Figure 9 DIAGRAMMATIC CROSS SECTION SHOWING LOST CHICKEN TEPHRA BED, which is situated about 26 feet ( 8 meters) above valley floor of Lost Chicken Creek. Total height of the section is about 82 feet ( 25 meters). Modified from Naeser and others (1982). 


\section{Lithology AND TEXTURE}

Although varying slightly from creek to creek, the lithology and textures of the goldbearing gravels are remarkably uniform. They are typically gray to brown, unconsolidated, moderately well sorted and stratified, and generally dominated by clasts of quartz-mica schist, quartzite, amphibolite, gneiss, marble, and granite. Because schistose metamorphic rocks predominate, most of the boulders and cobbles are rectangular and slabby with rounded edges. Boulders are generally less than 8 inches (20 centimeters) in diameter; however, some are larger. The matrix is typically a coarse gray-brown sand and includes minor amounts of silt and clay. Organic material in the form of whole to macerated twigs, leaves, and logs is present as isolated pockets in the gravels. Pebble counts and other characteristics of the gravels of individual drainages are discussed in the sections on individual drainages. Results of the studies of heavy minerals and detrital gold are discussed under the "Heavy Minerals" section.

\section{THICKNESS AND AgE}

The gold-bearing alluvial gravel, where restricted to narrow valleys, is usually 6.5 to 10 feet ( 2 to 6 meters) thick. Where streams debouch from the valleys and have built up fans, the gravel is thicker. The overlying organic-rich tundra and muck is commonly 3 to 6.5 feet ( 1 to 2 meters) thick, but it is occasionally thicker on the valley margins where large amounts of soil and fine-grained colluvium have accumulated from the steep side slopes.

It would seem that the gold-bearing gravels are no older than late Pleistocene (less than 40,000 years B.P.), and many are no older than Holocene (less than 10,000 years B.P.) on the basis of youthful morphology, topographic position in valley bottoms and as low terraces along modern streams, and the youthful soil development on the gravels. Clasts are fresh, with little, if any, noticeable weathering. Vertebrate bones are rarely present in the frozen muck overlying the gravels. These are of animal types similar to those found in late Pleistocene deposits in other areas of Alaska.

\section{Colluvium}

Unsorted to very poorly sorted gravel, sand, silt, and clay are sporadically present within and along the margin of stream valleys. This Colluvium unit includes talus rubble and mixed alluvium and debris-flow material as end members. It may possess horizons of water-washed detritus, but it is largely composed of boulder-to clay-size material that has accumulated by gravity movements near the bases of steep slopes, commonly in the shape of fans-colluvial fans. Boulders are generally angular to subangular in shape. Vegetative organic matter is frequently incorporated in the unit, and permafrost is generally present as well as massive ice lenses and wedges. An organic mat, 1.5 to 10 feet ( 0.5 to 3 meters) thick, commonly caps the unit and acts as an effective insulation to melting of the permafrost. Where this unit has been disturbed or exposed by excavation, melting and subsequent slumping and flowage are common.

Geologic processes such as mass wasting are generally poor concentrators of heavy minerals, especially gold. Therefore, when gold is found in colluvial deposits in minable amounts, gold-rich alluvial deposits were probably somehow incorporated into the colluvium during downslope movement. I suspect that gold-rich bench gravels along the valley sides in the Fortymile area have been at least a partial source of the gold in the colluvium. The north side of the Walker Fork valley contains discontinuous, low gravel-capped terraces, which are being eroded, primarily by mass wasting. Much of this material is mapped as colluvium (pl. 1), some of which is gold-bearing; however, values are spotty.

The narrow valleys of Franklin, Ingle, Younger, Poker, Davis, Baby, Stonehouse, Squaw, Dome, Uhler, and Fortyfive Pup Creeks and Myers Fork contain colluvium, although many 
of the outcrops are too small to show at the scale of plate $1(1: 63,360)$. Most of these deposits have been mined for gold, although a few small creek-margin deposits are unmined.

Much of the unconsolidated gravels within the major drainages of the Fortymile River, South Fork, North Fork, and Mosquito Fork are mapped as colluvium (pl. 1) because they are largely coarse-grained and unsorted. However, within the mapped colluvial unit is alluvium, both floodplain and fan deposits. The colluvial deposits along these drainages are discontinuously gold-bearing, and values are exceedingly variable. The uplands in the Chicken Creek drainage are mantled with colluvium composed of reworked silt and the high terrace gravel.

Because of the high ice content of these deposits, some type of thawing plan is necessary before mining. Often this involves stripping off the overlying organic mat the year prior to mining, which allows natural solar insolation to initiate melting. Surface water is sometimes directed to flow over the deposit to aid melting and (or) high-pressure water jets are sprayed on the deposit to melt the low-value overburden, as well as the higher value deeper gravels. These deposits characteristically contain a high content of silt- and clay-size material, which complicates the thorough washing of the mined gravels and results in "dirty" effluent.

Minable deposits of locally occurring gold-bearing colluvium, too small to map at 1inch-to-mile scale, are present along the margins of other steep-sided, narrow placer-rich valleys and will be located and mined when, and if, the economic conditions are favorable.

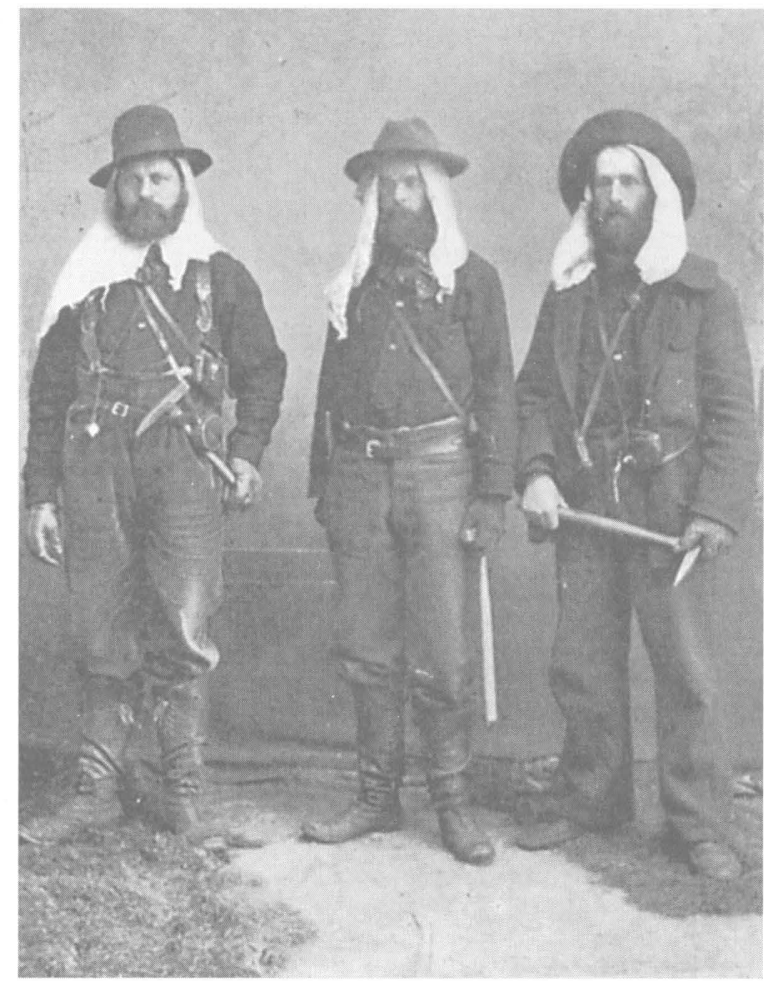

Yukon River geologic traverse in 1896. Geologists Frank C. Schrader. J. Edward Spurr, and Harold B. Goodrich pose outfitted for hard duty. Photographer unknown. 


\section{GOLD-RICH CREEKS AND RIVERS}

$\rightarrow-$

Because the local geology and mining conditions vary throughout the Fortymile District, each drainage will be discussed separately. Although many of the creeks and rivers are mined out, some contain enough gold to support small mining operations. The early and modern mining history, bedrock, unconsolidated deposits, valley morphology, gravel textures, lithology and thickness, production, and remaining resources for each drainage are discussed in a "best-guess" order of gold production, beginning with the richest.

\section{ForTyMile River}

The namesake for the Fortymile Mining District, the Fortymile River, was named by early prospectors, probably about 1886 , the year of the gold discovery in the district. The name was applied because the river mouth is about 40 miles (64 kilometers) below the former Hudson Bay Company post, Fort Reliance, on the Yukon River (Orth, 1967). The Fortymile River, as discussed herein, includes the main river from the Canadian border and the North Fork to the geographic feature termed The Kink. The South Fork will be treated in the "South Fork" section.

The gold discovery in the Fortymile District was on the Fortymile River (fig. 10), about 25 miles (40 kilometers) above the mouth, barely in Alaska. The lower 23 miles (37

Figure 10 VIEW TO EAST DOWN FORTYMILE RIVER, east-central Alaska. The river bar in the foreground on the north (left) side of the river is probable gold discovery site (in 1886) in the Fortymile Mining District. Discovery Creek comes in from north (left) in middle distance.

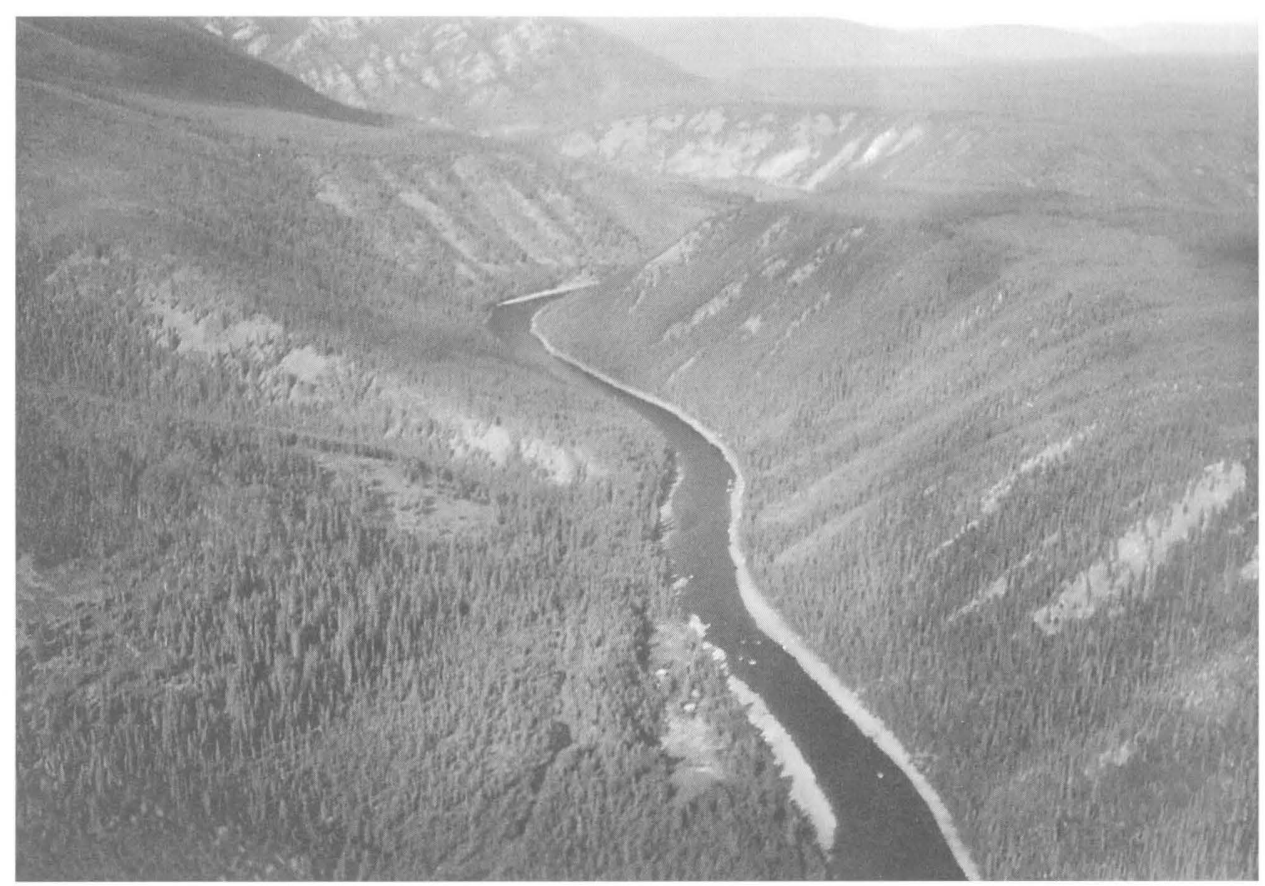


kilometers) of river is in Canada. The earliest mining in the district was on the bars of this river-Bonanza, Franklin, Discovery, Claghorn, and Madden Bars. A detailed description of the town of Fortymile is presented in the "Early History" section.

Ever since the gold discovery, mining has mainly been focused on the river bars, which are perennially enriched by floods that remove, resort, and redeposit alluvium and placer gold along the river. In the summer of 1890, miners attempted to turn a slough of the river near Bonanza Bar to uncover submerged gravel suspected of being rich in gold. In addition to the ubiquitous rocker used by almost all the early miners, a "china pump," a large wheel resembling the propulsion wheel of the old Mississippi stern-wheel river boats, was used to elevate buckets of water to sluice boxes. Recovering of 0.15 to 0.5 ounces of gold per miner per day was representative using these methods (Wells and Sherman, 1974). Discovery Bar is reported to have yielded approximately 4,700 ounces of gold in the early mining efforts. A bar opposite the mouth of Smith Creek is reported to have pro-

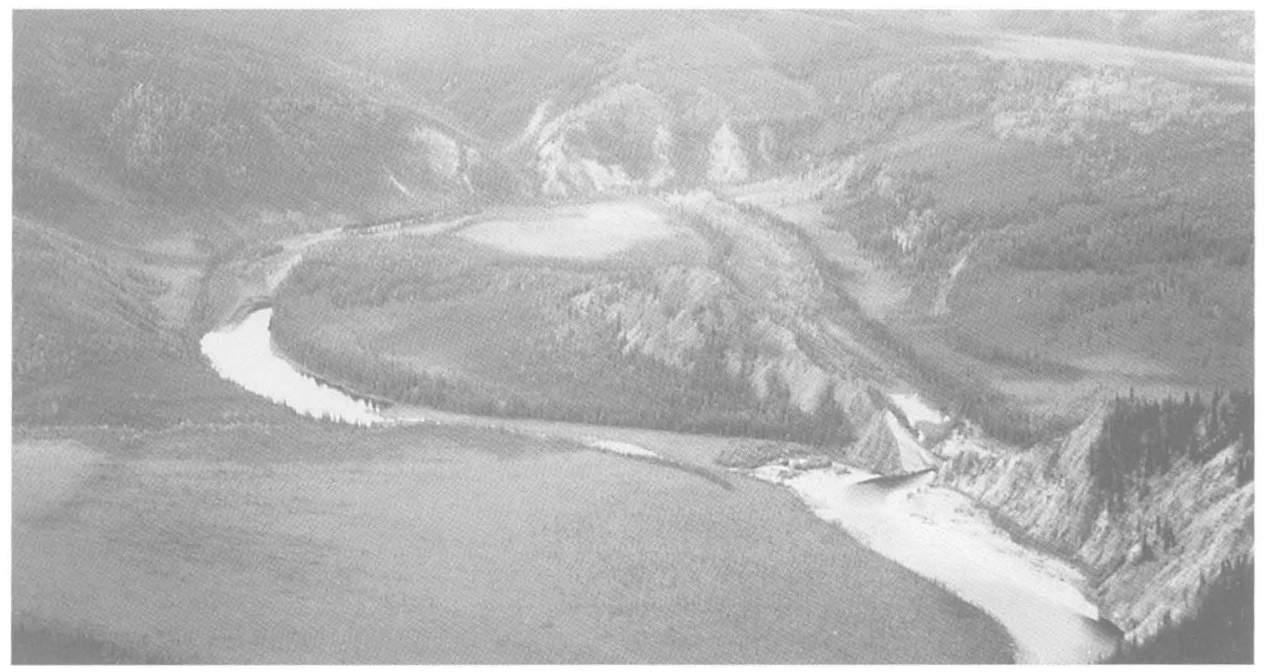

duced about 30,000 ounces of gold also during the early mining activity here (Prindle, 1909). In the early days, according to some sources, parts of the banks of the Fortymile River were so congested that a man could claim and work an area only as large as he could mark out with the tip of his shovel while standing in one place (Wilson, 1951).

Approximately 20 miles (32 kilometers) up the North Fork from its confluence with the South Fork is a curious point on the map called The Kink. It is a very recently unnatural abandoned meander of the river. It was created in 1900 when an English-backed company blasted away a 100-foot-high (30 meters-high) bedrock ridge. The blast changed the course of the river and laid bare the 2 3/4-mile-long (4.4-kilometer-long) abandoned river bed meander (fig. 11). The original width of the cut-off was only about 16 feet (5 meters), and at first only a small quantity of water flowed through it, but after a few hours the main body rushed through and soon worked out a channel over 39 feet (12 meters) wide (Prindle, 1905). The company had determined that the newly exposed gravels contained gold valued at approximately $\$ 9.00$ per cubic yard so they were intent on mining them. In 1901 while an attempt was being made to mine the gravels with horses and scoops, a rock slide occurred that covered the gravels after which the company abandoned the area (Scott, 1990).

Most of the Fortymile miners bought supplies in Dawson, Yukon Territory, and, during the winter months, used the frozen Fortymile River to transport their outfits with the aid of horsedrawn sleighs. During the winter of 1906-07, several hundred tons of dredge parts were shipped into the Fortymile District on the frozen river. One dredge operated near the International boundary on the Fortymile River and another worked Sourdough Bar 4 miles (6.4 kilometers) above the mouth, in Canadian territory (Naske, 1977). The
Figure 11 AERIAL VIEW OF ABANDONED MEANDER OF NORTH FORK OF FORTYMILE RIVER (eastcentral Alaska) at location known as "the kink." The river abandoned the meander when miners blasted a notch through the meander neck in 1900 with the intention of mining the newly exposed river bed. 
Figure 12 VIEW EAST DOWN FORTYMILE RIVER AT THE MOUTH OF STEELE CREEK eastcentral Alaska. The uninhabited Steele Creek townsite consists of several log cabins, some of which are still in good repair. The two-story log structure is the old combined roadhouse and post office, which was active from 1907 to 1951. This community was an important distribution point for placer mines along the Fortymile River. dredge operating on the Alaska side of the boundary about $1 / 2$ mile (.8 kilometer) below Moose Creek was equipped with 2.5 cubic-foot (.09 -cubic-meter) buckets and had a digging capacity of about 1,500 cubic yards (1,147 cubic meters) per 24 hours. The dredge worked on a bar where there was 8 feet (2.4 meters) of unfrozen gravel on bedrock (Prindle, 1908). It also worked on Moose Creek from 1909 to 1911 (Spence, 1996). This dredge was too small and lightweight to effectively handle the large boulders found at this locality, and consequently, it recovered little gold. Dredges operating at various times on the Fortymile River were not as productive as others in the Fortymile District. Most of the bars of the Fortymile had thin veneers of gravel with spotty values and would not have seemed to be good dredge ground. By 1914 the dredges had ceased operation; however, a customs station roadhouse at Moose Creek operated until 1962, when it burned.

Nugget Gulch, a small tributary of the Fortymile about 1.2 miles (2 kilometers) west of Bonanza Bar, is said to have produced several hundred ounces of gold in the late 1800's and early 1900's (Prindle 1905, 1909). The gold may have been reconcentrated from the high terrace gravel here. In the early 1890's George Carmack with his Indian wife, Kate, mined on Nugget Gulch. They had moderate success, but soon had mined all the gold on their claim and they left (Johnson, 1990). George Carmack several years later (1896) became famous as the discoverer of gold in the Klondike.

In 1912, 25 to 30 men were reportedly working the bars and low benches along the Fortymile river with rockers. The recovered gold was described as fine and flaky (Ellsworth and Davenport, 1913).

Steele Creek community, located at the confluence of Steele Creek and the Fortymile River, was an important distribution point for the placer mines along the Fortymile River from the mouth of the North Fork to the International boundary (fig. 12). Consisting of two cabins, a barn, an airstrip, and a combined post office and roadhouse active from 1907 to 1951, this community served as a central meeting place for the Fortymile miners (Couch, 1957).

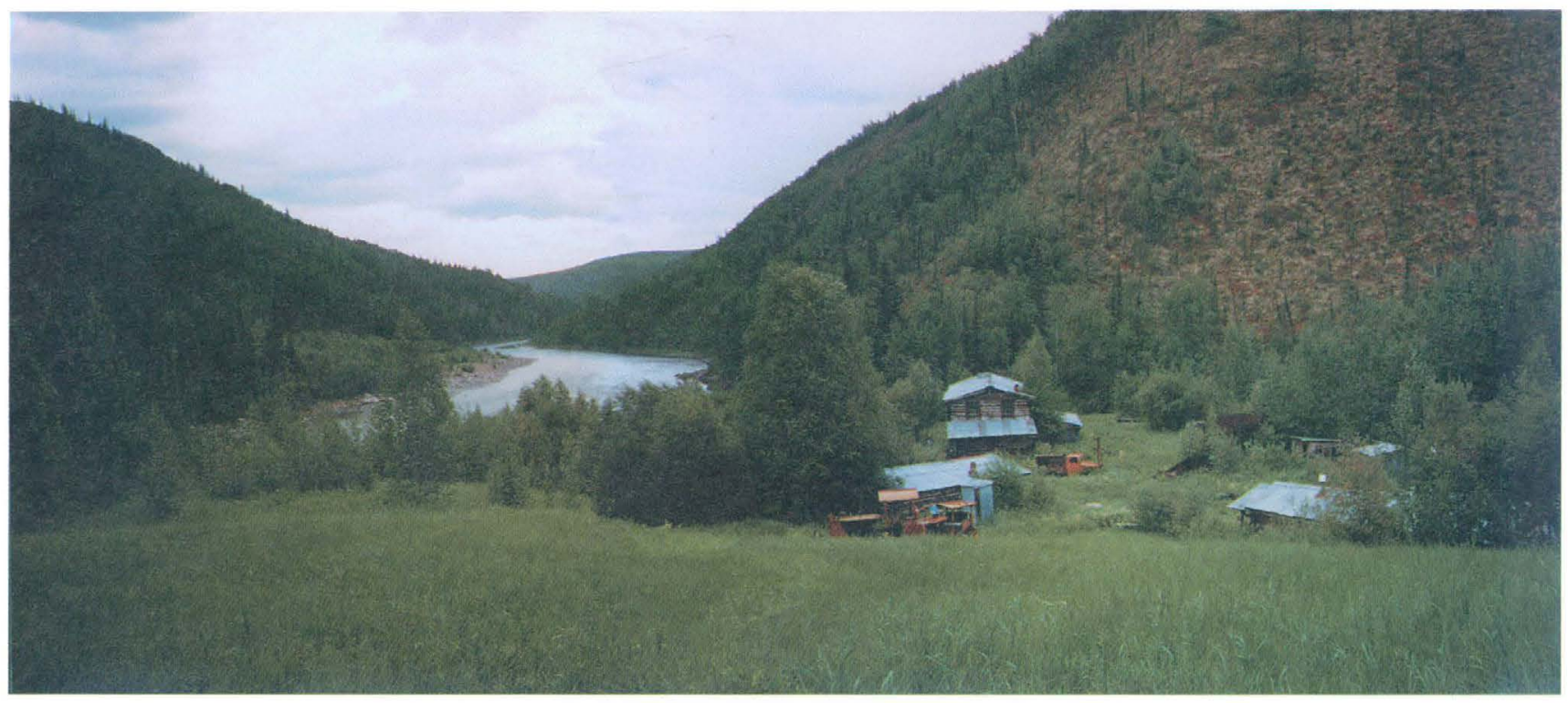

Winter mining took place occasionally along the Fortymile River. "Swansons Diggings" in the bed of the River was a winter operation (fig. 13); ice on the river was picked away and frozen gravel was thawed down to bedrock by an open wood fire. Most of the gold was found in the lowest gravel deposits just above bedrock. Mertie (1938) reported that 15 men were engaged in small-scale mining along the Fortymile River in 1937. They shoveled gravel into sluice boxes and used rockers and small-scale hydraulic methods. 

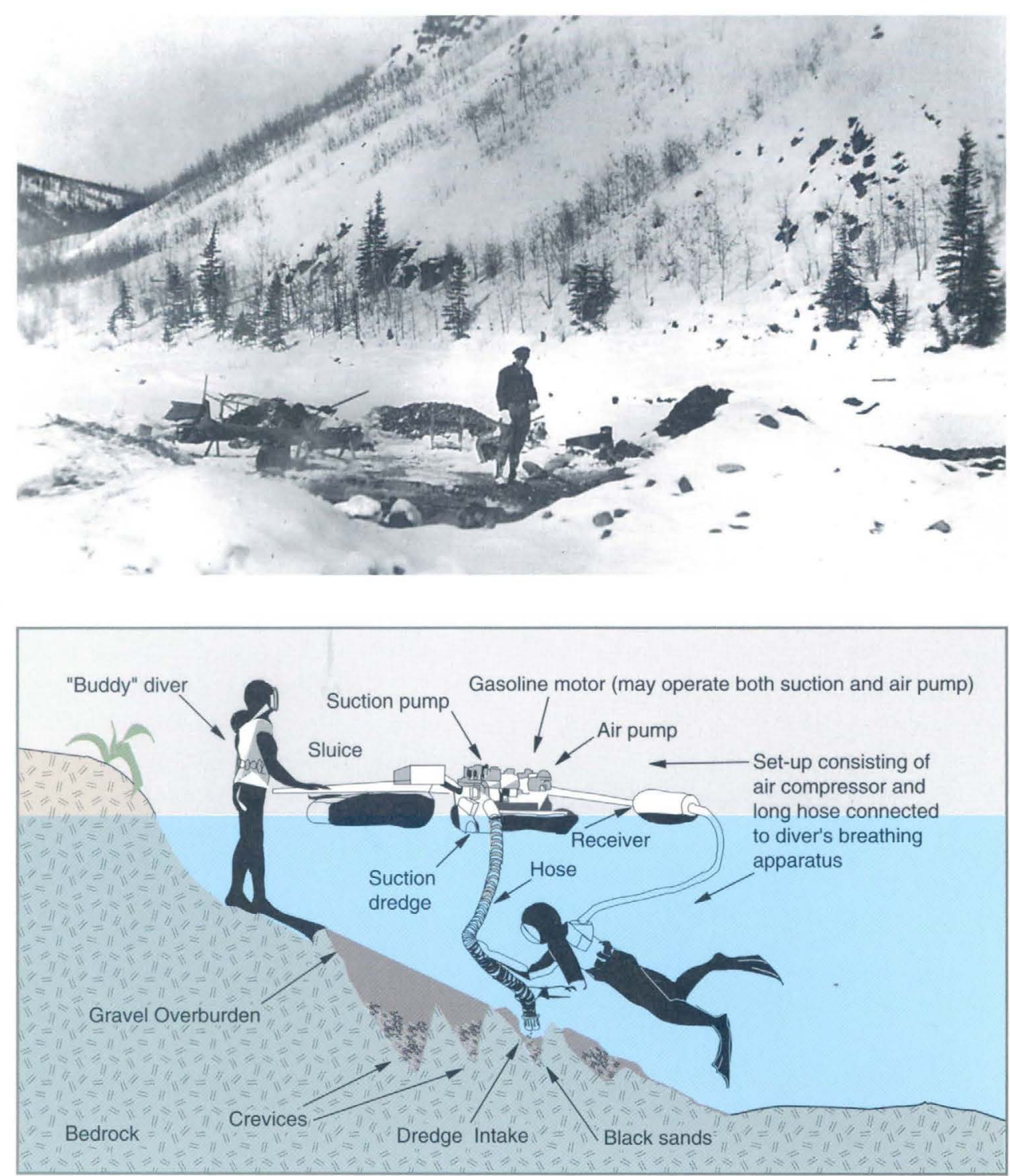

The gold price rise in the late 1970's caused a renewed rush to placer mines throughout Alaska. Numerous floating suction dredge operations have appeared on the Fortymile River during the 1980's and 1990's. As many as 20 separate dredges were operating in the summer of 1992 scattered along the river all the way to the Canadian border. The operations employ snorkel or scuba techniques using compressors, air tanks, and suction hoses as much as 12 inches (30 centimeters) in diameter (fig. 14). The suction dredge miners typically describe a poor day as one during which $1 / 2$ ounce or less of gold is recovered, whereas a good day is one during which 2 to 3 ounces of gold is recovered. These miners operate on so-called "river claims" that run parallel to the river with lateral boundaries at mean high-water level. Although they seldom produce enough gold to sustain a commercial operation, the bars along the Fortymile do provide an excellent opportunity for recreational mining.

The gneiss, schist, amphibolite, and marble unit forms the major part of bedrock exposed in the drainage basin of the Fortymile River. Marble beds are easily recognized in the river valley where they have been polished and scoured by the river. A walking traverse along the river's edge several miles below the Taylor Highway bridge reveals that the gravels are largely restricted to bars scattered along the river; the boulders and cobbles, most of which are about 4 to 8 inches (10 to 20 centimeters) in diameter, are well rounded
Figure 13 WINTER MINING IN BED OF FORTYMILE RIVER, 1921 at "Swansons Diggings" in east-central Alaska. The ice was picked away and the frozen gravel was thawed to bedrock using open wood fires. Photo courtesy of University of Alaska Archives, Fairbanks, Alaska.

Figure 14 TYPICAL GOLD-DIVING OPERATION USING A SUCTION DREDGE (Modified from Clark, 1978). 
to subrounded. Cobbles and boulders sometimes form a pavement on the valley floor adjacent to the river. The clast composition of the gravels in the river floodplain reflects both the adjacent bedrock types and the presence or absence of adjacent high terrace gravel deposits. Commonly two markedly different suites of boulders and cobbles are presentwell-rounded, light-colored quartz, quartzite, granite, and other plutonic rocks clearly derived from the high terrace gravels, and subangular to subrounded clasts of schist, gniess, and greenstone eroded from the adjacent river canyon walls. As much as 30 percent of the clasts are derived from the high terrace gravels, as the following pebble count, obtained near the Taylor Highway bridge, indicates: (1) well-rounded clasts -9 percent quartz, 3 percent quartzite, and 18 percent granite and other light-colored plutonic rocks; (2) subangular to subrounded clasts - 50 percent greenstone, 14 percent schist, 1 percent marble, and 5 percent quartzite (No. 8, pl. 1). The steeply dipping foliation obliquely transverse to the water flow and the not uncommon occurrence of potholes (fig. 15) produce excellent gold traps. The gravel thickness in the river bed, as reported by several suction dredge miners, is generally 1 meter or less; however, some "holes" may contain as much as 33 feet (10 meters) of gravel. Gold is fine and flaky, and it can almost always be recovered by panning when sampling gravel at the gravel-bedrock contact in the floodplain of the Fortymile River. The early miners termed the Fortymile a "bedrock" creek because its bed contained little or no detrital material. In many places, these early miners used knives to scrape the bedrock to gather the small amount of detritus and its accompanying gold (Ogilvie, 1897).

Remnants of the high terrace gravels are common along much of the Fortymile River and probably have provided a sizable percentage of gold that has been mined. The high

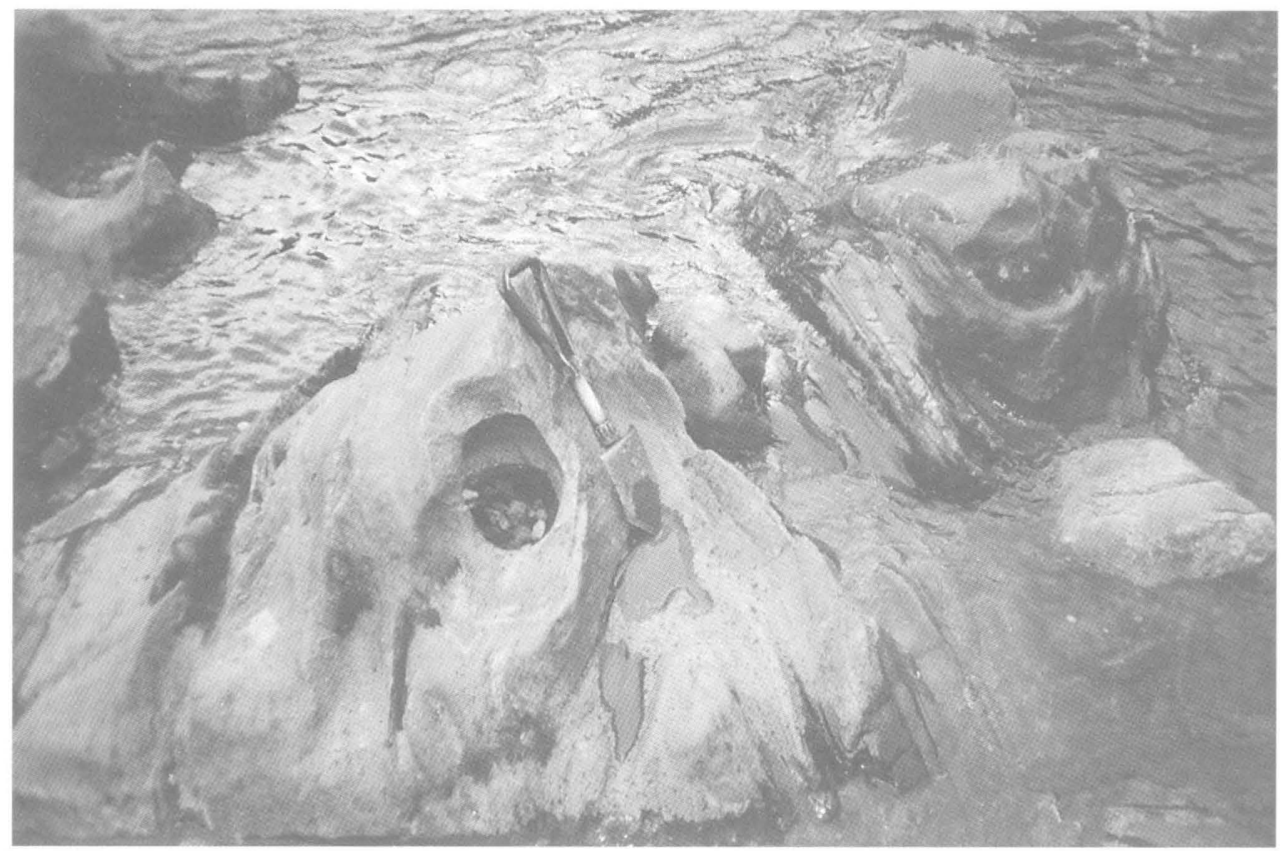
terrace gravels are as much as 600 feet (180 meters) above the present river in the more downvalley areas, but upstream, this difference decreases (fig. 16). Mertie (1938) observed this relation and concluded that the ancestral Fortymile River had a lower gradient than the present river. The ancestral Fortymile River and its major tributaries, the North and South Forks, must have had a broad floodplain, roughly 1 to 2 miles (2 to 3 kilometers) wide, and a gradient of about 4 feet per mile ( 0.76 meters per kilometer), as

Figure 15 POTHOLE developed in gneiss along lower Fortymile River in east-central Alaska. Such erosional features are superb traps for gold and are mined either by hand excavation when present above water level or by suction dredge when present below water level. indicated by the outcrop remnants of the high terrace gravels (pl. 1). It is reasonable to conclude, therefore, that compared to the present Fortymile River, the ancestral Fortymile was in a much more mature phase of development and would, typically, have had a lower gradient. Base-level lowering allowed the Fortymile River to cut into its floodplain and develop the youthful characteristics it has today, such as its V-shaped canyon, narrow floodplain (fig. 17), and a gradient of at least twice that of the old river ( 9 feet per mile; 1.7 meters per kilometer).

The Fortymile River was being designated by Congress as a National Wild and Scenic River in 1980; however, the rights of existing mining districts are protected and pro- 

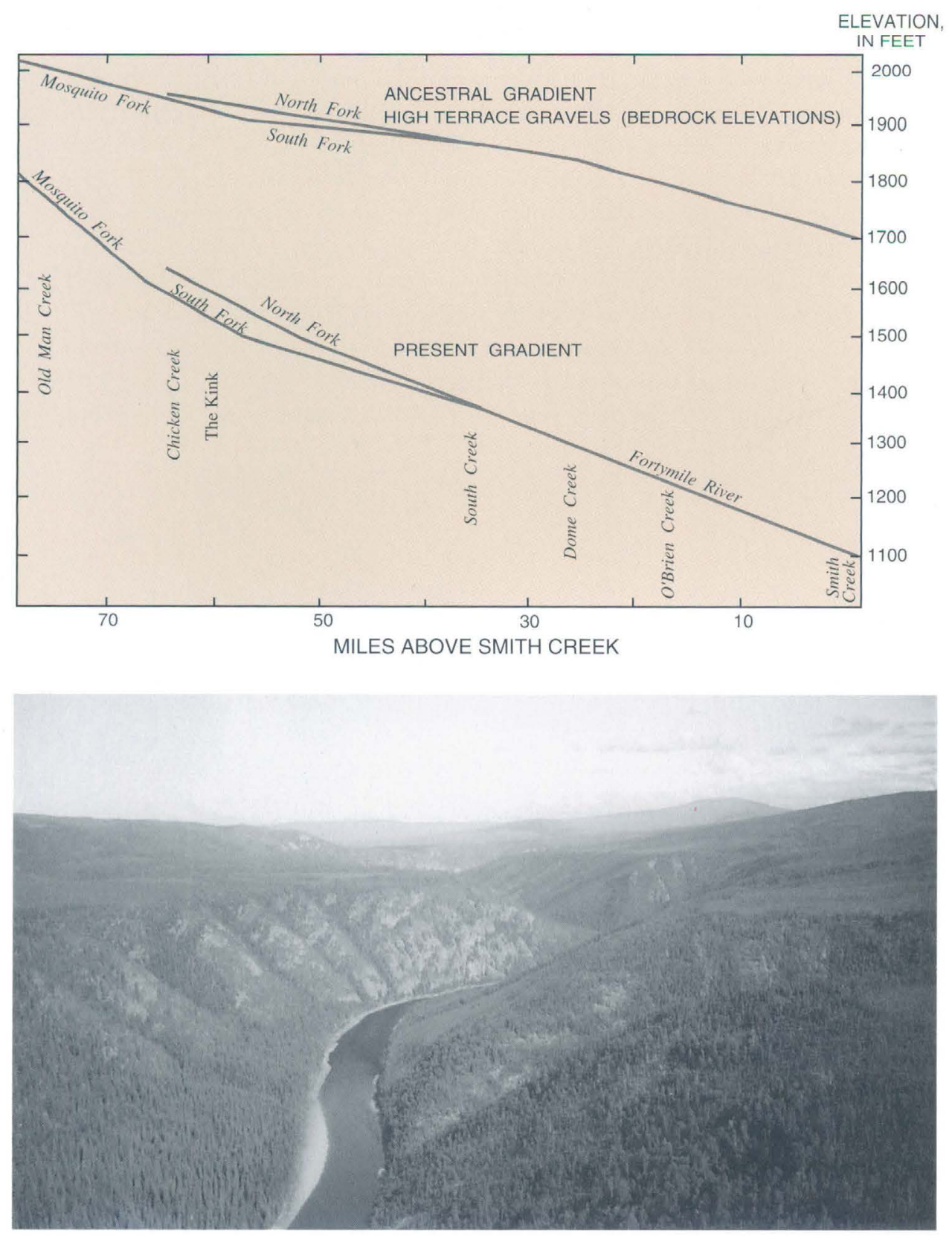

vided for in the designation of the wild and scenic rivers. The Federal Government owns the 1/2-mile-wide (.8-kilometer) corridor along the River; however, as a result of the 1953 Submerged Land Act, the State of Alaska owns all of its navigable rivers, of which the Fortymile is one. Miners, therefore, need state permits to operate suction dredges in the river and the Federal Government's (BLM) permission to set up camps on adjacent Federal land. The Environmental Protection Agency and the Alaska Department of Environmental Conservation have placed stringent regulations on all commercial mining operations on the Fortymile River particularly pertaining to the turbidity of waste-water discharge. These regulations have discouraged all but a few suction dredgers-the large operators have concentrated their efforts on mining other creeks in the district not designated as wild and scenic.

The Fortymile River, instead of being the big producer in the district, provided the discovery enticement and easy route that led the miners to the more productive tributary creeks.
Figure 16 PROFILES SHOWING PRESENT RIVER GRADIENTS (average of 9 feet per mile or 1.7 meters per kilometer) compared to gentler gradients of the older, ancestral rivers (average of 4 feet per mile or .76 meter per kilometer), as determined from remnants of the high terrace gravels. Profiles extend from near the Canadian border (Smith Creek) to the west and south up the North Fork of the Fortymile River and the Mosquito Fork.

Figure 17 AERIAL VIEW LOOKING EAST DOWN FORTYMILE RIVER east-central Alaska, showing the narrow, V-shaped canyon, narrow floodplain, and well-developed high terraces cut on bedrock. The terraces are mantled with thin (3.3 to 6.5 feet or 1 to 2 meters) veneer of gold-bearing gravel, and they are about 500 feet $(150 \mathrm{~m})$ above the Fortymile River. 


\section{WALKer Fork}

This discussion of the Walker Fork drainage includes the principal tributaries-Poker, Davis, Younger, Cherry, and Twelvemile Creeks. Davis, Poker, and Younger Creeks head in Canada flowing in narrow valleys for 0.6 to 1.2 miles ( 1 to 2 kilometers) before entering Alaska (fig. 18). Most, if not all, of the gold mined from these creeks has been in Alaska.

Gold was first discovered in this area in 1888 by Jim Davis about 0.6 miles ( 1 kilometer) above the mouth of the creek subsequently named for him, and a small "rush" ensued (Naske, 1977). The following year gold was found on Poker Creek, and most of the headwater region of Walker Fork was quickly staked. Although these creeks with narrow valleys and small drainage basins rarely supplied sufficient water for mining, they were mostly mined out by the turn of the century and the miners moved down to the upper part of the main river-Walker Fork. Hydraulic opencut methods were initially used to mine the plac-

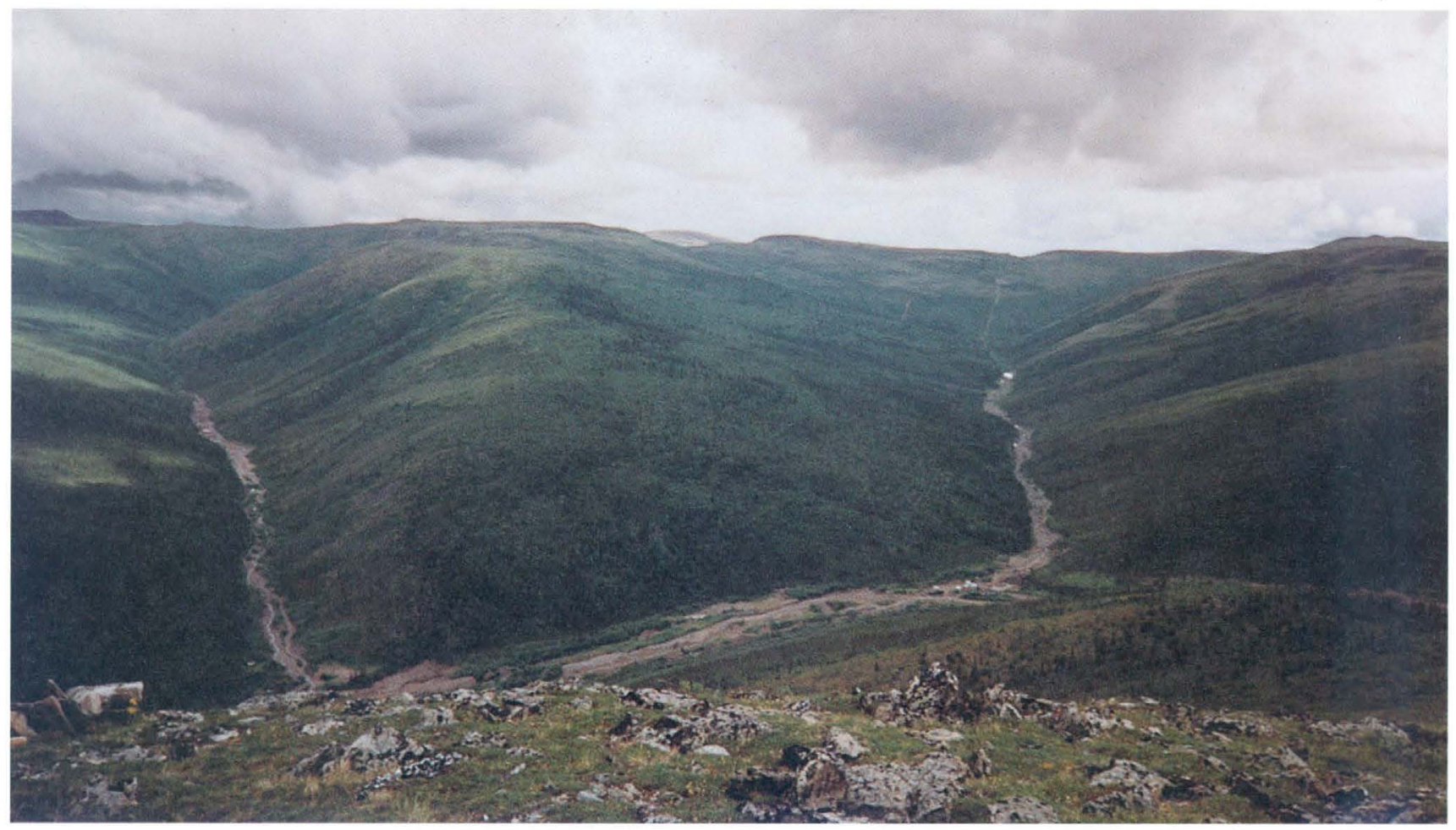

Figure 18 VIEW NORTHEAST INTO YUKON TERRITORY CANADA, UP DAVIS AND POKER CREEK VALLEYS. Mined gravel tailings are light gray areas in valley bottoms, and upvalley at the Canadian border. Mined gravel in streambed of Walker Fork is evident in middle distance. ers, but by 1903, steam and horse-drawn scrapers and bucket conveyors were in use. Annual gold production from Walker Fork and its headwater tributaries during the first few years of the 1900's was about 1,000 to 1,500 ounces from the efforts of 40 men (Prindle, 1905).

In 1907, the first bucket-type dredge began to work on Walker Fork, about 1 mile (1.6 kilometers) above the mouth of Twelvemile Creek. It was a small dredge with a bucket capacity of 0.18 cubic yards (0.14 cubic meters). It operated on Walker Fork from 1907 to 1909 and was then moved to the South Fork of the Fortymile near the mouth of Uhler Creek (Mertie, 1938). A second dredge was installed on Walker Fork between the mouth of Davis and Poker Creeks in the winter of 1907-08 by Robert Mulvane. Eventually referred to as the "Mulvane Dredge," it successfully operated from 1908 to 1912 and its operations ended on Poker Creek several hundred meters above the mouth of the creek. It was then dismantled and moved to Miller Creek in the Sixtymile District of Canada (Mertie, 1938).

The Walker Fork Gold Corporation owned and mined some 14 miles (22 kilometers) of claims on Walker Fork in the 1920's (Naske, 1977). The corporation combined hydraulic 
and steam-shovel methods with elevated sluice boxes. Hydraulic giants were used to move gravel to areas where it was picked up by a steam shovel and hoisted into the elevated sluice boxes (Mertie, 1930). This type of operation was continued until 1934 when a stackertype dredge was introduced to the area (Mertie, 1938). This dredge had buckets with a capacity of 0.11 cubic yards ( 0.084 cubic meters) and consumed 5 to 6 cords of wood each day. Mertie (1938) described this dredge in detail. Because the ground was frozen, it was necessary to strip the overlying muck ahead of the dredge and thus allow the gold-rich gravel to thaw naturally from the Sun's heat. Steam points were not used for melting as was the case elsewhere in Alaska, rather hydraulic giants were used to strip away the frozen overlying muck. This dredge operated until 1938 when it was shut down because of financial difficulties, and the holdings were taken over by the Northern Commercial Company (Naske, 1977). The inoperable remains of this dredge can be seen today at the end of the dredge-tailing field in Walker Fork just above the mouth of Cherry Creek.

Mining has been sporadic in this area from 1948 to the present. Bulldozers and backhoes moving gravel to sluice boxes is a common mining method. In 1955 the LaCross Mining Company produced 965 ounces of gold and 137 ounces of silver from 20,000 cubic yards (15,000 cubic meters) of gravel (Naske, 1977). Small opencut operations in the early 1990's have been observed on Davis and Younger Creeks, a small tributary of Cherry Creek, and at least two locations on the main channel of Walker Fork (pl. 1). The lower .9 mile (1.5 kilometers) of Twelvelmile Creek appears to have been mined, as indicated by the presence of tailing piles; however, it is not known exactly when this mining took place (fig. 19). Some small-scale mining may have also occurred on Turk Creek, a tributary of Cherry Creek. Small suction dredges are occasionally seen on Walker Fork during the summer months near the Taylor Highway bridge.

Walker Fork and its tributaries drain an area primarily underlain by the gneiss, schist, amphibolite, and marble unit, which is the bedrock in the area (pl. 1). However, Poker Davis, and Younger Creeks drain areas underlain by greenschist facies rock that is distinctly lower metamorphic grade than rock underlying Walker Fork. Quartz veins of various widths generally are parallel to cleavage in the rocks. A flake of free gold (.03-.07 inches or 1-2 millimeters) was reportedly observed in one of the quartz veins on Davis Creek (Spurr, 1898).

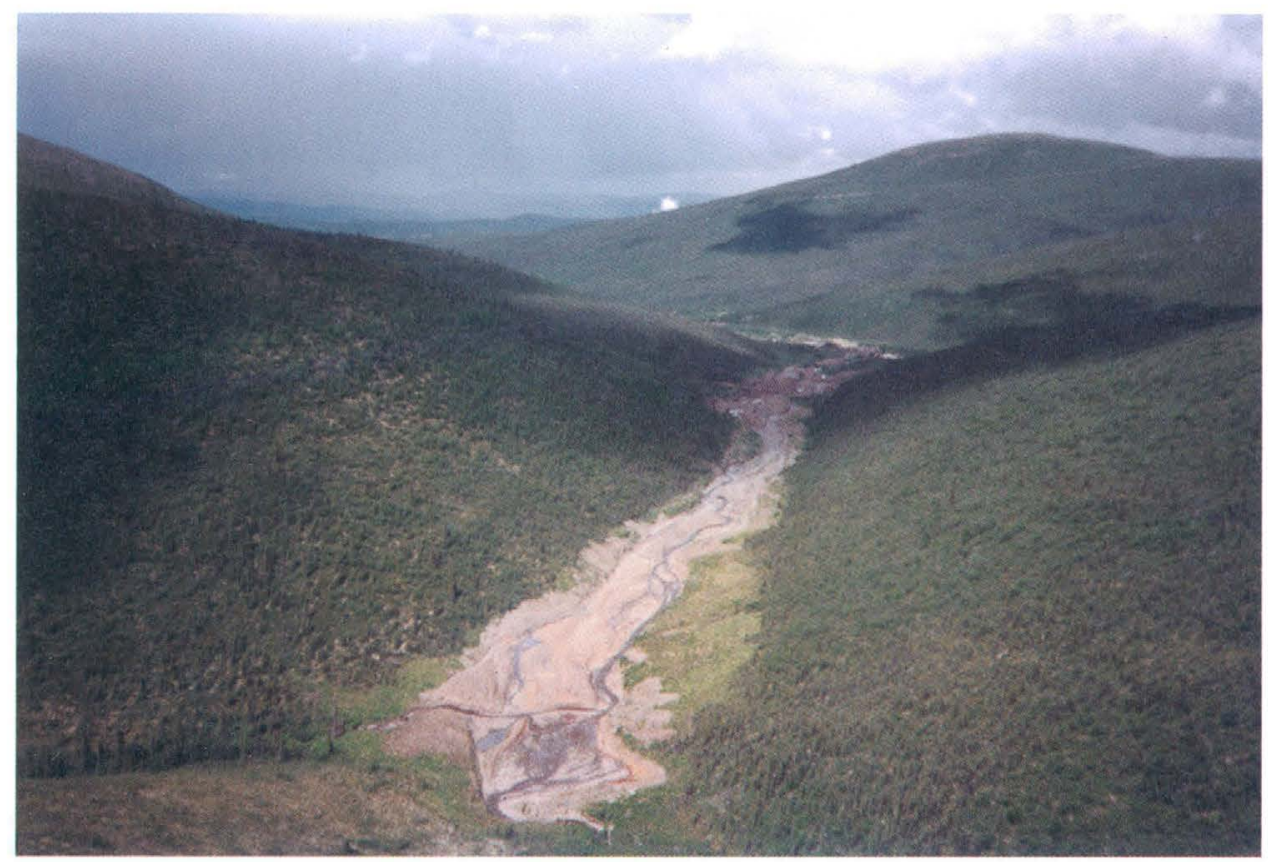

Figure 19 AERIAL VIEW DOWN LOWER 0.9 MILE (1.5 KILOMETERS) OF TWELVEMILE CREEK in east-central Alaska showing mined gravel. 
Pebble counts from eight different locations (table 2) within Walker Fork and its principal tributaries show that the gravel is composed predominantly of subangular to subrounded clasts of schist, quartzite, and quartz. Clasts are as much as 1 meter in diameter, however, most clasts are slab-shaped cobbles and boulders 1.5 to 4 inches (4 to 10 centimeters) in diameter. The gravel in the upper, mined-out part of Walker Fork ranged from 3 to 10 feet ( 1 to 3 meters) in thickness. In places a thin layer of clay was found between the gravel and bedrock. The pay streak ranged from 50 to 590 feet (15 to 180 meters) in width, and the bulk of the gold was present in the lower 3 feet (1/meter) of gravel and upper 1.5 feet ( 0.5 meter) of bedrock. Most of the gold recovered was small and flat, but nuggets as much as 1 ounce were recovered. Some gold was rusty and black in color. Values ranged from $\$ 5$ to $\$ 35$ per cubic yard ( $\$ 3.80$ to $\$ 29$ per cubic meter) (Mertie, 1938; Prindle, 1905). Current mining of some of the dredge tailings in Walker Fork reportedly yields $\$ 3.75$ to 5.00 per cubic yard ( $\$ 2.85-3.82$ per cubic meter).

Table 2. Pebble counts expressed in percentages for selected localities in Walker Fork drainage, Fortymile Mining District, east-central Alaska

[Location numbers (in parentheses) are keyed to plate $1 ;-$, not present]

\begin{tabular}{|c|c|c|c|c|c|c|c|c|c|}
\hline \multirow[t]{2}{*}{ Locations } & \multicolumn{9}{|c|}{ Rock types } \\
\hline & Schist & Quartzite & Quartz & $\begin{array}{l}\text { Green- } \\
\text { schist }\end{array}$ & Granitic & $\begin{array}{c}\text { Pegma- } \\
\text { tite }\end{array}$ & Gneiss & Marble & $\begin{array}{l}\text { Ultramafic } \\
\text { rock }\end{array}$ \\
\hline Poker Creek (9) & 66 & 22 & 12 & - & - & - & - & - & - \\
\hline Davis Creek (10) & 85 & - & 15 & - & - & - & - & - & 一 \\
\hline Cherry Creek (11) & 32 & 4 & 14 & 20 & 14 & 16 & - & - & - \\
\hline Lower Walker Fork (12) & 30 & 34 & 10 & - & 8 & - & 10 & 10 & - \\
\hline Walker Fork near dredge (13) & 28 & 30 & 18 & 8 & 10 & 2 & 4 & - & - \\
\hline Upper Walker Fork (14) & 48 & 40 & 10 & 2 & - & - & - & - & - \\
\hline Twelvemile Creek (\$5) & 40 & 10 & 8 & - & 26 & - & 16 & - & - \\
\hline Turk Creek (16) & 12 & 12 & 2 & 28 & 8 & 6 & - & 16 & 16 \\
\hline
\end{tabular}

Much of the gravel in the Walker Fork valley below Cherry Creek is unmined (pl. 1). Gravel here is judged to be too low in value to be an economic resource at current market conditions, and it is probably for this reason that the dredge ceased mining just above the mouth of Cherry Creek. The floodplain is 1,640 to 2,625 feet (500 to 800 meters) wide, and the large amount of gravel present results in dilution of the placer gold.

A low terrace roughly 100 to 130 feet ( 30 to 40 meters) above the valley bottom is present along much of the north side of Walker Fork and east side of Cherry Creek (pl. 1). The terrace has been covered by 3 to 10 feet ( 1 to 3 meters) of muck by solifluction and slumping activity such that the original flat surface now slopes toward the valley bottom. Still, with some vigorous hand digging, 3 to 6.5 feet ( 1 to 2 meters) of gravel on bedrock can be exposed at the downslope edge of the terrace and gold can be panned from the gravel1 or 2 millimeter-sized flakes per pan. A moderate gold resource may be present along this middle section of Walker Fork, within both the floodplain and terrace gravels, but it will probably have to await more favorable market conditions (higher gold price, lower mining costs) before being mined.

\section{SOUTH ForK}

South Fork is, predictably, the south fork of the Fortymile River. Approximately 27 miles (43 kilometers) long, it flows east from the junction of the Mosquito and Dennison Fork of the South Fork of the Fortymile River to Atwater Creek where it meanders north and eventually joins the main Fortymile River. 
Gold was discovered on the South Fork at a place referred to by the early miners as "Troublesome Point," which is about $1 / 4$ mile ( 0.4 kilometer) below the mouth of Franklin Creek. This locality is not a recognized geographic name and does not appear on the map. A Slavonian called Crooked Leg Louie and his partner were mining gold here in 1887 . The area was called Troublesome point because of the trouble the claims' wealth caused these two. Howard Franklin subsequently found gold on Franklin Gulch (now called Franklin Creek) largely because he believed the gold at Troublesome Point was coming from the first creek above it (Buteau, 1967). In 1889 the Troublesome Point claims were purchased by George Madlock, Pete McDonald, John Campbell, and Frank Buteau. Using a rocker, they reportedly made $\$ 75$ per day per man that summer. During the winter of 1889-90, these partners whipsawed enough lumber to build a flume for carrying water from Franklin Creek to their workings on the South Fork at Troublesome Point. According to Buteau (1967), they used this water to mine hydraulically and in so doing were the first to use this method in the Yukon River valley. The partners took $\$ 10,000$ worth of gold from their claims at Troublesome Point. Various versions of the details of this mining effort are reported by Buteau (1967) and Haynes (1976).

It was the bucketline dredge, however, that was most frequently used for mining placer gold in the early history of the South Fork. The early history of dredging here is sketchy.

The first dredge used was called the Little Dipper dredge. It was built in 1907 at a location referred to as "pump bar," 2.5 miles (4 kilometer) downstream from the mouth of Franklin Creek. This dredge had a bucket capacity of 2.5 cubic yards ( 1.9 cubic meters) and was capable of digging about 100 cubic yards ( 76 cubic meters) per hour. The gravel here was unfrozen and averaged about 6 feet (1.8 meters) in thickness (Prindle, 1908). The dredge was wrecked by spring runoff in 1908 (Mertie, 1938).

A dredge called the Russell King, was moved by horses from Walker Fork during the winter of 1910 to the vicinity of "pump bar." It operated upriver from this locality for about four years. While working below the mouth of Franklin Creek, it was making a good profit, but once it passed the mouth of Franklin Creek the values fell off markedly. Therefore, it was concluded that much of the gold in the South Fork at this locality was coming out of Franklin Creek. It became unprofitable to mine and the dredge was shut down about 1914. In the winter of 1935-1936, the dredge was purchased by the North American Mining Company and moved with horses and sleds to Wade Creek (Mertie, 1938).

Another dredge, the Atwater dredge, is known to have been operating on the South Fork near the mouth of Buckskin Creek in 1912 and 1913 (Mertie, 1938) (fig. 20 and cover).

The Lost Chicken dredge was shipped from Skagway to Whitehorse on the White Pass and Yukon

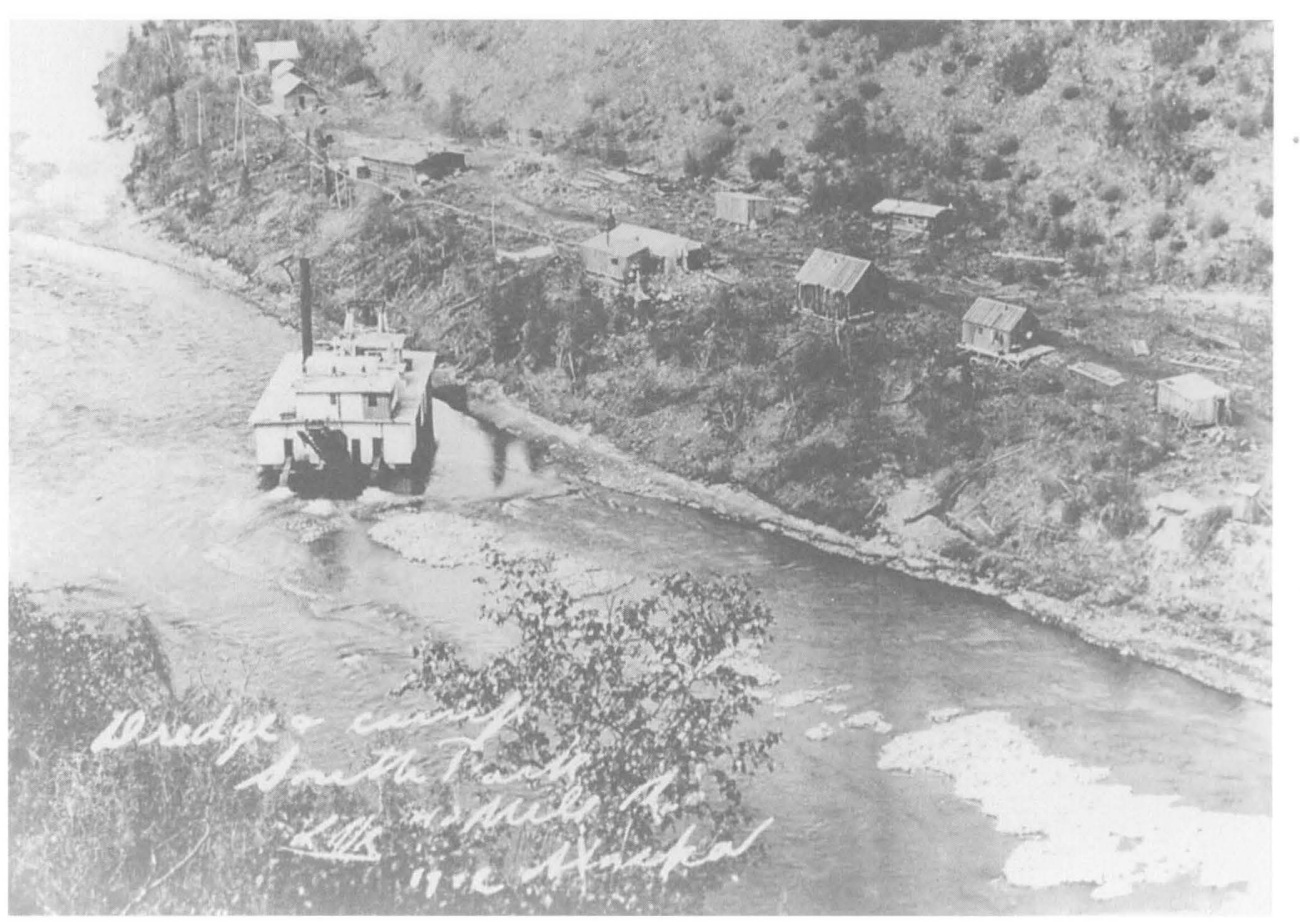


Figure 21 REMAINS OF LOST CHICKEN DREDGE on Mosquito Fork about 1.2 miles (2 kilometers) above mouth of Lost Chicken Creek, east-central, Alaska.
Railroad, from Whitehorse to the mouth of the Fortymile River by steamboat, and, during the winter of 1936 by caterpillar tractors up the Fortymile River and South Fork to a point about .9 mile (1.5 kilometers) below the mouth of Lost Chicken Creek. It was believed that a large bar below the mouth of Lost Chicken Creek might contain considerable gold that had come from the Lost Chicken Creek valley. Owned and operated by the Alaska Gold Dredging Corporation, the dredge burned coal obtained from the area around Chicken, but soon switched to wood because the coal was of such poor quality that it could not provide sufficient heat to run the dredge. The dredge had 64 buckets, each with a capacity of only 0.14 cubic yards ( 0.11 cubic meters), and burned about 7 cords of wood per day. Thirteen men were required to operate the dredge, and they worked in three shifts of 8 hours each. In the 1936 season, the dredge worked upriver mining gravel 1.4 to 6.5 feet $(0.5$ to 2 meters) in thickness, taking a cut 150 feet (46 meters) wide and extending 1,200 feet (366 meters) along the river. The gold recovered was very fine grained and had a fineness of 900 (Mertie, 1938). A detailed description of this dredge is included in Mertie (1938). The dredge worked for about $11 / 2$ years until the Northern Commercial Company took over and shut it down. It is believed that this dredge, in great disrepair, is the one now present 1.2 miles (2 kilometers) below BLM Chicken Station on the Mosquito Fork River (fig. 21).

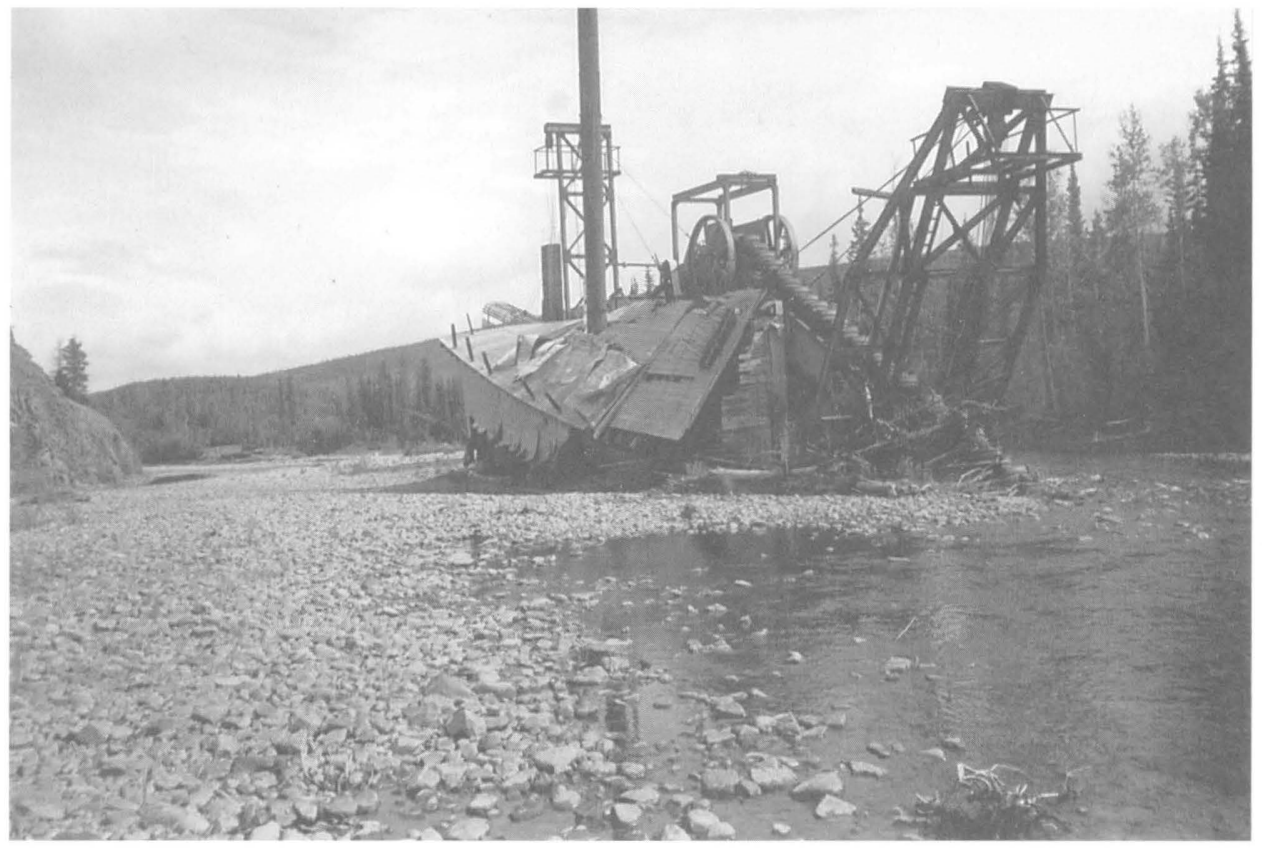

Today, placer mining along the South Fork is almost exclusively done by suction dredging. As many as 12 separate operations were observed working along the river during the summer of 1991. The most actively mined area seems to be the stretch of river between Dennison Fork and Atwater Creek (fig. 22)

The bedrock in the valley of the South Fork is primarily quartzite and schist of the gneiss, schist, amphibolite, and marble unit (fig. 5) with a short stretch of the upper river in granitic rocks and a small area near the mouth of Napoleon Creek underlain by Tertiary sedimentary deposits. Pebble counts from three locations along the river show a preponderance of schist, quartzite, and granitic clasts (table 3). Much of the alluvium along the South Fork is incorporated in the colluvium unit (pl. 1). Gravel is present as bars along the river and it consists of subangular to subrounded, generally slab shaped clasts. Boulders as much as 3 feet ( 1 meter) are rare; more commonly, clasts are 2 to 8 inches ( 5 to 20 centimeters) in diameter. Thickness of the gravel on the river floor, as reported by the suction dredge miners, is 2.5 inches to 10 feet (6 centimeters to 3 meters). Information on gold 


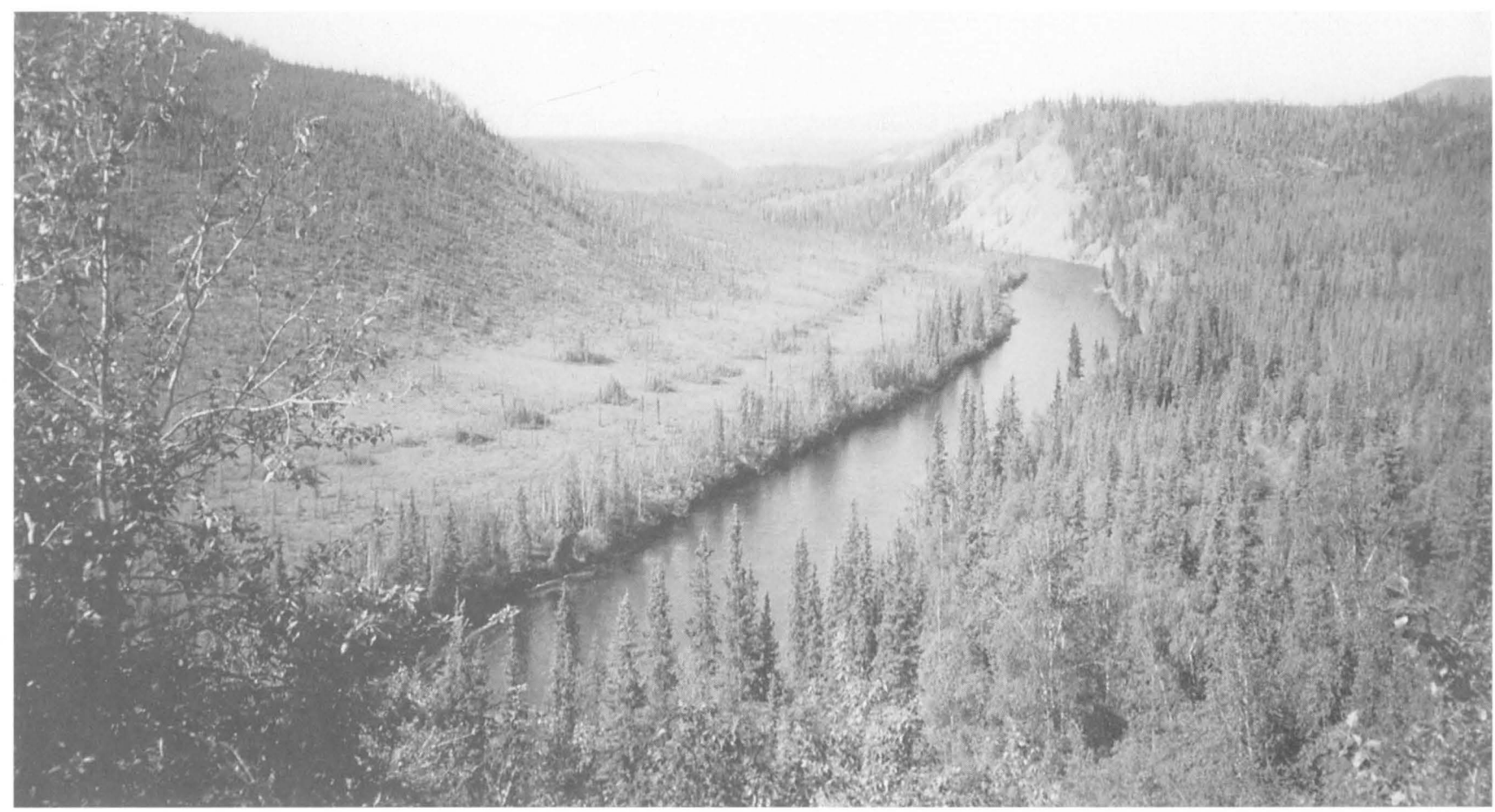

values is not available because records from the old bucket dredges don't exist. A 30 ounce nugget was recovered near the mouth of Franklin Creek (Mertie, 1938). High terrace gravels are present along the lower 18 miles (28 kilometers) of the South Fork valley, although none has been mined.

Based on the locations where most of the gold has been found in the South Fork River valley both by the older bucket dredges, and by contemporary suction dredges, it seems clear that the tributary drainages of Lost Chicken, Napoleon, Franklin, and Buckskin Creeks have supplied the bulk of the gold to the South Fork valley. Gold is present in the high terraces, but the location of areas that would be economic to mine today await discovery. They, of course, present problems to mining because of the expense of bringing water to the gravel or the gravel to the water. The South Fork will continue to be a popular river for suction dredging because yearly ephemeral shifts in the channel flow uncover, move, and reconcentrate gold that is still present.

\begin{tabular}{|c|c|c|c|c|c|c|}
\hline \multirow[t]{2}{*}{ Locations } & \multicolumn{6}{|c|}{ Rock types } \\
\hline & Granite & Quartzite & Schist & Quartz & Gneiss & Other \\
\hline $1.5 \mathrm{~km}$ east of mouth of Chicken Creek (17) & 44 & 30 & 22 & 4 & - & - \\
\hline $1.5 \mathrm{~km}$ south of mouth of Franklin Creek (18) & 46 & 26 & 20 & 2 & - & 6 \\
\hline Taylor Highway bridge over South Fork (19) & 30 & 20 & 28 & - & 14 & 6 \\
\hline
\end{tabular}

\section{WADE Creek}

Wade Creek, sometimes referred to as Jack Wade Creek, flows in a nearly straight, narrow valley for 12 miles (19 kilometers) before emptying into Walker Fork River near the Walker Fork campground. Gold was discovered on the creek about 1895 by Jack Anderson and Wade Nelson, the original locators and those for whom the creek was subsequently
Figure 22 LOOKING WEST UP SOUTH FORK VALLEY JUST WEST OF ATWATER CREEK, in east-central Alaska. This area is about 2 miles (3 kilometers) down river from the mouth of Lost Chicken Creek from which it may have received abundant placer gold. This area is a popular spot for suction dredging. 
Figure 23 THE DREDGE IN WADE CREEK (east-central Alaska), sometimes referred to as the Jack Wade dredge. This dredge operated in Wade Creek from 1936 to 1941. named; and gold has been mined almost continuously since. A U.S. Commissioner was stationed at the community of Jack Wade on Wade Creek in the early years. He could record mining claims, and thus make it convenient for local prospectors who would otherwise have had to go to Eagle to record their claims. Two discovery claims are recognized on Wade Creek, and claims were staked from each, both up and down the creek.

In the early (pre-1910) history of the creek, mining was by drifting, hydraulicking, and opencuts. The ground was thawed using steam, hot rocks, and wood fires. Drifting was done mostly in the winter and the gravel was washed in the spring (Prindle, 1905). Because of the partly thawed character of the ground, extensive underground work was not feasible. Large-scale opencut mining has been used largely in the upper part of the Wade Creek valley. Prindle (1905) reported that by 1904 much of the ground in the creek had been worked out, water was frequently in short supply in the narrow valley, and about 50 men were mining on the creek. Hydraulic methods using canvas hose were used to strip the overlying muck from the gravel, and the gold-bearing gravel was shoveled into sluice boxes. Production from 1904 through 1907 totaled about 16,230 ounces (Eberlein and others, 1977). Mertie (1930) described in detail the hydraulic plant in operation on the creek in 1928. During the 1936 season, one hydraulic plant and several small shoveling-in operations were present on the creek. Mining was done in parallel cuts about 30 feet ( 9 meters) wide (Mertie, 1938).

The Russell King dredge was one of the smallest used in the Fortymile area-it had buckets of only 0.17 cubic-yard ( 0.13 cubic meters) capacity. The dredge was moved from the South Fork to Wade Creek and began operating there in 1936. It operated until 1938 when ownership changed to the Yukon Placer Company. Although this dredge required only three men to operate it (winchman, oiler, and fireman), 30 men were kept busy cut-

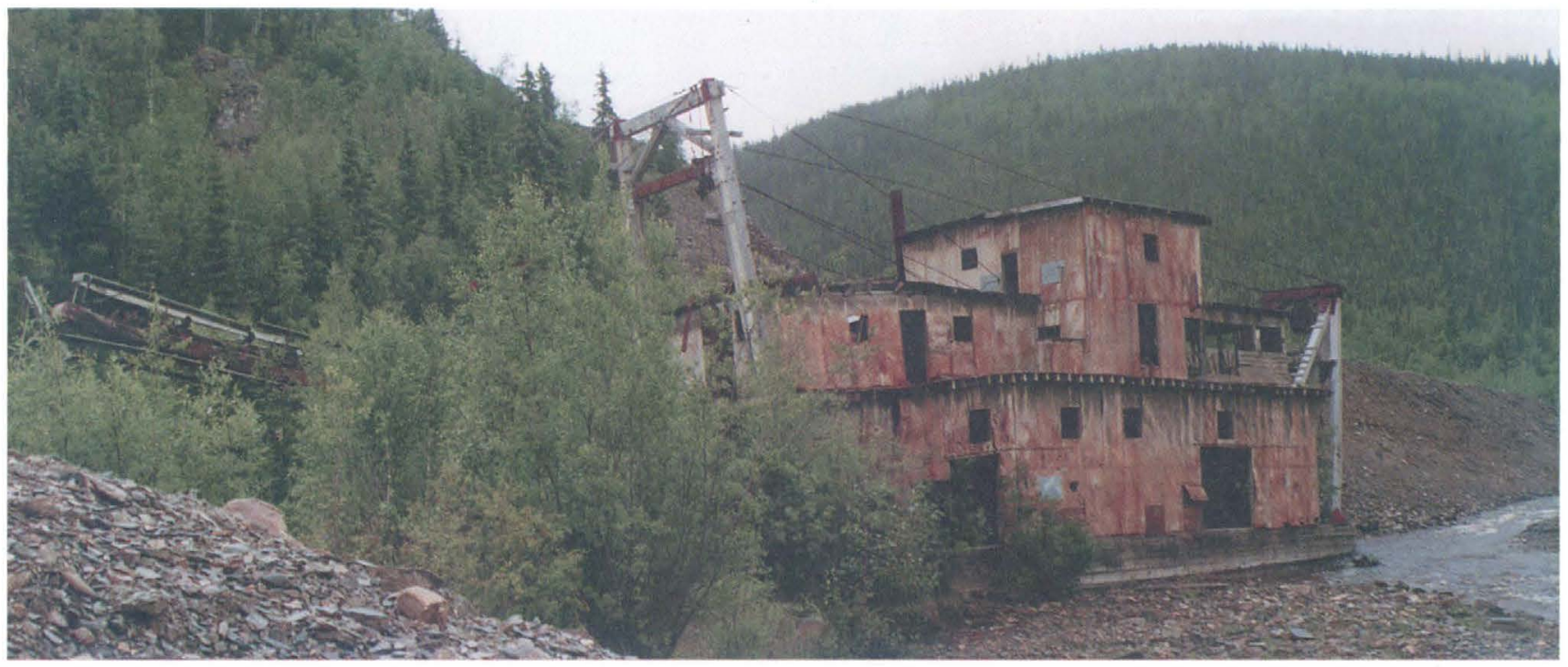

ting wood for the boiler. The operating season usually lasted from June through October. The dredge would operate for 12 hours per day, and at the end of 10 days would shut down and the sluice boxes would be cleaned up. Gold was recovered at the rate of about 70 to 100 ounces per day (Naske, 1977). The dredge was shut down in 1941 for mechanical reasons. In 1942, the U.S. Government forced the Yukon Placer Company to lease their tractors and heavy equipment to the Government for the war effort, which resulted in the shut-down of gold mining on Wade Creek. The dredge was subsequently cannibalized for parts and has not operated since. The Bureau of Land Management placed an interpretive sign on the dredge, and it is viewed by thousands of tourists each summer passing through the Fortymile area along the Taylor Highway (fig. 23). 
Following the war, the Wade Creek Dredging Company continued to mine on Wade Creek using bulldozers and sluice boxes. Between 1946 and 1947, the company recovered slightly more than 5,000 ounces of gold (Naske, 1977). The Wade Creek Dredging Company ceased mining operations here at the end of the 1951 season and planned to move to Canada. Small, almost continuous mining operations using bulldozers have existed on Wade Creek during the past 40 years. From 1990-93, an occasional small suction dredge operated in the creek.

Wade Creek flows entirely within quartzite and schist of the gneiss, schist, amphibolite, and marble unit. Minor amounts of granitic rocks are exposed in the headwaters of some of its tributaries. Pebble counts within the creek floodplain (one near the head and one near the mouth, pl. 1, No. 20) reveal the following composition: 43 percent schist, 30 percent quartzite, 13 percent quartz, 9 percent granite, and 5 percent gneiss. Quartz veins, some of which are pyritiferous, are present in the schist and some contain gold. A vein present in the upper part of the creek was assayed at 0.06 ounce of gold per ton (Prindle, 1905). Gold with attached quartz is commonly found in the placers.

The gravel within Wade Creek contains subangular to subrounded boul-

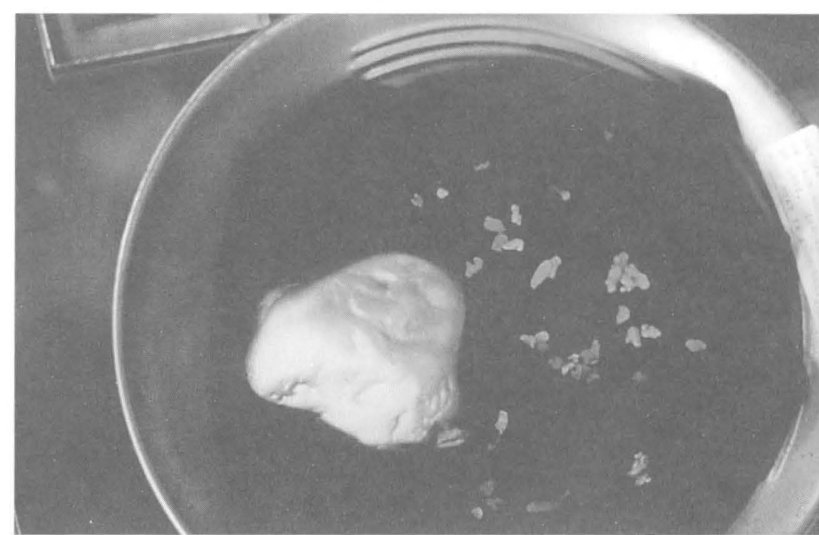
ders as much as 3.3 feet ( 1 meter) across, but they are more commonly 2 to 8 inches ( 5 to 20 centimeters) across. Prior to mining, the gravel was described as being a little over 3 to 13 feet (1 to 4 meters) thick on the valley floor (Mertie, 1938). A few low benches covered with thin gravel veneer have mostly been mined. Most of the gold has been found in the lower 1.5 feet ( 0.5 meter) of gravel and upper 3.3 feet ( 1 meter) of broken schist and quartzitic bedrock (Mertie, 1938; Prindle, 1905).

Wade Creek is known for the occurrence of large gold nuggets. Nuggets of 25, 33, 56, and 70 ounces are examples of the larger ones recovered (fig. 24). Most of the gold recovered from the creek is coarse and some is iron-stained. Values of $\$ 10$ to $\$ 50$ per cubic yard (\$7.65 to \$38.25 per cubic meter) for gravels in the creek have been reported (Prindle, 1905). Rounded barite pebbles, black shiny rounded grains of hematite, and scheelite grains are sometimes found associated with the gold in the heavy fraction. Fineness values of gold recovered between 1926 and 1935 by one miner on the upper part of the creek ranged from 807 to 842 , with a mean of 830 (Mertie, 1938).

The geologic map (pl. 1) shows the gravel in Wade Creek as being completely mined. There are still small pockets of unmined gravel on the valley margins too small to show at the scale of the map. Mine tailings are often rewashed and almost always yield some gold. Because the gravel-bedrock contact was not always thoroughly cleaned in the early mining efforts, this area could still have gold values. Occasionally, a large nugget is found on the gravel just beneath the frozen muck and in the tailings because the early mining techniques were not sensitive to capturing and saving large nuggets. The unmined gold resource in Wade Creek, however, is probably small.

\section{Chicken Creek}

Several theories exist on the illustrious name, Chicken, for the town and creek. Spurr (1898) stated, "the creek is so named from the size of the gold, which is about that of chicken
Figure 24 LARGE GOLD NUGGET, 56.75 ounces, recovered from gravel in Wade Creek, east-central Alaska. Nugget is approximately 3 inches (7.62 centimeters) across and 2 inches (5.08 centimeters) thick. Photograph courtesy of the Jack Wade Gold Co., Tok, Alaska. 
Figure 25 AERIAL VIEW NORTH OF CHICKEN CREEK VALLEY, which is filled with mine tailings. Old town site of Chicken is at lower left corner. Myers Fork is small tributary creek draining into Chicken Creek in middle distance on left. The Taylor Highway crosses the creek just beyond lower edge of photograph. feed (corn) $)^{\prime \prime}$. Most of the present local residents prefer the story told by Foster and Keith (1969). The story is that during a town meeting in the late 1800 's the miners were discussing a name for the town, and "Ptarmigan" was suggested because there were many of these birds in the vicinity. However, no one knew how to spell "ptarmigan," so one resident offered a solution, "Oh well, then let's just call the town Chicken."

Chicken Creek is short, about 4.5 miles (7.2 kilometers) in length, drains an area of 20 square miles (51.8 square kilometers), and flows south into the Mosquito Fork about 1 mile (1.6 kilometers) below the community of Chicken (fig. 25). Gold was discovered here probably in the early 1890's, but mining didn't really flourish until 1896. Bob Matheson made the discovery (Spurr, 1898) just below the mouth of Stonehouse Creek (Mertie, 1938). Writing in 1897, Samuel Dunham (1898) described Chicken Creek as the best creek in the district with both winter and summer diggings. The creek was "practically abandoned" in 1897 because of the rush to the Klondike (Ogilvie, 1897). Because of the different local mining regulations, claims on Chicken Creek were 1,320 feet (402 meters) long compared with most other claims in the district, which were 500 feet (152 meters) in length. Spurr (1898), writing at about the same time as Dunham, described Chicken Creek as having produced very little, because development was still in the prospecting stage. Foster and Keith (1969) stated that about 175 people were living near Chicken in 1898, and that by the early 1900's many small placer mines lined the creek, which was "one of the richest gold producers in Alaska." Production from 1904 through 1907, including that from Myers Fork and Lost Chicken, Stonehouse, and Ingle Creeks, totaled about 18,835 ounces (Eberlein and others, 1977).

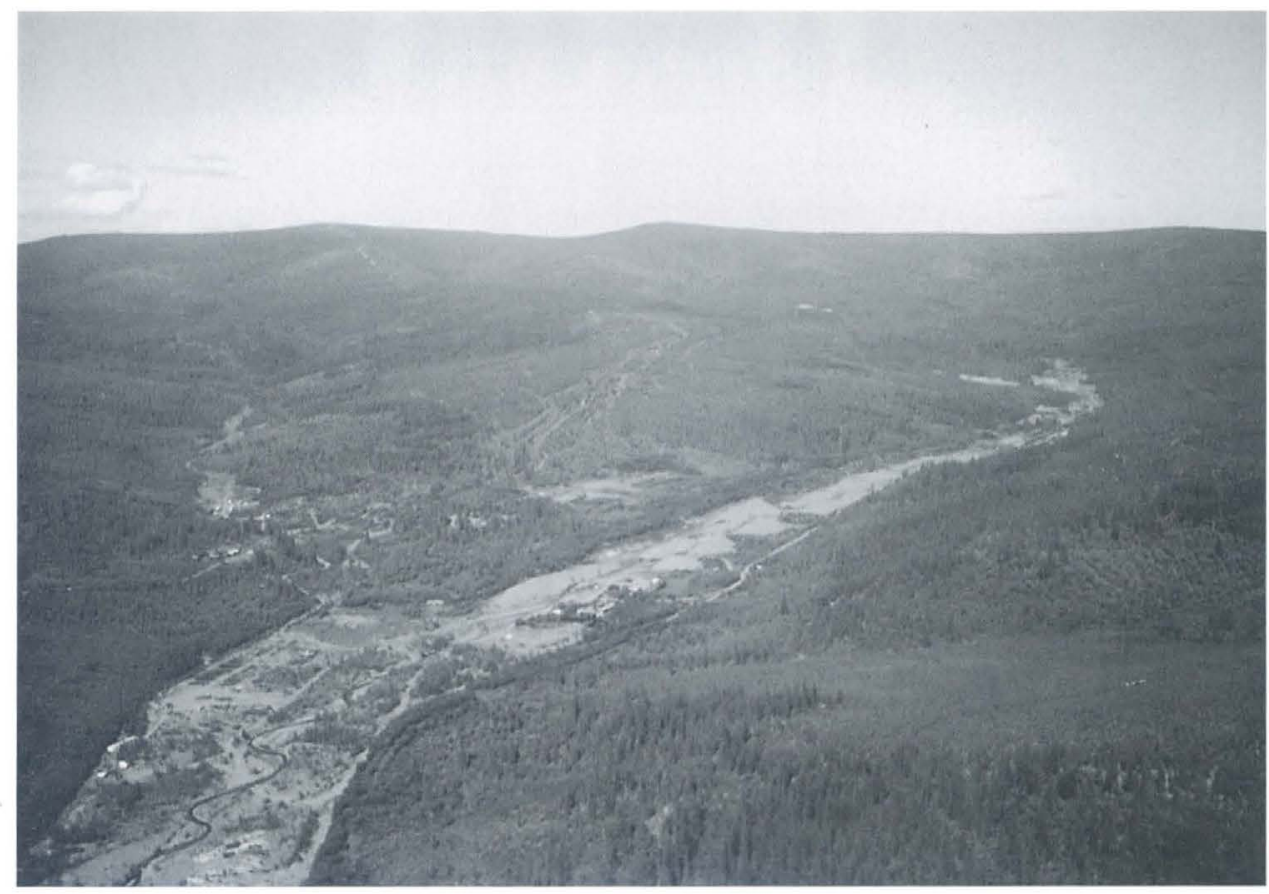

A post office was established in Chicken in 1903, and by 1906 approximately 400 people lived in Chicken and on the surrounding creeks. School was held in Chicken in the 1920 's and again in the late 1940's. Anne Purdy, a long-time resident of the area, taught school in Chicken during the 1927-28 school year and her book Tisha (authored by Robert Specht, 1976), a novel focusing on her year of teaching in Chicken, has become popular and is required reading in a number of junior high schools throughout the United States. I stayed in the original Purdy house in Chicken while gathering field data for this report. In 1949 the Taylor Highway was completed to Chicken. The site of gold mining for almost 100 years, Chicken is one of the few surviving "goldrush" towns of Alaska (fig. 26). 


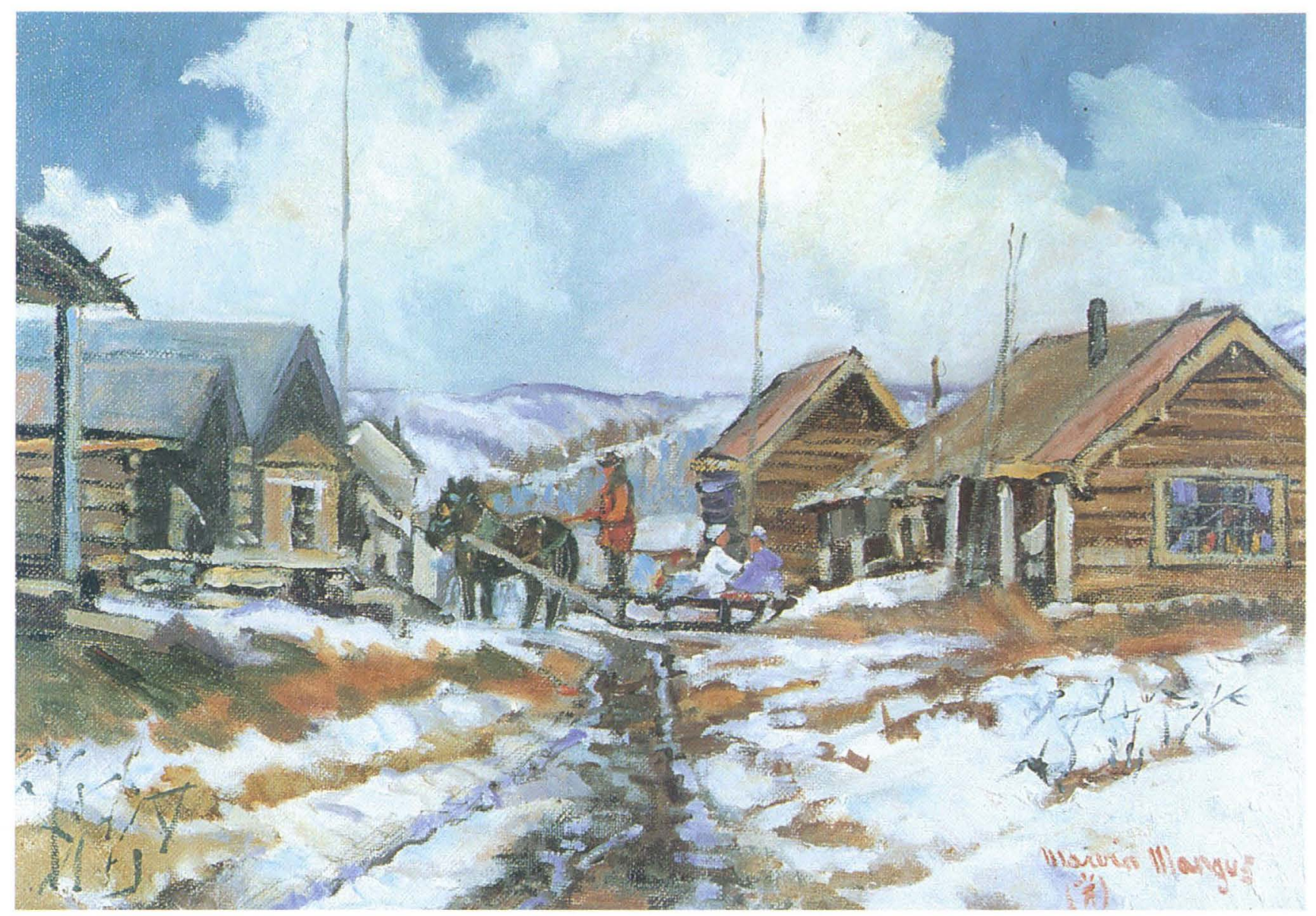

Much of the early mining on Chicken Creek was by underground methods because the rich gravel was fairly deep and frozen, and the lack of water made hydraulic mining unfeasible (Mertie, 1938). Drift and opencut mining were done during the 1927-28 season (Mertie, 1930). During the summer of 1936, mining was done by opencut, underground drifting, and small-scale hydraulic methods. In 1953 the Fairbanks Exploration Company (F.E. Co.) bought most of the claims around Chicken, as well as the town site of Chicken with all the town buildings, in anticipation of setting up a bucket-dredge operation in the creek. Surface stripping and ground thawing was completed in 1957. In 1959 a dredge was moved from near Fairbanks to the mouth of Chicken Creek and began to work its way up the creek. The dredge had a 25-foot (7.6-meter) digging arm, which was ideal for this area because bedrock was less than 25 feet ( 7.6 meters) deep after the overburden had been removed. The dredge had 3-cubic-foot (0.08-cubic-meters) buckets and was able to dig about 125 cubic yards ( 95 cubic meters) per hour. The dredge ran 24 hours a day and cleanup took place every 2 weeks. From 150 feet (46 meters) of sluice boxes on the dredge, an average of about 1,150 ounces of gold would be recovered per cleanup. Using these figures, at today's price of gold ( $\$ 350$ per ounce), it can be calculated that the dredged ground was yielding about $\$ 9.50$ per cubic yard ( $\$ 7.26$ per cubic meter). The dredge operated from June to October, from 1959 to 1967. Operations were ceased when increasing costs of equipment and labor made further dredging economically unfeasible (Naske, 1977). The dredge, appearing to be still in good condition, is located in Chicken Creek about 1 mile (1.6 kilometers) above the Taylor Highway crossing of the creek (fig. 27).

Mining has continued in Chicken Creek to this day. Hydraulic methods were in use in the 1970's (Eberlein and others, 1977), and opencut operations using draglines and bulldozers are currently being used, mostly in areas missed by the earlier dredging (fig. 28).
Figure 26 TOWN OF CHICKEN (east-central Alaska) as it probably looked during the 1920's and 1930's. Painting by Marvin Mangus. The town site was purchased and used for housing employees of the Fairbanks Exploration Company when they were dredging Chicken Creek in the 1950's and 1960 's. The town site is still owned by the F.E. Company and many of the original buildings are still present but unoccupied. 
Figure 27 THE DREDGE IN CHICKEN CREEK (east-central Alaska), which operated between 1959 and 1967. Hydraulic monitors in foreground were used to mine creek and bench gravels here during the 1970's.
Figure 28 PLACER MINING IN CHICKEN CREEK (east-central Alaska) in 1992 using a dragline to feed an elevated trommel. Taylor Highway is visible in background.

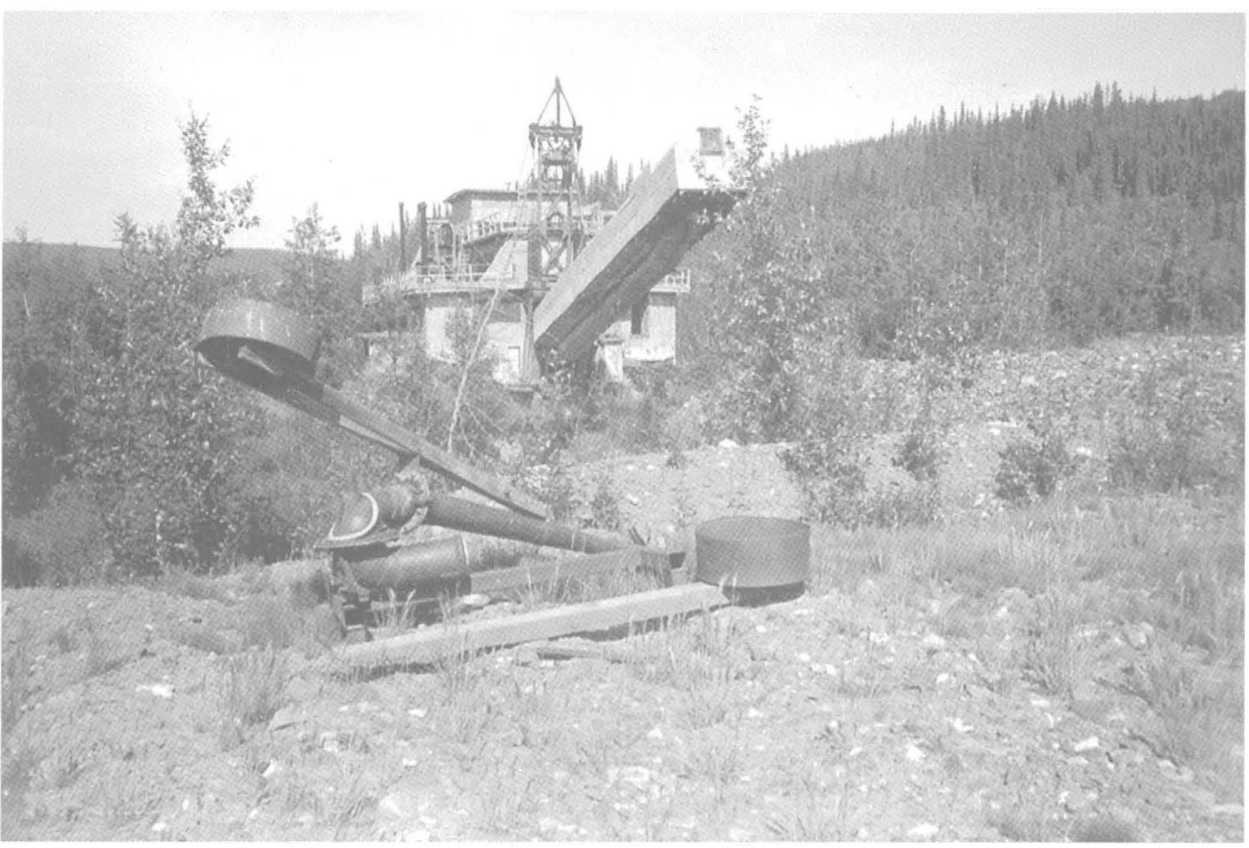

The bedrock underlying the Chicken Creek drainage is the most varied of any drainage in the Fortymile River area. In addition to the ubiquitous schist, quartzite, and granitic rock, Tertiary basalt, sandstone, conglomerate, shale, and coal are also present. Exposures of the Tertiary sedimentary rock are small and often covered so that the dredge tailings are one of the few places to see them. The coal contains amber and disintegrates when exposed to the air. Tertiary plant fossils can occasionally be found in the ferruginous sandstone and limonite-rich nodules. Pleistocene fossil horse, bison, and elephant bones can sometimes also be found among the tailings. These were originally frozen in the terrace gravel and muck deposits prior to mining. Pebble counts averaged for two locations in Chicken Creek (pl. 1, No. 21) show the following: 31 percent granite, 30 percent schist, 21 percent basalt, 11 percent quartzite, 5 percent mafic plutonic rocks, and 2 percent quartz.

The only lode gold mine in the Fortymile River area, the Purdy Quartz Mine, consists of a rich vein of gold in calcite and quartz on the ridge northeast of Myers Fork (fig. 29).

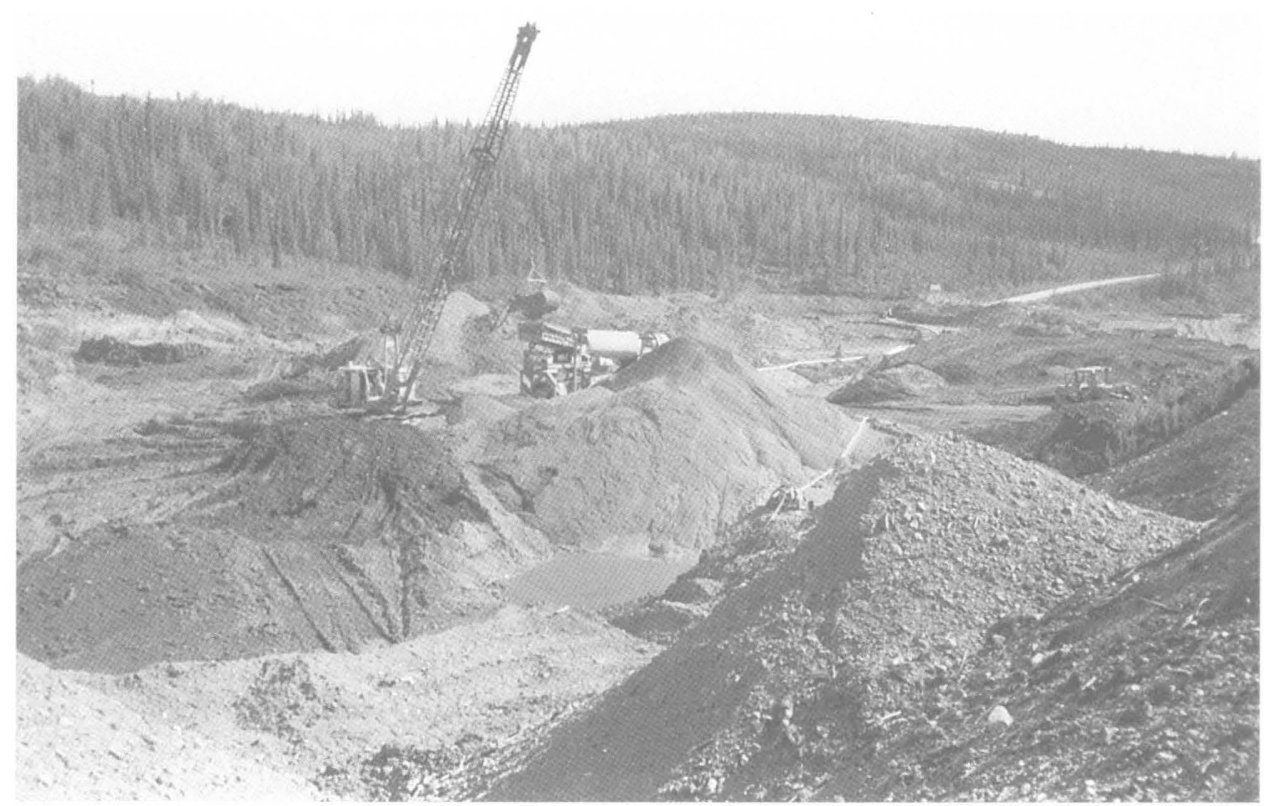




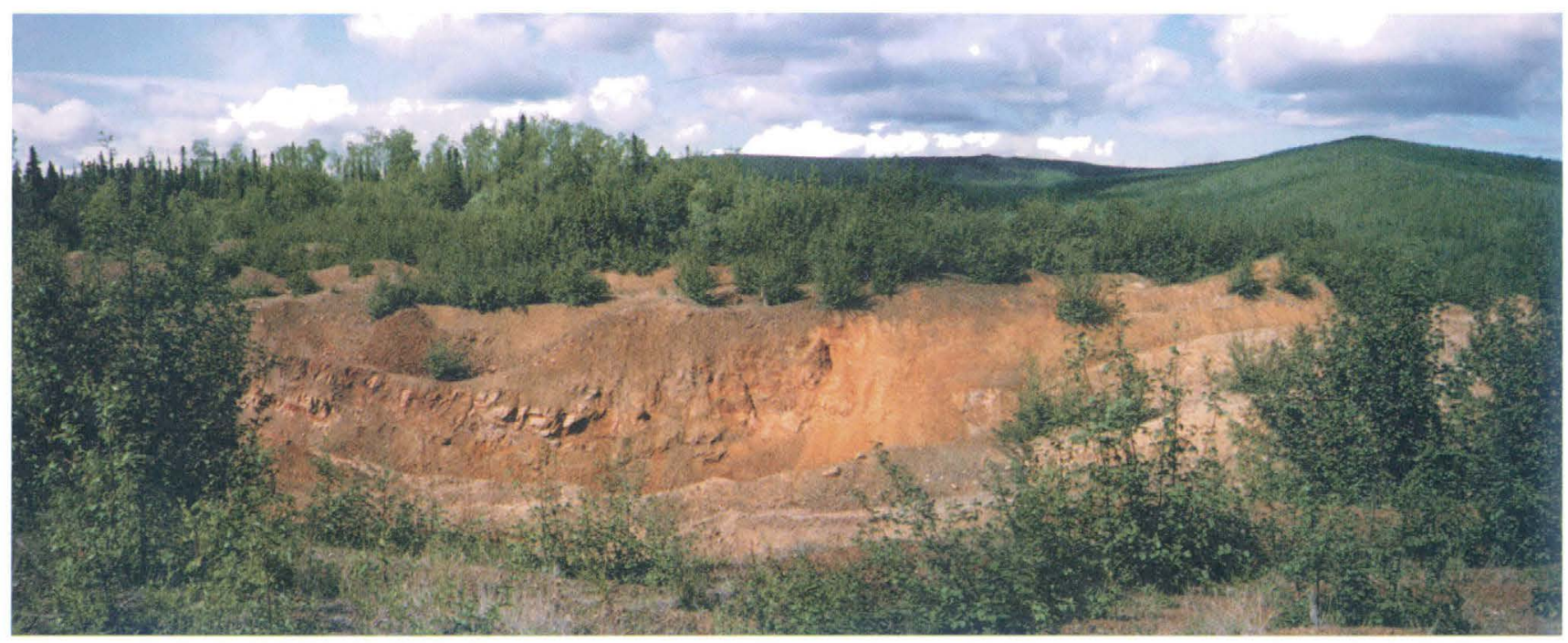

Gold was mined here to a depth of 6.5 feet ( 2 meters), where the vein abruptly terminated (Foster, 1969). Extensive prospecting failed to find the continuation of the vein.

Gravel in Chicken Creek contains subangular to subrounded clasts, but it includes a few boulders as much as 3.3 feet (1 meter) in diameter. Large well-rounded basalt boulders are occasionally seen. The gravel ranges in thickness from 6.5 to 33 feet ( 2 to 10 meters), and an overlying layer of frozen muck, 3.3 to 20 feet ( 1 to 6 meters) thick, is often present. At least two gravel-covered benches are present; a lower one about 10 feet ( 3 meters) above the creek and a high one approximately 245 feet ( 75 meters) above the creek, the gravel of which is shown on plate 1 as the Pliocene and early Pleistocene high terrace gravels unit. The low terrace is not mapped because it is too small to show at the map scale and, where present, is generally overlain by colluvium. Most of the gravel on the lower terrace has been mined. The high-level gravel, though extensively prospected, has been mined only in Lost Chicken Creek. Pebble counts from the high terrace gravel in the Chicken area are shown in table 1, samples Nos. 1,2, and 3. The high gravel-covered bench west of Chicken Creek and Myers Fork is called Virginia bench. Fine gold in very small amounts can be panned from the high-level gravels in the Chicken Creek drainage; perhaps one or two millimeter-sized (.05 inches) flakes per pan-generally not enough to justify mining at today's gold prices.

Much of the gold recovered from Chicken Creek is bright, small ( 3 to $4 \mathrm{~mm}$ ) flattened flakes, slightly rounded at the edges, and includes attached quartz (Eberlein and others, 1977). Prindle (1905) mentioned values from $\$ 0.30$ to $\$ 1.10$ per cubic yard, and no large nuggets. He reported that in 1903, 80 to 150 miners recovered about 6,000 ounces of gold from Chicken Creek. The gold was concentrated primarily on, and in the crevices of bedrock, but some fine gold was contained in the overlying 3 to 6.5 feet ( 1 to 2 meters) of gravel. Mertie (1938) described the recovery of a 1/2-ounce nugget and an average fineness of 835 for gold in Chicken Creek.

All the gravel in Chicken Creek has been mined, as indicated on plate 1. Actually, some of the dredge tailings have probably been mined more than once. This is not to say that all the gold is gone from Chicken Creek. Initial mining efforts seldom remove all the placer gold because mining methods used are not efficient enough to wash gravel completely, bedrock is not cleaned completely, or isolated pockets of gravel are left unmined. There probably exist some small pockets of unmined gravel at the valley margin and on low marginal terraces. The largest resource of gold is in the unmined Pliocene and early Pleistocene high terrace gravel, however, gold values within this unit are too low to mine profitably at today's gold prices.
Figure 29 PURDY QUARTZ MINE site located on the ridge northeast of Myers Fork, east-central Alaska. Gold occurring with calcite and quartz was mined here to a depth of 6.5 feet (2 meters), where the vein abruptly terminated. 
Figure 30 Aerial view looking west across South Fork River (east-central Alaska) up steep-sided valley of FRANKLIN CREEK. At the turn of the century, the community of Franklin, located at the mouth of Franklin Creek, consisted of about 200 people. Only a few cabins in various states of disrepair remain today.

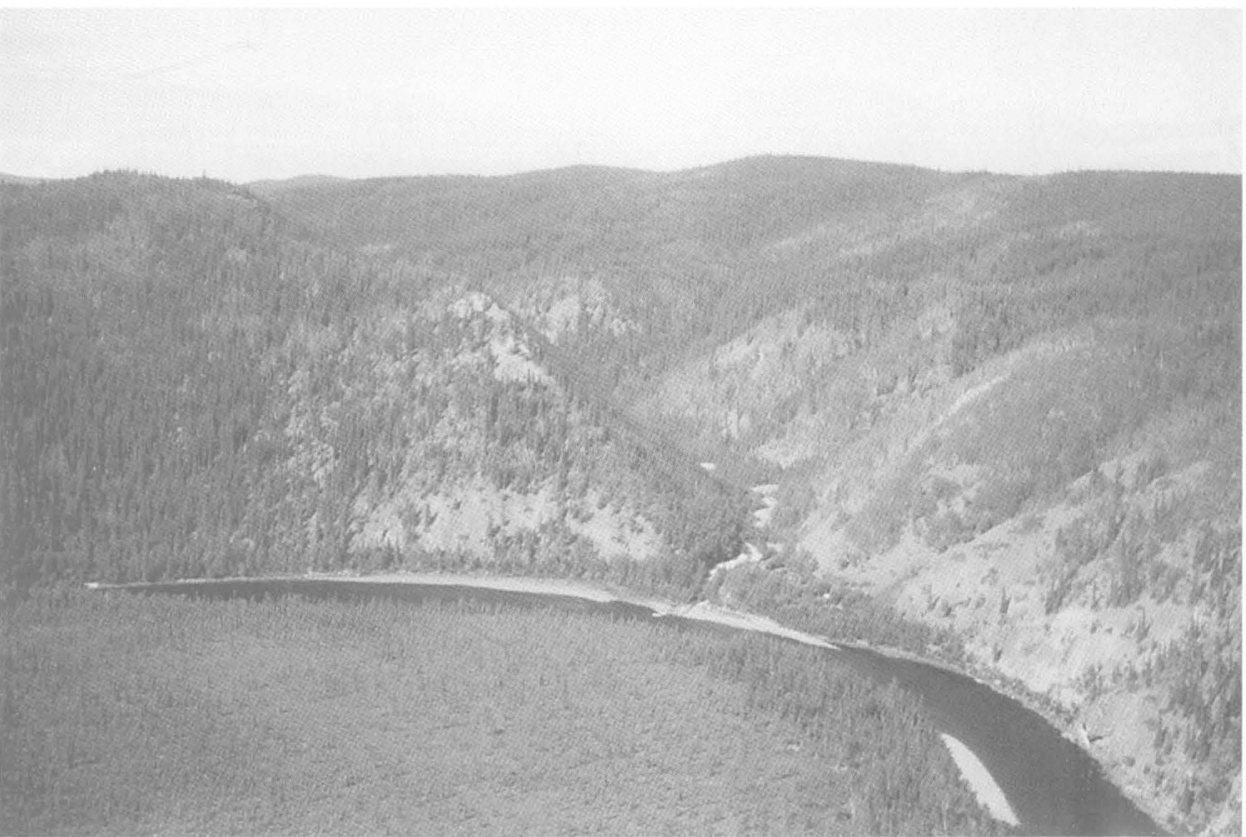

FrankLin Creek

Franklin Creek, originally called Franklin Gulch, was named for the discoverer of gold in the Fortymile area, Howard Franklin. Although it is unclear whether he was the first to find gold on Franklin Creek, he did own part interest in the discovery claim (Buteau, 1967).

Franklin Creek is really better described as a gulch, at least in its lower few miles where it flows in a narrow ravine (fig. 30). It is a short, only about 6 miles (9.6 kilometers) long, creek that empties into the South Fork between Buckskin and Napoleon Creeks (pl. 1).

Gold was discovered here in either 1886 or 1887 - Spurr (1898) mentioned both dates (p. 116 and 332). In the winter of 1887-88, Frank Buteau purchased one-third interest in the discovery claim on Franklin Creek (about 3.5 miles (5.6 kilometers) above the mouth) from Howard Franklin for $\$ 1,000$, and, according to Buteau, the claim did not pay well because it took 3 years to get his money back from mining the claim (Buteau, 1967). Dunham (1898) described good returns from Franklin Creek during the 1888 mining season, 100 men taking out "\$2,000 to $\$ 3,000 ;$; La Roche (1898) reported $\$ 4,000$ for the same season; and Spurr (1898) mentioned the presence of much coarse gold.

In 1890, Frank Leslie's Illustrated Newspaper sent to Alaska an exploring party of five men headed by a veteran correspondent. They journeyed down the Yukon and up the Fortymile to what they describe as the upper limit of mining operations, which was situated on Franklin Creek. The account of their adventures originally published in 1891 in Frank Leslie's Illustrated Newspaper states that about 40 miners were working on adjacent claims of 150 feet (46 meters) in length. The article states that the water from one miner's sluice box emptied almost directly into the sluicebox of the miner working immediately below, which indicates the close proximity of the miners. Gold was described as coarse and flaky, and the paystreak was described as 6-feet (2 meters) deep, narrow, and erratic. The best claims were paying $\$ 16$ to $\$ 17$ per day per man whereas the poorer spots yielded $\$ 6$ to $\$ 8$ per day. As the correspondent described the scene, "nearly everybody seemed to be making a living, but a few were doing better" (Wells and Sherman, 1974). Although the accepted mining rules in Alaska at this time permitted claims of 1,500 feet (457 meters) in length, because Franklin Creek was so short and narrow, it was agreed to by the local min- 
ers that shortened claims would be required on this creek; thus more people could mine on the creek.

The topographer, C.E. Griffiths, enroute to Eagle City in 1899 stopped at Franklin Creek and reported, "a number of men at work with sluice boxes, although water for sluicing was very scarce." He further stated that "the Gulch had been mined for a great many years and some snug fortunes have been taken out of it" (Griffiths, 1900).

Because of the small drainage basin of Franklin Creek adequate water for mining has always been a problem. Some winter drifting was done during the first decade of mining on the creek and in 1903-04 the bar at the mouth of the creek was worked with the aid of a steam-thawing apparatus. Prindle (1905) reported about 20 days of good water for sluicing and 60 days for shoveling in.

The community of Franklin was established at the mouth of the creek (fig. 30) and was inhabited continuously from 1886 to 1948 . The telegraph connected the community to the outside, a post office was in operation from 1902 to 1945, and a school was established in the late 1920's. Anne Purdy also taught school here for a short time. A roadhouse in operation until 1945 was the focal point of social life in the area with its Sunday dinners and dances. Mail day ( 3 times a month) as well as Sunday activities at the roadhouse attracted nearby residents. Money was not commonly used to pay for food and services in early-day Franklin. Meals at the roadhouse were $\$ 1$ and were often paid for with gold dust. A blacksmith shop was located across the South Fork River from the community of Franklin and helped support a drift-mining operation. A cable car carried men and supplies across the river. An airstrip was constructed on the high ridge across the South Fork from Franklin; its position is still shown on the map (pl. 1), but it is no longer maintained and cannot be used. At its peak, sometime in the late 1800's, the population of Franklin approached 200 (Haynes, 1976).

Mertie (1938) described Franklin Creek as the oldest producing creek in the Fortymile District. However, by the time of his visit all the best ground was mined out, and the current operations were confined to working the lean, deep gravels on the edges of the pay streak. Mining was the shoveling-in method with some ground sluicing. A disastrous flood destroyed most of the mining developments in 1935, and little mining has occurred on the creek since the roadhouse and post office closed in 1945.

Except for the headwaters of Franklin Creek, which are in granitic rock, quartzite, . and schist of the gneiss, schist, amphibolite, and marble (bedrock) unit are the predominant rock types through which Franklin Creek flows (pl. 1). Quartz veins cut the foliation of the metamorphic rocks. A pebble count near the mouth of the creek (pl. 1, No. 22) gives the following: 42 percent schist, 28 percent marble, 20 percent granite, and 10 percent gneiss. Boulders of basalt as much as 10 inches ( 25 centimeters) in diameter are occasionally present, however, no basalt has been mapped in the drainage basin. Spurr (1898) reported the presence of small boulders and pebbles of olivine basalt, which the early miners called "gold rock." Wherever the "gold rock" occurs in the gravel there was sure to be gold in quantities, or so thought the miners.

The gravel in Franklin Creek is too small in areal extent to be shown at the scale of the map (pl. 1). The gravel deposits are generally less that 50 feet (15 meters) wide on the narrow floor of Franklin Creek. The subrounded to subangular boulders are as much as 3.3 feet ( 1 meter) in diameter, but they are more commonly less that 1.6 feet ( 0.5 meters) across. Thickness ranges from 3 to 30 feet ( 1 to 9 meters). The gradient in the lower 3 miles ( 5 kilometers) of the valley is high-140 feet to the mile ( 27 meters per kilometers), whereas the gradient of the upper valley is much less. These conditions suggested to Mertie (1938) that Franklin Creek is far from "graded" and is, rather, in the process of adjusting to a lower base level. Mertie thought this was probably a result of rejuvenation of the Fortymile River. No gravel terraces were observed along Franklin Creek. 
Figure 31 AERIAL VIEW LOOKING WEST DOWN THE LOWER PART OF NAPOLEON CREEK to its junction with the South Fork, east-central Alaska. Placer mining tailings are evident in the creek bottom and on the high bench on the right margin of the photograph.
Franklin Creek has been known as a producer of coarse, angular gold. Spurr (1898) described the gold found here as "nuggety," with 1/4-ounce-size pieces common, and very little fine or flour gold. He stated that, "from Franklin Gulch have been taken out the two largest nuggets discovered in the Yukon District." A 30-ounce nugget was described as flat and oval shaped with the longest dimension 4.5 inches (11.4 centimeters) and 0.8 to 1 inch ( 2.2 to 2.5 centimeters ) thick. This nugget was found 2.5 miles ( 4 kilometers) above the mouth of Franklin Creek. Another nugget of 14 ounces was also recovered in the early years of mining on the creek. The coarse gold commonly has attached vein quartz. The gold in Franklin Creek has been concentrated on and within fractures of the bedrock and within the lower 1.6 feet ( 0.5 meters) of gravel. Prindle (1905) described the richest gravel as possessing a value of $\$ 50$ to $\$ 90$ per cubic yard ( $\$ 30$ to $\$ 69$ per cubic meter) and the "pay" extending across the entire width of the creek bottom. The average annual production from the creek in the years just prior to Prindle's visit in 1904 was $\$ 8,000$. Mertie (1938) stated that the fineness of gold from Franklin Creek was at least as great as 820 .

Other than on a very small scale, it is doubtful that there has been any recent mining in Franklin Creek. The creek contains such a small amount of gravel it would seem that all the exposed deposits have either all been mined, or, at least thoroughly prospected. The gold resource remaining is probably minimal.

\section{Napoleon Creek}

It is generally believed that this creek was named after a French-Canadian miner who, on occasion, imagined himself to be Napoleon Bonaparte. He was, probably, one of the earliest miners on the creek (Haynes, 1976).

Napoleon Creek flows in a southwest to west direction into the South Fork River about 5 miles ( 8 kilometers) above Franklin Creek and 2 miles ( 3.2 kilometers) below Walker

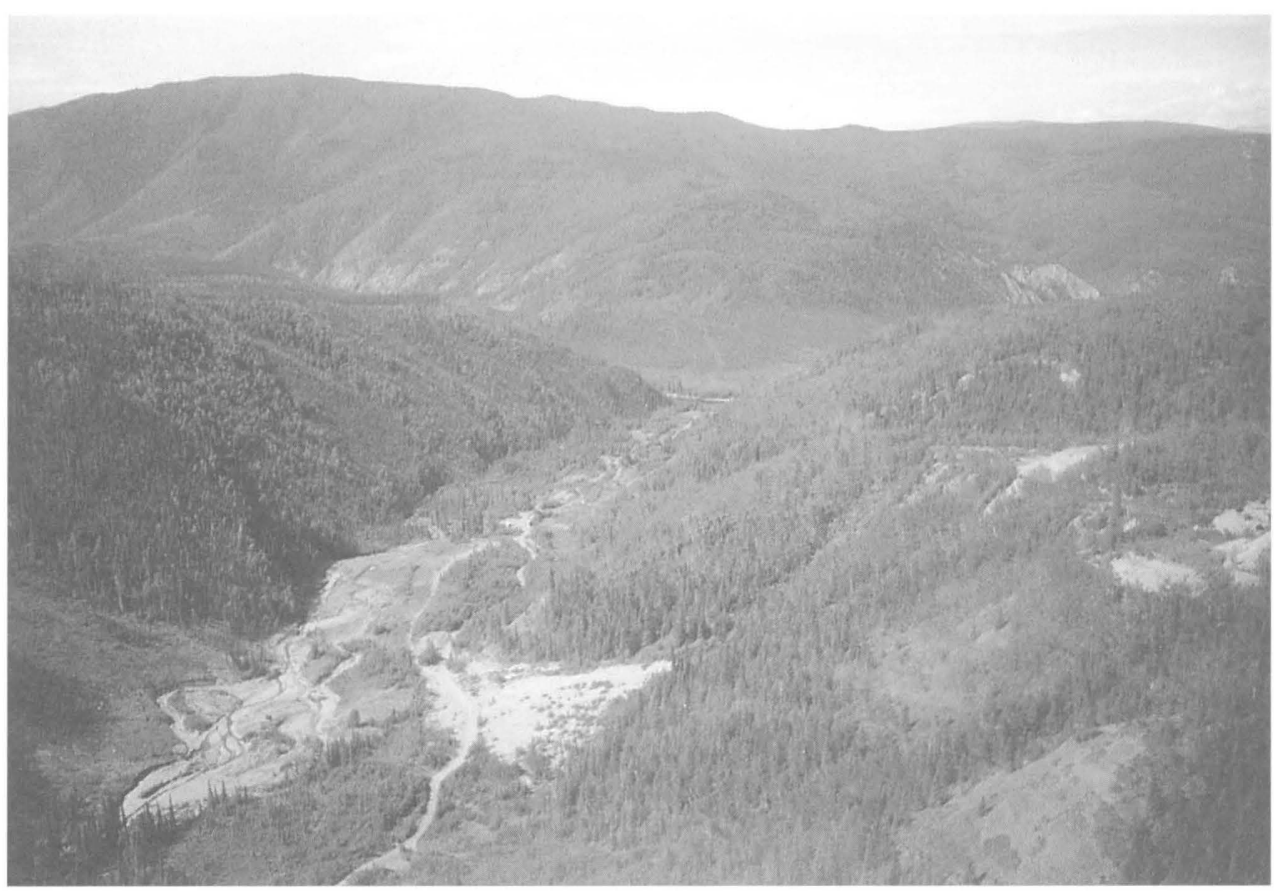

Fork (fig. 31). Only parts of the lower 3 miles (4.8 kilometers) of the creek have been mined.

A Mr. Aylward discovered gold near the mouth of Napoleon Creek in 1893 and reportedly recovered, in the first three years of mining, about 650 ounces of gold from his two claims that extended 2,320 feet ( 707 meters) up from the creek's mouth. Other miners working farther up the creek recovered only about 60 ounces from their claims during the same interval (Spurr, 1898).

The early mining in the floodplain gravels of Napoleon Creek was by the shoveling-in method. Mertie (1938) described the mining in 1936 as small-scale hydraulic and shoveling-in operations on low benches that are scarcely visible as surface features. Two levels are noted-one 25 to 30 feet ( 8 to 9 meters) and another about 60 feet (18 meters) above the creek level. Approximately 6,200 ounces of 
gold had been recovered from claims on Napoleon Creek by the time of Mertie's visit in 1936. Mining using dragline-bulldozer-hydraulic combinations were active in the 1950's (Naske, 1977). Mining on the creek and within gravels on the high bench to the north has been sporadic during the past 40 years. Some ground stripping was evident in the middle and upper parts of the northern fork of Napoleon Creek in the early 1990's.

Similar to Chicken Creek, a sizable part of Napoleon Creek's drainage is underlain by Tertiary sedimentary rocks and basalt. The lower 1.2 miles ( 2 kilometers) of Napoleon Creek flows across beds of conglomerate, sandstone, shale, and coal dipping $15^{\circ}$ to $40^{\circ}$ in a nearly upstream direction (Foster, 1969). The high terrace on the north side of the creek is underlain by basalt. The middle part of the drainage is underlain by the quartzite and schist of the gneiss, schist, amphibolite, and marble unit, and granitic rocks are present in the headwater region ( $\mathrm{pl} .1$ ). A pebble count in Napoleon Creek upstream from the outcrops of the Tertiary sedimentary rocks (pl. 1, No. 23) shows: 32 percent schist, 30 percent quartzite, 18 percent granite, 14 percent greenstone, 4 percent basalt, and 2 percent quartz. The high percentages of schist, quartzite, and granite here are similar to those found in the high terrace gravels on the north side of Napoleon Creek (table 1, loc. no. 5). The higher percentage of granite in the terrace gravels may reflect the more extensive exposure of granitic rock in the drainage basin of the ancestral Napoleon Creek. A large whitish-colored fan of recent origin is present in the Napoleon Creek valley at the base of the steep slope leading up to the high terrace on the north side of the valley (fig. 31). This fan is white because of the high percentage of granite clasts present, which have been washed down from the high terrace by former mining operations.

The gravel in Napoleon Creek is composed of subrounded, rounded, and subangular clasts as much as 3.3 feet ( 1 meter) across. Thickness ranges from 8 to 18 feet (2.4 to 5.5 meters) and about 3 to 6.5 feet ( 1 to 2 meters) of frozen muck is commonly present overlying the gravel. In the lower part of the creek, the gravel has been mined over a width of 150 feet ( 46 meters) (fig. 31). The gravel on the low benches that was mined in the 1930's was 2 to 10 feet ( 0.6 to 3 meters) thick and about 30 feet ( 9 meters) wide. The gravel on the high 560 -foot (170-meter) terrace to the north possess subrounded cobbles and boulders as much as 1.5 feet $(0.5$ meter) in diameter and are approximately 130 feet ( 40 meters) thick.

Gold has been found concentrated mainly on the bedrock surface and in cracks and cavities in the bedrock in Napoleon Creek as well as on adjacent low terraces. It is irregular and coarse with nuggets as much as $1 / 2$ inch ( 1.2 centimeters) in diameter not uncommon, and its average fineness is 870 (Eberlein and others, 1977). The terrace that is 560 feet (170 meters) above Napoleon Creek on the north yielded 1,300 ounces of gold from an area not much larger that $1 / 4$ acre (0.10 hectare) (fig. 6) mostly in small pockets on basalt. Using $1 / 4$ acre for the area mined and a thickness of gravel of 130 feet ( 40 meters), which is about the average thickness of the unmined gravel here, a value of $\$ 8.50$ per cubic yard ( $\$ 6.50$ per cubic meter) can be computed. Unfortunately for miners, the gold is not uniformly distributed throughout the "high terrace gravels" (see "High Terrace Gravel" section).

Gold is still being mined from Napoleon Creek and small amounts probably remain in the upstream parts of the creek. Likewise, the high terrace gravels would seem to contain some gold, although I suspect these terraces have been thoroughly prospected owing to the known presence of the rich pocket of gold that has been mined from the gravel here. Suction dredging has been successful at the mouth of Napoleon Creek.

\section{Lost Chicken Creek and lost Chicken Hill}

Lost Chicken Creek is the very short 6,200-foot (1,900-meter), steep-sided stream that flows southeast into the South Fork River about 2.5 miles ( 4 kilometers) below the mouth 
Figure 32 AERIAL VIEW LOOKING WEST AT UPPER, MINED PART OF LOST CHICKEN CREEK (eastcentral Alaska). Taylor Highway makes a sharp curve where it crosses the creek and mined area. Chicken Creek drainage is in the background, and Lost Chicken Hill rises left of mined area in middle distance. of Chicken Creek (fig. 32). The name "Lost Chicken" seems to have been adopted for the hill and short creek because of the sizable amount of placer gold that was discovered here, but which was subsequently "lost" or remained undiscovered for several years following initial discovery of gold on Chicken Creek. Miners initially believed that the pay streak at Lost Chicken was a continuation of the pay streak in Chicken Creek that is present approximately 300 feet (91 meters) lower. However, it seems that the gold-rich deposits mined on Lost Chicken Hill and near the head of Lost Chicken Creek were part of the high terrace gravels system and, therefore, much older than those present in the floodplain gravel of Chicken Creek.

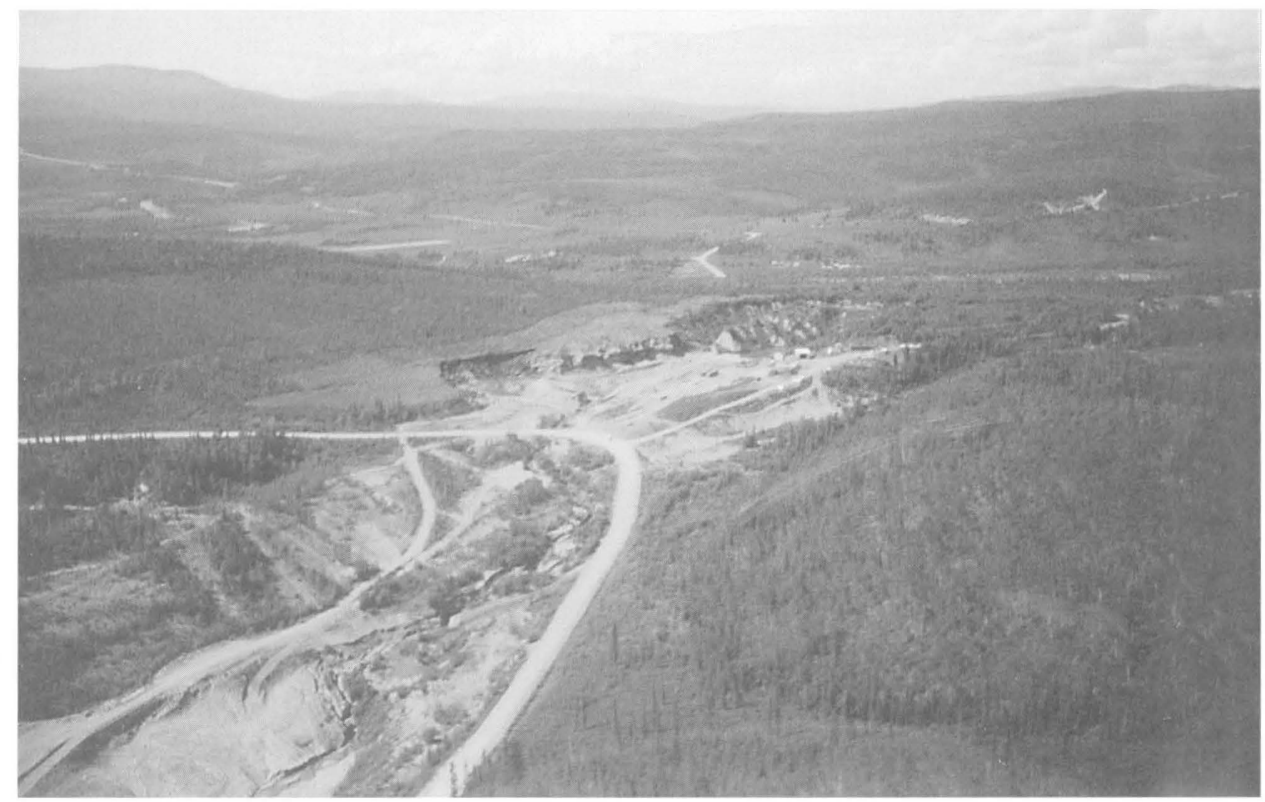

Gold was discovered here either in 1895-96 (Eberlein and others, 1977) or in 1901 (Prindle, 1905). Claims originally were located on the bench at the head of Lost Chicken Creek and gold was found at a depth of 33 feet (10 meters). The area was staked because it was the only open ground in the area with any placer potential. This bench subsequently became known as Lost Chicken Hill and drifting was the mining method used. Eventually it was discovered that the pay streak continued on down the west side of the valley of Lost Chicken Creek and mining since has been mostly confined to the valley of Lost Chicken Creek (fig. 32). Beginning around the 1930's, hydraulic methods were used to mine the gravel. Water for hydraulicking was brought by ditch from the eastern headwater tributaries of Chicken Creek and stored in a reservoir near the head of Lost Chicken Creek. From sometime in the 1960's through 1992, hydraulic methods were used to melt the overlying frozen muck (fig. 8) prior to mining the gold-bearing gravel in opencuts with bulldozers.

The gravel in the Lost Chicken Creek drainage generally rests on a weathered surface of altered diorite and quartz diorite near the margin of a pluton (Foster and O'Leary, 1982). Rocks that have been contact metamorphosed may also be present. A pebble count (table 1, No. 3) of the creek gravel indicates the preponderance of granite, schist, and quartzite clasts. Near the head of Lost Chicken Creek, the gravel may be underlain by Tertiary sedimentary rocks such as conglomerate, sandstone, shale, and coal (Prindle, 1905). Gold in submicroscopic amounts has been detected in sheared and altered diorite within a bedrock cut of the placer workings here. The location is about 6,500 feet (1,980 meters) upstream from the mouth of the creek. The yellow and orange-brown dioritic rock type possesses calcite-filled fractures and contains sulfides. Two of six grab samples contained 0.10 parts per million (ppm) gold, as determined by atomic-absorption methods (Foster and O'Leary, 1982). A volcanic ash bed (tephra) in a peat and silt section (fig. 9) overlies the 
high terrace gravels at Lost Chicken Creek and was dated at 2.6 to 1.7 Ma (Naeser and others, 1982). This bed is described in the "High Terrace Gravels" section.

The presence of a moderately large suite of Pleistocene vertebrate fossils within the silt, sand, and gravel of Lost Chicken Creek has resulted in some rather detailed studies of these deposits. The Pleistocene deposits along Lost Chicken Creek consist of approximately 75 feet ( 23 meters) of rounded, loosely cemented, limonitic-stained gravel overlain by 30 to 50 feet (9-15 meters) of brown sand and sandy gravel, silt, and peat. Nine stratigraphic units from these deposits have been described (Porter, 1985). From these units, 1,055 vertebrate and invertebrate fossils have been recovered ranging in age from $1400 \mathrm{yr}$ B.P. to more than $50,400 \mathrm{yr}$ B.P. The fossil assemblage includes bones of rare birds, wolverines, an extinct American lion, collared lemming, Saiga antelope, and a large Pleistocene cat. Human presence is implied sometime prior to $11,000 \mathrm{yr}$ B.P. by the evidence of worked bone fragments (Porter, 1985; Whitmore and Foster, 1967). The gravel consists of subrounded to subangular boulders, cobbles, pebbles, and sand with clasts rarely larger than 1.5 feet $(0.5$ meters). The gold-bearing gravel in the immediate Valley of Lost Chicken Creek is probably Pleistocene and Holocene in age, whereas the gravel that was mined in the early years of the 20th century on the flanks of Lost Chicken Hill is probably the high terrace gravels of Pliocene and early Pleistocene age.

The bulk of the gold found on Lost Chicken Creek has come from the lowest $1 \mathrm{~m}$ of gravel and within fractures and eroded and weathered irregularities in the bedrock. The gold occurs mostly as small flattened pieces and rarely as large nuggets-a 1.5-ounce nugget was recovered in the early 1930's (Mertie, 1938). Fineness averaged from seven samples is 842 (Mertie, 1938). Mertie (1938) felt there was a local gold source on Lost Chicken Creek. Foster and O'Leary (1982) concluded that "some Lost Chicken placer gold is probably very locally derived from sheared mineralized diorite and quartz diorite, but the differences in appearance and composition of the gold and the physiographic aspects of Lost Chicken Creek suggest that much of it has been derived elsewhere and has a long and complex history." Foster and O'Leary (1982) had five gold samples from Lost Chicken Creek analyzed for trace elements by the semiquantitative six-step spectrographic method. Most elements were not detected, but of those that were the results were quite variable: silver 20,000 to $100,000 \mathrm{ppm}$; copper 70 to $1,000 \mathrm{ppm}$; and palladium 0 to $7 \mathrm{ppm}$; such varying amounts of trace elements in so few samples led them to conclude that the gold was derived from multiple sources.

The potential for remaining, unmined placer gold in the Lost Chicken Creek area would seem to exist west of the Taylor Highway in the high-level terrace gravel near the head of the creek. Early drift mining and later opencut mining has certainly removed some of this resource and a thorough sampling (drilling) program would be needed to ascertain the remaining resource.

\section{Canyon Creek}

Canyon Creek, of which there are 44 in Alaska, was named sometime prior to 1894 (Constantine, 1895), probably for its rather straight, steep-sided valley. Although it is not known when gold was first discovered here, it was being mined by 1893 by "a few men," and yielded " $\$ 12$ to $\$ 14$ per day" (Constantine, 1895).

Information on the mining history of the creek is scanty. Miners in 1909 and 1910, 3 miles below the mouth of Squaw Gulch, used a scraper drawn by a 45-horsepower steam boiler. Fifteen cubic yards (11 cubic meters) per hour could be moved using this method. Eight men operated the mine, which involved washing a 7-foot (2.1-meters) thickness of gravel and 2 feet $(0.6$ meter) of bedrock. A plowlike implement operated by the same line of cables that hoisted the gravel to the sluice was used to break up the bedrock. The Boundary Dredging Company established a bucket dredge on Canyon Creek in 1938 and had suc- 

NORTHEAST ACROSS DOME Little Miller Creek is the rather straight tributary coming in from the north. Hydraulic pits developed in the bench gravels are evident on both sides of Little Miller Creek. The tailings from these pits are the broad unvegetated gravel fans grading down to Dome Creek.
Figure 33 AERIAL VIEW LOOKING CREEK VALLEY, east-central Alaska.

cessful seasons during 1939 and 1940 (Smith, 1939, 1942). The Yukon Placer Mining Company mined with a bucket dredge in 1948 (Naske, 1977). Mining has been sporadic on the creek during the last 40 years. In the 1991 and 1992 seasons there were at least two operations mining gold along the creek ( $\mathrm{pl} .1$ ); one of those was mining a terrace gravel on the upstream tributary, Woods Creek.

Bedrock in the Canyon Creek drainage is almost entirely composed of the quartziteschist and gneiss of the gneiss, schist, amphibolite, and marble unit. A small body of granitic rock crops out along the east side of the creek in its lower reaches (pl. 1). Prindle $(1908 ; 1909)$ reported that gold was "found in place on the ridge south of Kalamazoo Creek," a tributary of Canyon Creek. It is unclear to which creek he was referring to because there is no creek on the presently existing maps with this name. It may be the same creek that is named Kal Creek on the map, a tributary of Squaw Gulch (pl. 1). Prindle also described specimens of rusty vein quartz from an outcrop of brecciated quartzite that contain free gold. Prindle described the outcrop as consisting of vein quartz, quartzite, and schist 1,000 feet (305 meters) long by 50 to 100 feet ( 15 to 30 meters) in width. He stated that the local miners believed the placer gold in the creeks here was derived from this locality.

The gravel in Canyon Creek consists of subrounded to subangular clasts and contains some boulders that are rarely larger than 1.5 feet ( 0.5 meters) in diameter. The upper valley roughly is 200 to 300 feet ( 60 to 90 meters) in width, and the floodplain gravel of the upper valley has been mined at least once. Mertie (1938) described "high auriferous gravel along the west bench of Canyon Creek." Pebble counts from two localities along the creek (pl. 1, No. 24) give the following averages: 33 percent quartz, 14 percent granite, 40 percent schist, 6 percent quartzite, and 7 percent gneiss. The gravel in Canyon Creek is 6.5 to 16 feet ( 2 to 5 meters) thick. Information on gold size and values is not available

The gravel in the upper half of Canyon Creek has been thoroughly mined, however, the wider, lowest 3 miles ( 4.8 kilometer) of the creek apparently contains unmined gravels. The tributary, Squaw Gulch, has produced gold and should be considered a source for gold in lower Canyon Creek. A mine was in operation on Canyon Creek about 1.2 miles (2 kilometers) below the mouth of Squaw Gulch in the summer of 1992.

\section{DOMe CREeK}

Dome Creek flows in a general southwest direction and drains the west side of Fortymile Dome (just off the map to the northeast) from which it most likely derived its name. The mouth of the creek can be seen from the Taylor Highway where it empties into O'Brien Creek about 3 miles

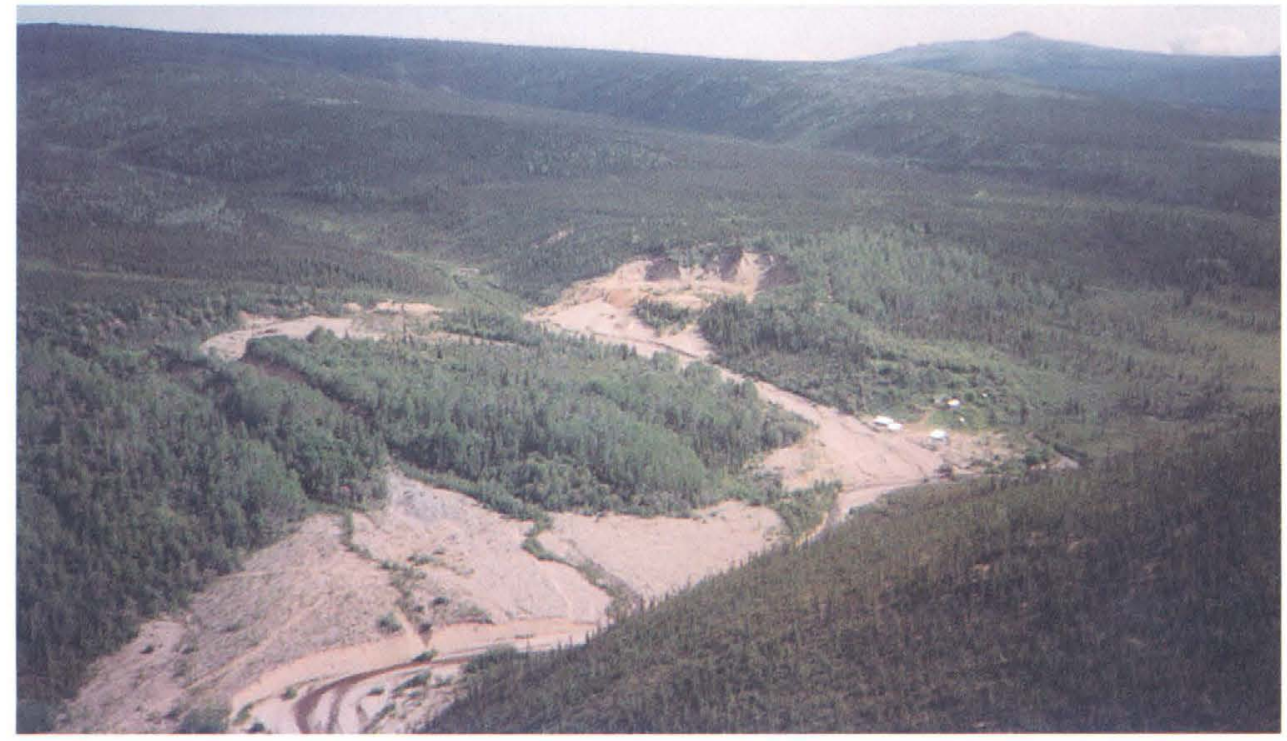
(5 kilometers) north of the Fortymile River (pl. 1).

Gold was discovered on Dome Creek at the mouth of Little Miller Creek tributary (fig. 33) in 1893 by miners who had packed over the divide from Nuggett Gulch 7.4 miles (12 kilometers) due south (Prindle, 1905). The earliest mining took place at this site and along the two lower claims on Little Miller Creek. Mining in this area proved lucrative and 
the original discoverers soon left the country with their new-found wealth (Mertie, 1938). It was soon realized that the bench gravel along the north side of Dome Creek through which Little Miller Creek flows was the source of gold, and mining soon began on these benches. The mining of the bench gravel was done using hydraulic methods, and the water was brought by ditch a distance of 8 miles (13 kilometers). Details of the chronology of mining are scanty, but it probably went on sporadically during much of the 20th century. In 1977 there was a small mining operation near the mouth of Dome Creek (Eberlein and others, 1977), and mining has been sporadic up to the present.

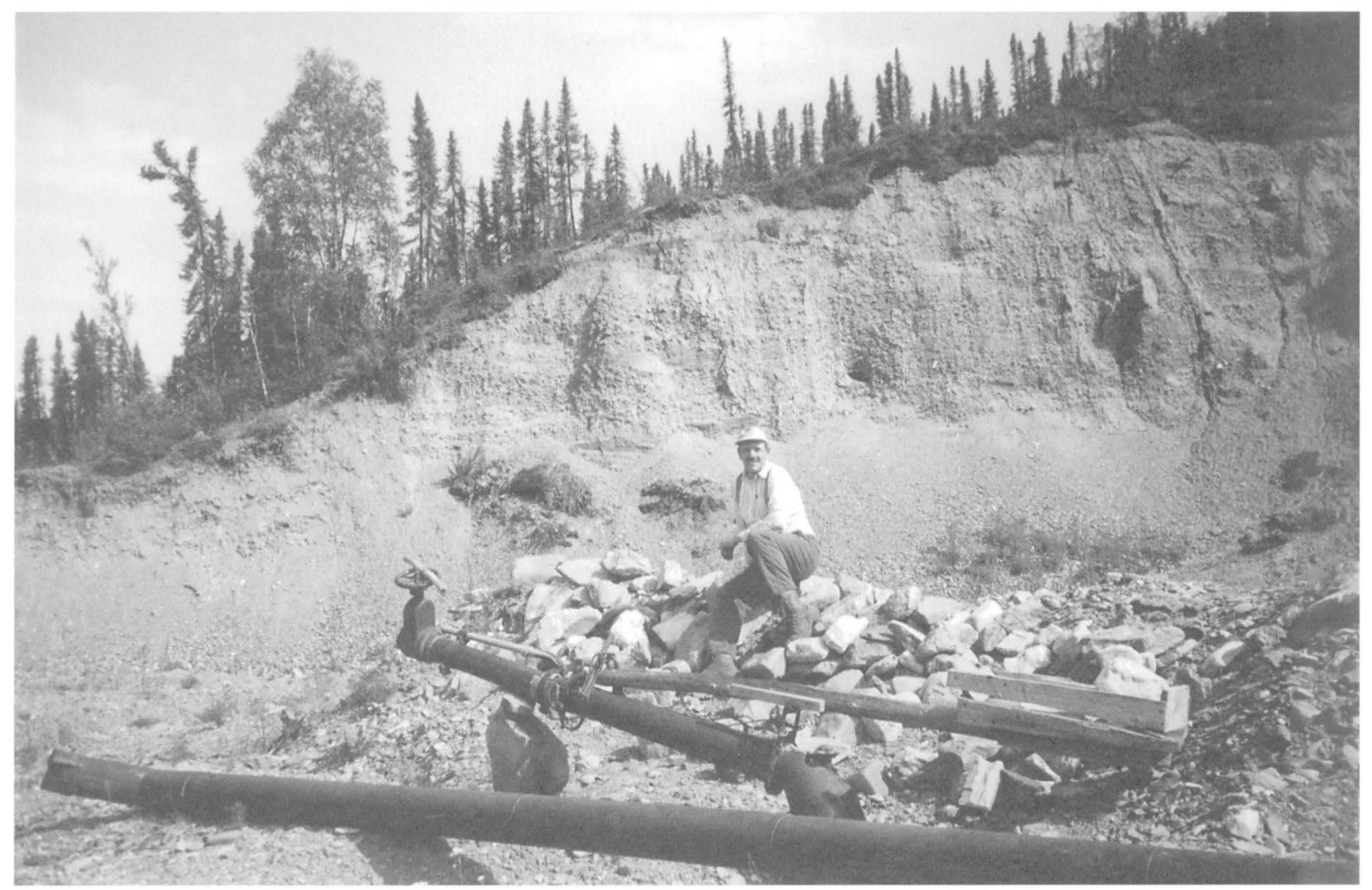

Bedrock in the Dome Creek drainage is almost exclusively quartzite, schist, and gneiss of the gneiss, schist, amphibolite, and marble unit (pl. 1) with a very small area at the headwaters of some north-flowing tributaries underlain by granitic rock (pl. 1). Mertie (1938) described the bedrock, where exposed by mining on the benches, as possessing numerous shear zones filled with greenish gouge, some of which consists of granulated vein quartz and pyrite.

Almost all mining along Dome Creek has been within the bench gravel. Small, isolated high terrace gravels are present along the lower 3 miles (5 kilometers) of the creek. Here the benches are about 390 to 490 feet (120 to 150 meters) above the creek and the gravel on the benches is just over 3 to 13 feet ( 1 to 4 meters) thick. There has been no mining at these localities. Near Little Miller Creek, the benches are considerably closer in elevation to the creek, only about 100 to 150 feet (30 to 45 meters) above the creek. The gravel is composed of well-rounded to subangular clasts with boulders as much as 3.3 feet (1 meter) in diameter. Most of the gravel is pebble and cobble (less than 2 inches or 5 centimeters in diameter) in size and 30 to 80 feet (10 to 20 meters) thick (fig. 34). Wellrounded quartz boulders are concentrated near the base of the gravel. A pebble count (table 1 , No. 7) from gravel making up the bench gravel shows the high concentration of quartz,
Figure 34 HYDRAULIC PIT ON NORTH SIDE OF DOME CREEK near its junction with Little Miller Creek (east-central Alaska). Thirty to 60 feet (9 to 18 meters) of cobble and pebble gravel is shown here in the pit walls and the larger quartz boulders (near center of photograph) washed out of the lower part of the gravel section. A hydraulic monitor with its counterbalance is in foreground. 
schist, and quartzite. The bench gravel in the middle reaches of Dome Creek is all on the north side of the creek and extends back from the creek 3,300 to 5,000 feet $(1,000$ to 1,500 meters) and along the creek for about 6 miles (10 kilometers) (pl. 1). Mertie (1938) described the bedrock bench surface as having a definite rim along the south side and sloping gently northward. Muck overlying the bench gravel has yielded remains of mammoth, bison, and other vertebrates (Mertie, 1930).

Information on the gold and values comes from Mertie's (1938) visit in 1937 because mining of the bench gravels was going on then. He described a cleanup that yielded about 1,400 ounces of gold from about 193,000 cubic yards (147,567 cubic meters) of gravel; approximately $\$ 2.50$ per cubic yard ( $\$ 1.91$ per cubic meter) at today's gold prices. The gold was found mainly on or near bedrock, but some fine gold was contained throughout the gravel section, which suggested to Mertie that "some of the gold may have traveled considerable distance." The gold was described as bright yellow, mostly fine grained, and vein quartz was commonly attached to the larger pieces. The largest fragment found during Mertie's visit was 7 grains ( 480 grains $=1$ ounce) and its fineness was determined to be 885 .

Although there remains abundant unmined bench gravel on Dome Creek (pl. 1), the low unit gold value of the gravels would require a mining method capable of washing large quantities of gravel cheaply, which would mean the hydraulic method. Environmental restrictions make this method unfeasible today.

\section{Souaw Gulch and Baby Creek}

Squaw Gulch is a tributary of Canyon Creek and Baby Creek is a tributary of Squaw Gulch (pl. 1). It is not known when gold was discovered here, but both drainages were named by prospectors by 1896 (Spurr, 1898; Orth, 1967) and mining was underway by the early 1900 's.

Prindle (1905) described Squaw Gulch in 1903 as the "most important tributary" of Canyon Creek-he was referring to its importance as a gold-producing creek. Its narrow V-shaped valley is incised 1,500 feet (450 meters) into the topography. Prindle reported that ditching had been done and dams built, but only a few men were on the creek in July of 1903. The best values obtained from mining the placers here averaged $\$ 40$ per cubic yard (\$30 per cubic meter).

In 1912 on a claim below Baby Creek six men operated a bottomless steam scraper of 3/4-cubic-yard ( 0.57 cubic-meter) capacity powered by a 40 -horsepower boiler. The muck was sluiced off and 2 to 6 feet (0.6 to 1.8 meters) of gravel was thawed using steam points. The lowest 1.5 feet $(0.45$ meter) of gravel resting on bedrock was then scraped into sluice boxes and washed for gold. Using this method, approximately 200 to 250 cubic yards (153 to 191 cubic meters) of gravel could be washed per day using one cord of wood for fuel (Naske, 1977). The Squaw Creek Mining Company mined on the gulch in 1951 (Naske, 1977). Mining has been sporadic during the last 40 years. There was one operation on Squaw Gulch about 1.2 miles (2 kilometers) above the mouth of the gulch in 1990, and in 1991 another operation was started just above the mouth of Baby Creek.

Squaw Gulch flows entirely within quartzite, schist, and marble of the gneiss, schist, amphibolite, and marble unit (pl. 1), and although Baby Creek flows across a large outcrop of Tertiary sedimentary rocks, these rocks, except for some conglomerates, are not sufficiently resistant to survive much stream travel. A pebble count in Baby Creek (table 1, No. 25) reveals the following rock types: 26 percent quartzite, 22 percent gneiss, 18 percent schist, 14 percent conglomerate, 14 percent granitic rock, and 6 percent quartz. A pebble count in Squaw Gulch is similar (No. 26): 38 percent quartzite, 30 percent schist, 16 percent gneiss, 10 percent granitic rock, 4 percent con- 
glomerate, and 2 percent quartz. The presence of granitic rock in both of these pebble counts implies the existence of small granitic dikes too small to show at the scale of the map.

The gravel in Squaw Gulch and Baby Creek is subrounded to subangular with some boulders of well-rounded quartz as much as 1.6 feet ( 0.5 meters) across. Generally 3 to 10 feet ( 1 to 3 meters) of gravel is present on a fractured, somewhat weathered, clay-rich bedrock. Clay-rich false bedrock horizons on Squaw Gulch sometimes contain gold.

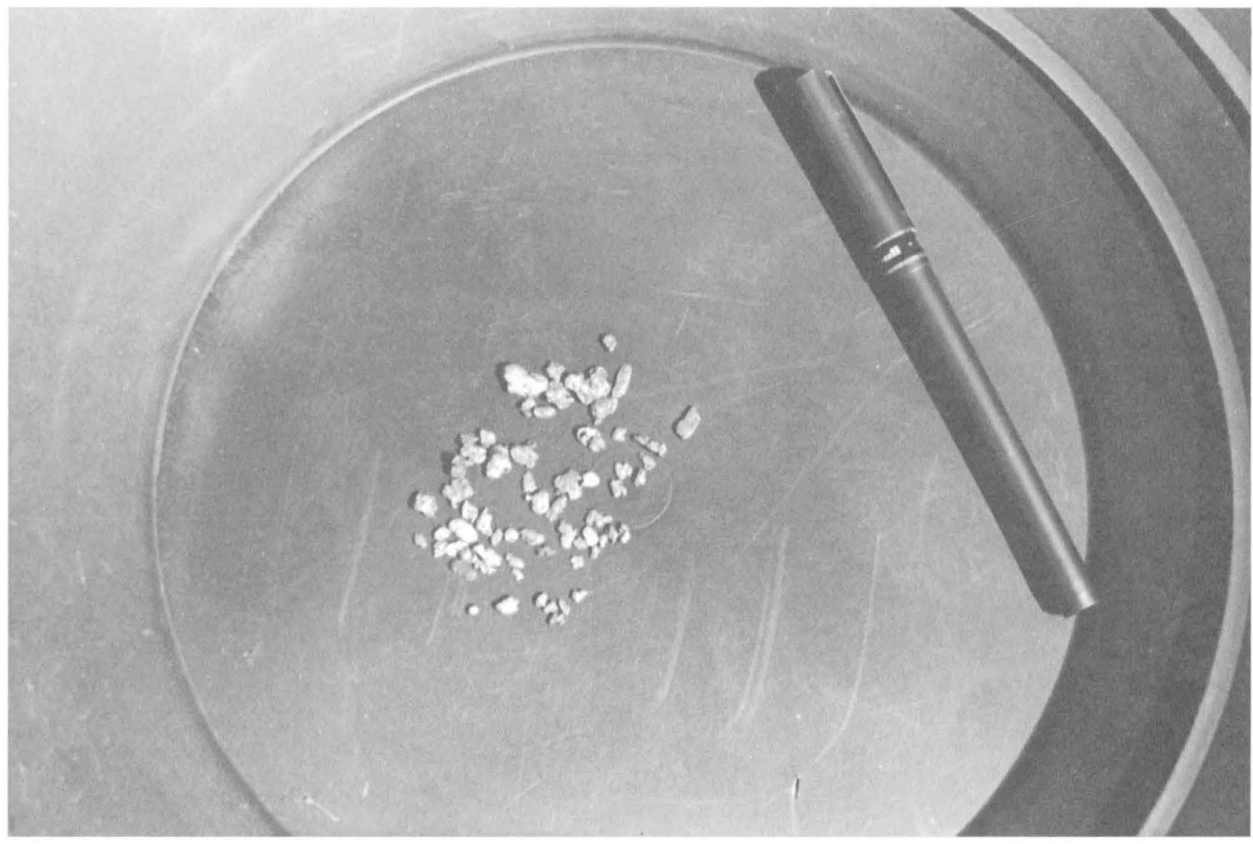

Values of $\$ 4$ per cubic yard (\$3.06 per cubic meter) are reported on Baby Creek from mining in 1991, and most of these values were obtained from the lowest 1.6 feet ( 0.5 meter) of gravel. Flattened gold fragments as much as 2.5 inches ( 1 centimeter) across have been recovered here in the recent mining (fig. 35). Nuggets weighing as much as 2 ounces have been found in the early mining on Squaw Gulch (Prindle, 1905).

Most of the gravel in Squaw Gulch has been mined at least once. Contemporary miners seek isolated pockets of gold-rich gravel that might have been missed, and (or) gold in previously mined gravel that was not recovered because of inefficient mining methods.

\section{Stonehouse Creek}

Stonehouse Creek is the 3-mile-long (5 kilometers) western headwater tributary of Chicken Creek. It was named by prospectors in 1898, probably for the outcrop of rocks at the head of the creek that resemble a house (Haynes, 1976; Orth, 1967). Mertie (1938) described the creek as having a deeply incised, narrow valley with a steep west wall (fig. 36). The floodplain is about 165 to 330 feet (50 to 100 meters) wide. Mining commenced at least as early as 1900 on the creek (Haynes, 1976) and has continued sporadically since. Prindle (1905) stated that a "few men" were working on the creek in 1903. Creek and bench gravels were being mined in 1928 by opencut shoveling-in method (Mertie, 1930). Mertie (1938) mentioned that small-scale mining had been done on Stonehouse Creek for many years, however, there was no mining going on in 1936, when he visited. There was no evidence of any recent mining during my visit in 1991 or 1992.

The upper half of Stonehouse Creek flows within the igneous rock unit where as the lower part of the creek flows within quartzite and schist of the gneiss, schist, amphibolite, and marble unit and Tertiary(?) basalt unit (pl. 1). Numerous small quartz veins cut these
Figure 35 COARSE GOLD RECOVERED FROM BABY CREEK, east-central, Alaska The largest fragment is approximately 0.25 inch (1 centimeter) across, the others, 0.07 to 0.1 inch ( 2 to 5 millimeters). This gold is washed from the lowest 1.6 feet ( 0.5 meter) of gravel lying on bedrock. 
Figure 36 VIEW NORTHWEST TOWARD UPPER PART OF STONEHOUSE CREEK, east-central Alaska. The creek bed appears to be heavily vegetated, and it is doubtful that this part of the creek has ever been mined.

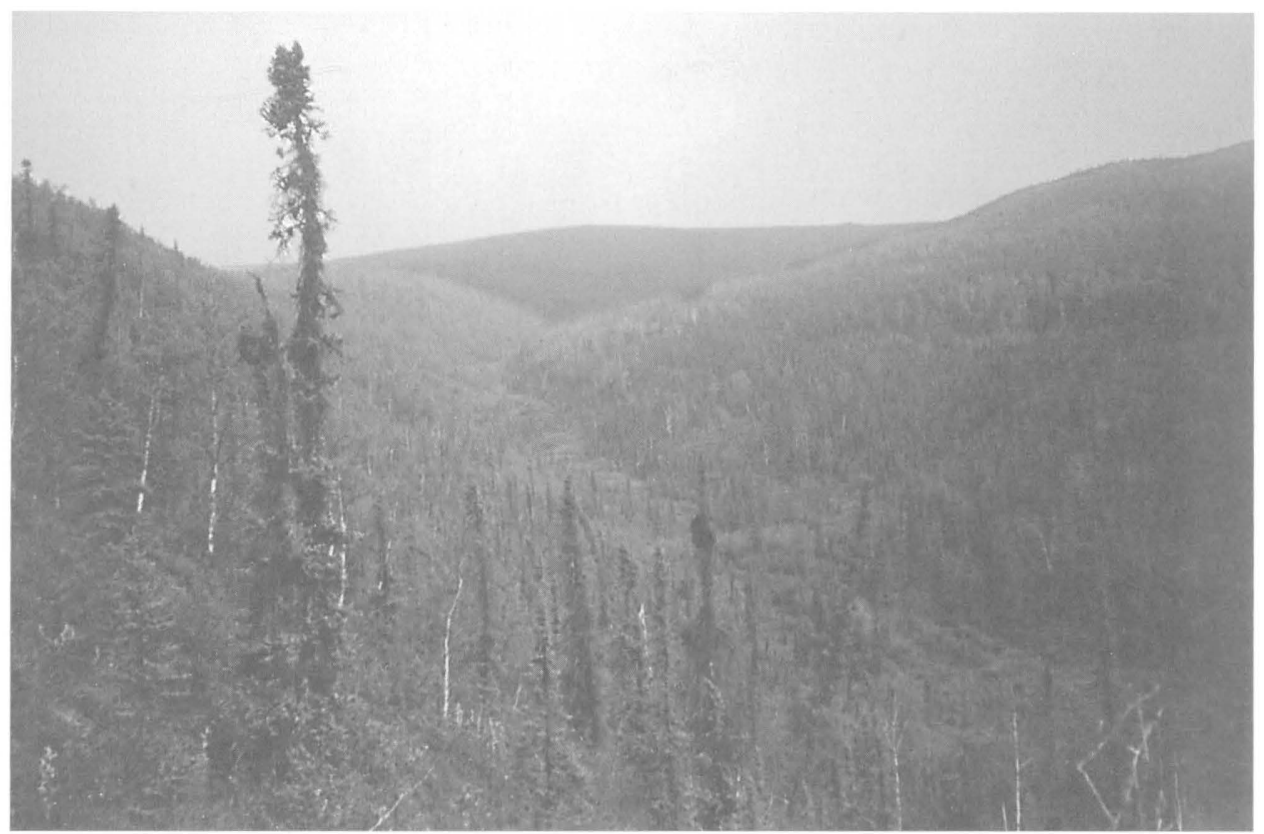

bedrock units. Gold has been found in bedrock in dark schists about 1 mile (1.6 kilometers) north of the junction of Stonehouse and Chicken Creeks. The schist is in contact with quartz diorite porphyry and contains many thin calcite and quartz veins. The quartz veins contain pyrite and the thinner calcite veins contain granular pieces and thin plates of gold (Prindle, 1909). Pebble counts within Stonehouse Creek (pl. 1, No. 27) and on the bench to the north (pl. 1, No. 2; table 1) are quite similar, however, no basalt was noted. The pebble count within Stonehouse Creek reveals a high percentage of granitic rocks: 64 percent granitic rocks, 34 percent greenschist, and 2 percent quartz.

Early mining on the creek revealed about 14 feet (4.6 meters) of gravel on bedrock with the "pay" contained in the lower 3 to 4 feet ( 0.9 to 1.2 meters) (Prindle, 1905). Mertie (1930) described a thin (3.3 feet or 1 meter) veneer of bench gravel 400 feet (122 meters) above the creek on the east side, which contained values of \$36 per cubic yard (\$27 per cubic meter). Remnants of bench gravel exist 70 feet (21 meters) above the creek on the north (pl. 1). Most of this gravel has been mined and the tailing piles, although partially revegetated, show as light-colored areas when viewed from a distance. The bench gravel is 2 to 8 feet ( 0.6 to 2.4 meters) thick, contains mostly subangular clasts and includes boulders, some as much as 1 meter across. Prindle (1905) described the gold recovered from this bench as "rough and dark colored," and he postulated that it may have been derived from locally occurring shales. Unmined gravel seems to be evident in the upper reaches of Stonehouse Creek (fig. 36), however, values are probably uneconomic at current gold prices.

\section{MYers Fork}

Myers Fork, a southeast-flowing tributary of Chicken Creek was named by prospectors and reported by Spurr (1898) in 1896. The earliest mining was probably by underground drifting along the northeast side of the creek and extended upstream from the mouth of the creek for 1,000 feet (304 meters) (Mertie, 1938). Three claims were being worked on the upper part of Myers Fork in 1903 (Prindle, 1905). Two hydraulic plants were in operation on benches of Myers Fork in 1928 and also in 1936 (Mertie, 1930; 1938). Four cuts 20 by 100 feet ( 6 by 30 meters) were made and the gold-bearing gravel mined using water obtained via a ditch from Chicken Creek above the mouth of Stonehouse Creek. The water was used to supply a 2-inch (5-centimeter) giant with a head of 70 feet (21 meters). The 
gravel yielded gold with a value of $\$ 20$ per cubic yard (\$15 per cubic meter) (Mertie, 1930). Mining from opencuts has continued sporadically both within the creek and on adjacent benches (Naske, 1977).

The lower, mined part of Myers Fork is within deeply weathered Tertiary(?) basalt, whereas the upper part of the creek drains terrain underlain by granite, gabbro, quartzite, and schist (pl. 1). A pebble count approximately .6 mile (1 kilometer) up Myers Fork reveals a high percentage of the plutonic rocks, which should be expected because they are certainly the most durable in the drainage (pl. 1, No. 28): 76 percent plutonic rocks, 9 percent quartzite, 13 percent schist, and 2 percent quartz. The high terrace gravels between Myers Fork and Stonehouse Creek contain similar rock types, but they include more metamorphic rocks (pl. 1, No. 29): 57 percent plutonic rocks, 39 percent schist, and 4 percent quartzite.

Gold-bearing gravel in the Myers Fork valley is present in the valley bottom and on a series of adjacent benches. Mertie (1938) described four well-defined bedrock terraces separated by rises of 6 to 8 feet (1.8 to 2.4 meters) along the northeast side of Myers Fork. Three of these surfaces had been exposed by mining at the time of Mertie's visit in 1936. They slope gently toward the creek and have widths of 125 to 150 feet (38 to 46 meters). The fourth surface is about 10 feet ( 3 meters) higher than the third surface and is 40 feet ( 12 meters) above the creek. No physiographic expression of these terraces was apparent prior to mining. A fifth bench is present on the southwest side of Myers Fork 80 feet ( 24 meters) above the creek. Gravel on the benches prior to mining ranged from 3 to 25 feet ( 0.9 to 7.6 meters) thick overlain by as much as 11 feet (3.3 meters) of muck and silt (Mertie, 1938). The gravel consists of subrounded to subangular clasts and includes rare boulders as much as 1.6 feet ( 0.5 meters) diameter. Much of the gravel is fine grained, called "chicken feed" by Mertie, and contains abundant sand beds (fig. 37 ).

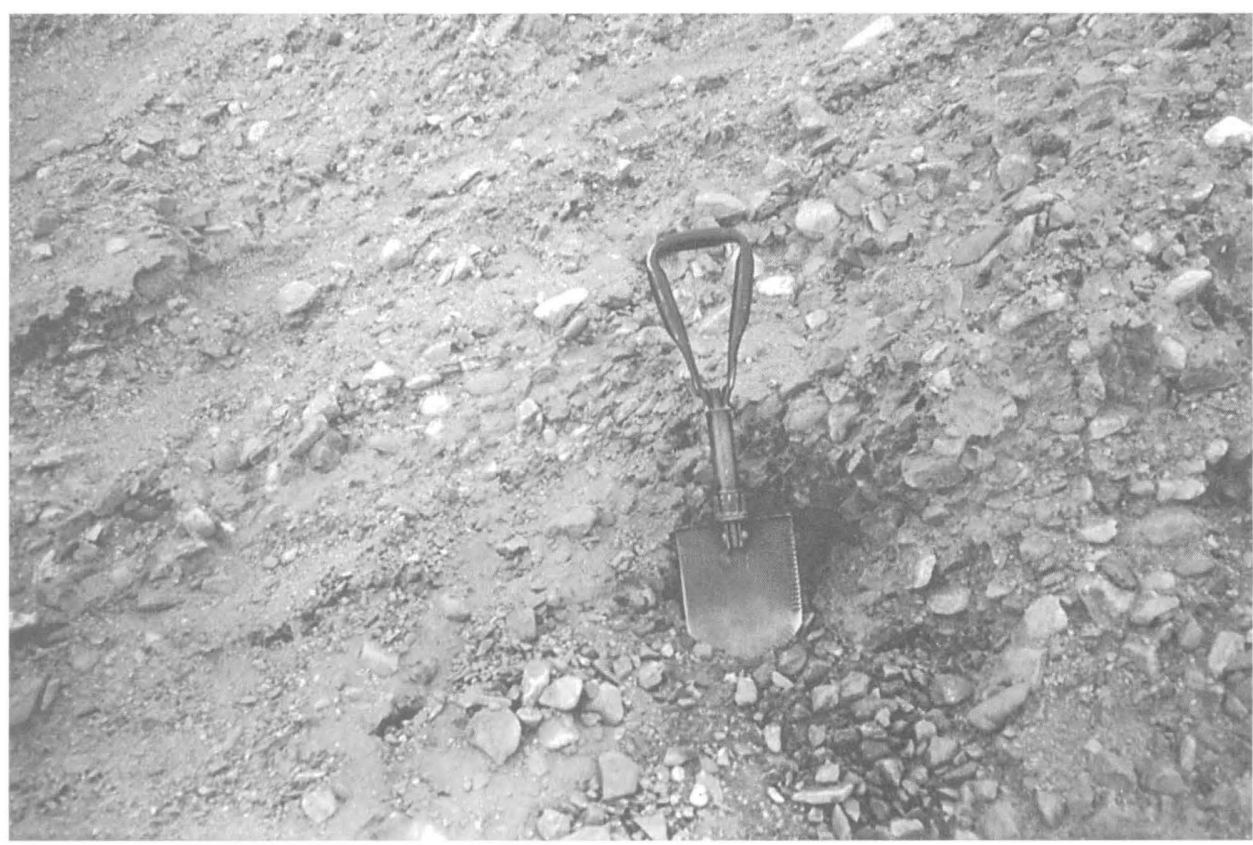

Gold recovered in the Myers Fork drainage is generally composed of fine-grained fragments. One nugget of 1.5 ounces was found (Mertie, 1938). Coarse gold fragments recovered in recent mining are commonly 0.07 to 0.15 inches ( 2 to 4 millimeters in diameter) and a few are as much as 0.3 inches ( 9 millimeters). The gold is both yellow and brown in color. Fineness averages 833 (Mertie, 1938), which is similar to that found in Chicken Creek (835).
Figure 37 BEDDED GRAVEL exposed on terrace 80 feet (24 meters) above Myers Fork (east-central Alaska) on southwest side. 
Figure 38 AERIAL VIEW WEST TOWARD JUNCTION OF INGLE CREEK AND MOSQUITO FORK OF FORTYMILE RIVER, east-central Alaska. Recent mining has occurred near mouth of Ingle Creek and across Mosquito Fork, where water ponds are evident.
The gravel in the lower 1.2 miles (2 kilometers) of Myers Fork has been repeatedly mined and mining continues here. Some of the gravels in the upper part of Myers Fork seem to be unmined, as is some of the high level terrace gravel capping the divides both north and south of the Myers Fork valley (pl. 1), however values are generally low here.

\section{INGLE AND LiLliWig CREeKS}

Ingle Creek is a short (4 miles or 6.4 kilometers) drainage emptying into Mosquito Fork about 3.7 miles (6 kilometers) above the confluence of Mosquito and Dennison Forks (fig. 38). The creek was named for and staked by a man named Jake Ingle in the late 1890's and is considered one of the oldest producing creeks in the district. Except for near the mouth, the valley of Ingle Creek is narrow with steep side slopes, and there is little gravel in its narrow floodplain (fig. 39). Early mining on Ingle and its principal tributary, Lilliwig Creek, was done by shoveling-in to elevated sluice boxes and using water derived from small upstream dams along the creeks. In 1909 Ingle and Lilliwig Creeks were being mined by drifting and opencut work (Brooks, 1910). During the winter of 1912-13, frozen gravel was thawed using steam, and the gravel was stockpiled for washing in the summer months. In 1920 ground near the mouth of Ingle Creek was being mined using boilers, scrapers, and hoists, all of which eventually proved to be unfavorable methods (Haynes, 1976). Open cut mining on Ingle Creek was in progress during Mertie's (1938) visit in 1936. Sporadic mining has occurred on Ingle Creek to this day; however, the low water volume in the creek limits mining in dry years.

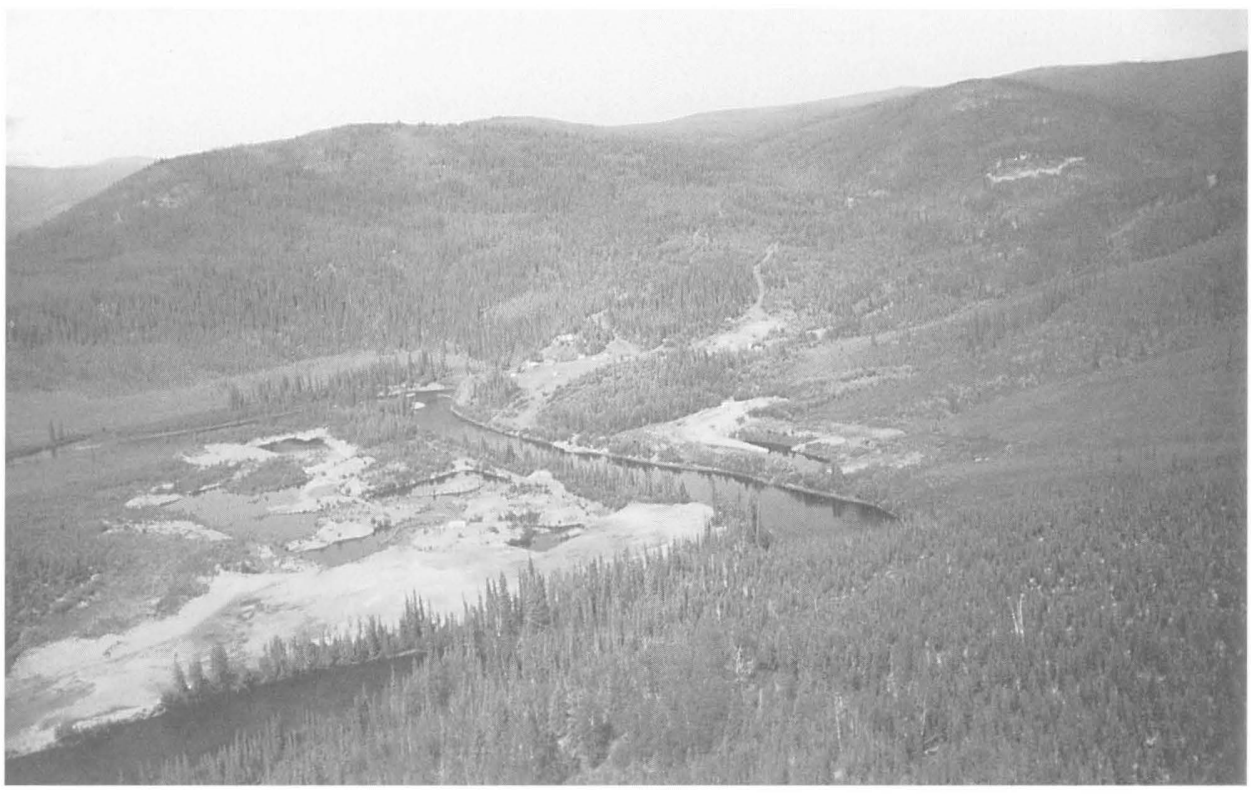

The bedrock is mostly granitic rock but includes some schist and quartzite (pl. 1). Mertie (1930) described a quartz diorite body cropping out on Lilliwig Creek upstream from where "workable placers" were mined. Placers were not present upstream from this intrusion. Mertie described a mineralized zone in this intrusion that was prospected as a gold lode. The lode material consisted of numerous parallel stringers of vein quartz and calcite trending east-west and cut by another system of stringers trending north-south. The rock was "much sericitized" and the sericitized bedrock and vein material contained gold-bearing sulfides, pyrite, and chalcopyrite. One assay of the sulfides indicated 1.87 ounces of gold and 2.05 ounces of silver to the ton (Mertie, 1938). 


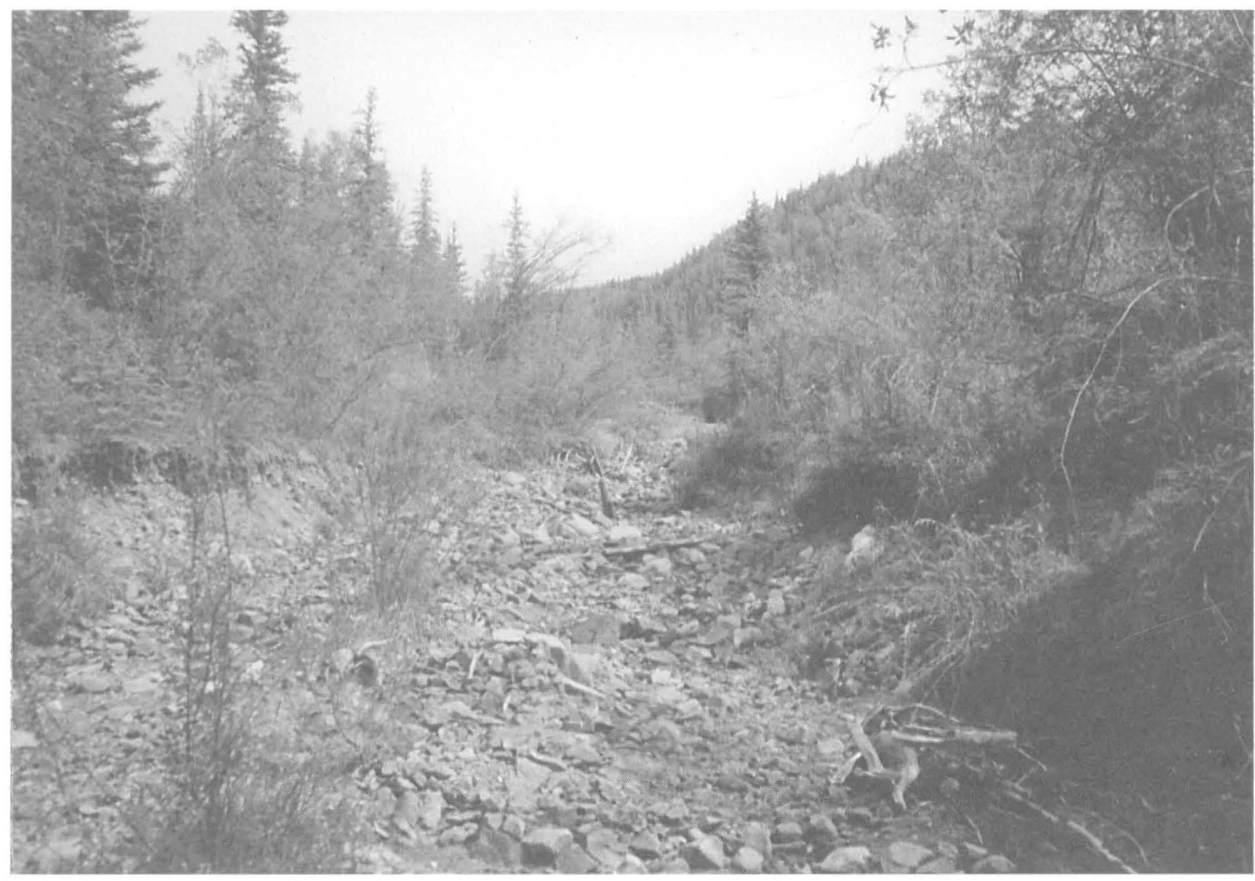

A pebble count from Ingle Creek reveals (pl. 1, No. 30): 50 percent schist, 38 percent granitic rock, 7 percent quartz, and 5 percent quartzite.

The gravel in Ingle Creek consists of angular to subangular cobbles and boulders as much as 2.5 feet ( 0.75 meter) across. Except near the mouth of the creek where the gravel is as much as 23 feet ( 7 meters) thick, there is generally $1 \mathrm{~m}$ or less of gravel on bedrock in the creek bed. The recovered gold is coarse, often 0.11- to 0.2- inch (3- to 5-millimeter) fragments; a 3.5-ounce nugget was recovered by early miners. More recently, nuggets larger than 3/4 ounce have not been recovered. Fineness of gold recovered in 1919, 1924, and 1929 averaged 851 (Mertie, 1938). Little unmined gravel remains on Ingle or Lilliwig Creek, although there may be some very thin, narrow deposits in the upper 1.2 miles (2 kilometers) of Ingle Creek.

\section{OTHer CReeks}

Buckskin, Fortyfive Pup, Uhler, Mosquito Fork, and Alder Creeks have all supported some placer mining, active prospecting, or have gold potential, but there is only meager information available about these creeks.

Buckskin Creek is the tributary emptying into the South Fork of the Fortymile River about 2 miles ( 3 kilometers) north of the mouth of Franklin Creek. A little mining took place on the creek in 1905, 1914, and 1935. The pay streak is reported to be 200 to 300 feet (61-91 meters) wide with 12 to 16 feet (3.6 to 4.9 meters) of overburden (Mertie, 1938). A pebble count in Buckskin Creek just below the mouth of Fortyfive Pup revealed (pl. 1, No. 31): 32 percent quartzite, 26 percent granite, 18 percent schist, 10 percent gneiss, and 14 percent quartz. The high terrace is well developed along the lower 3.7 miles (6 kilometers) of Buckskin Creek. It is 400 feet (122 meters) above the creek level and has a thin 3 to 6.5 feet ( 1 to 2 meters) veneer of gravel and sand. Gold flakes as much as .1 inch ( 3 millimeters) across were panned from the high terrace gravel on the south side of Buckskin Creek. Gold from Buckskin Creek is reported to have a low fineness-620, which is about 25 percent lower than other creeks in the area (Mertie, 1938). There was no mining on the creek during my visit in 1992. The high terrace gravels may have some placer gold potential, however, the expense of mining this gravel that is far removed vertically from water will discourage mining here.
Figure 39 VIEW UP INGLE CREEK showing narrow floodplain and coarse gravel present. Photograph taken about 0.6 mile (1 kilometer) above mouth of creek. 
Figure 40 AERIAL VIEW NORTHWEST UP FORTYFIVE PUP. Mined regions in creek are unvegetated lightcolored areas.

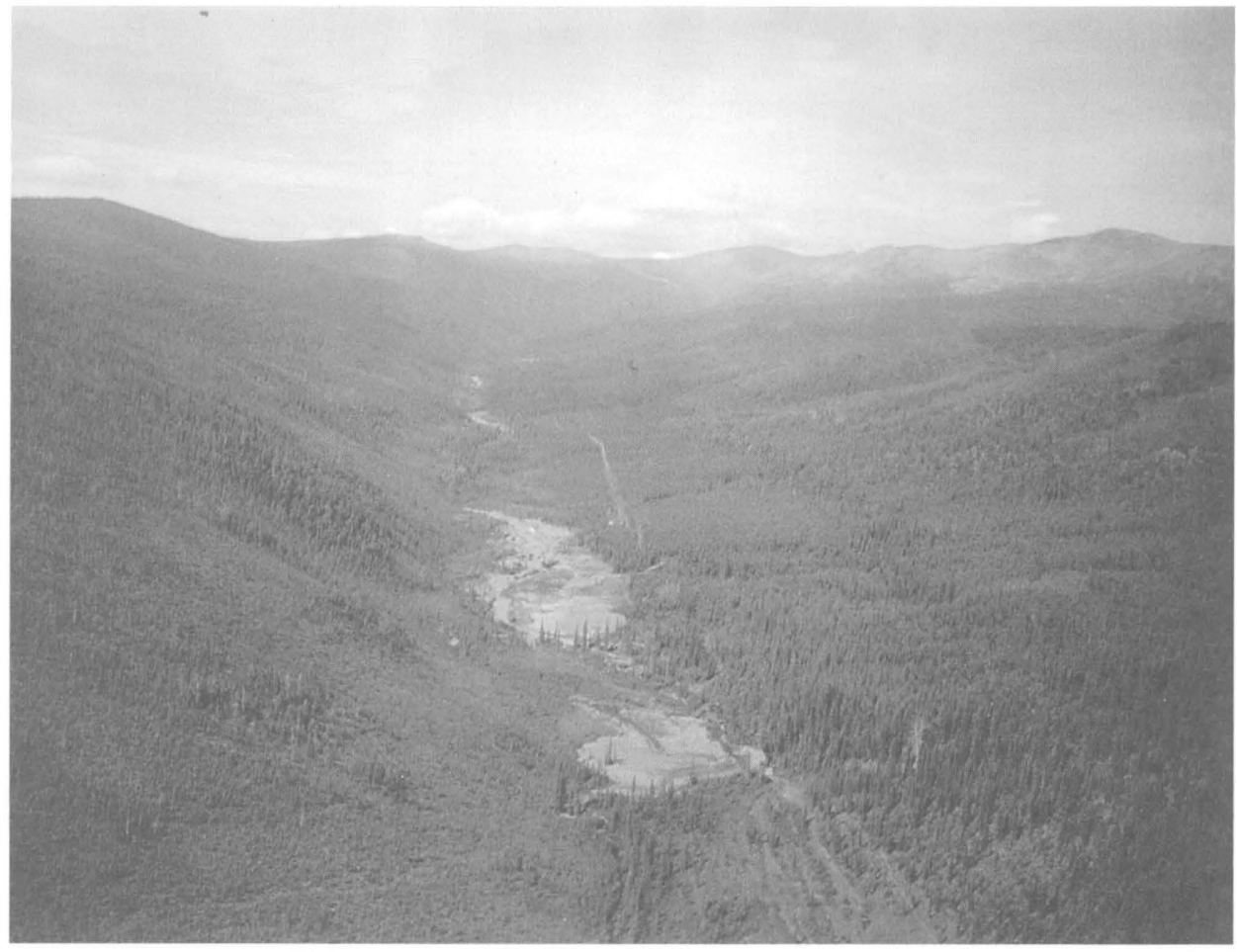

Fortyfive Pup is a 6.2-mile-(10-kilometer) long tributary of Buckskin Creek (fig. 40), Small creeks are often referred to as "pups." The term appears to have originated on Miller Creek in the adjacent Seventymile Mining District (Spurr, 1898). Mining on Fortyfive Pup has been intermittent since 1910, and it has been nearly continuous since the 1960's (Eberlein and others, 1977). A pebble count in the upstream part of Fortyfive Pup revealed a high percentage of schist clasts (pl. 1, No. 32): 52 percent schist, 26 percent granite, 14 percent quartzite, and 8 percent quartz. The fineness of gold here is the same as on Buckskin Creek-620.

Uhler Creek is a remarkably straight west-flowing tributary of the South Fork that empties into the river about 3 miles (5 kilometers) downstream from the mouth of Buckskin Creek (fig. 41). The creek was mined in the early 1900's, and small-scale mining took place during the 1960's and 1970's (Eberlein and others, 1977). Clasts in the creek gravel are subrounded to subangular and mostly about 4 inches (10 centimeters) or less in diameter. A pebble count about halfway up the creek shows (pl. 1, No. 33): 44 percent granite, 24 percent quartzite, 20 percent schist, and 12 percent quartz. No information on gold values or production figures was found.

The Mosquito Fork flows into the South Fork about 1.2 miles (2 kilometers) below the mouth of Chicken Creek. It flows in a broad valley and has been the site of infrequent placer mining. The remains of the Lost Chicken Dredge can be seem today mired in the floodplain gravel of Mosquito Fork about .3 mile ( .5 kilometer) above the junction with South Fork (fig. 21). It is believed that it ended its career dredging the gravel here in the late 1930's. Gravel along the Mosquito Fork has been mined for gold near the mouth of Ingle Creek, and the tailings resulting from this mining have not yet revegetated (fig. 38). A small operation was mining gravel in the floodplain of the Mosquito Fork during the summer of 1992 about .6 mile (1 kilometer) below the Taylor Highway bridge. A pebble count near the highway crossing revealed the following (pl. 1, No. 34): 44 percent granite, 38 percent greenstone, 12 percent quartzite, 2 percent quartz, 2 percent schist, and 2 percent basalt. A panned-concentrate sample here yielded a single gold flake and an abundance of black sand. Because Mosquito Fork is downstream and 


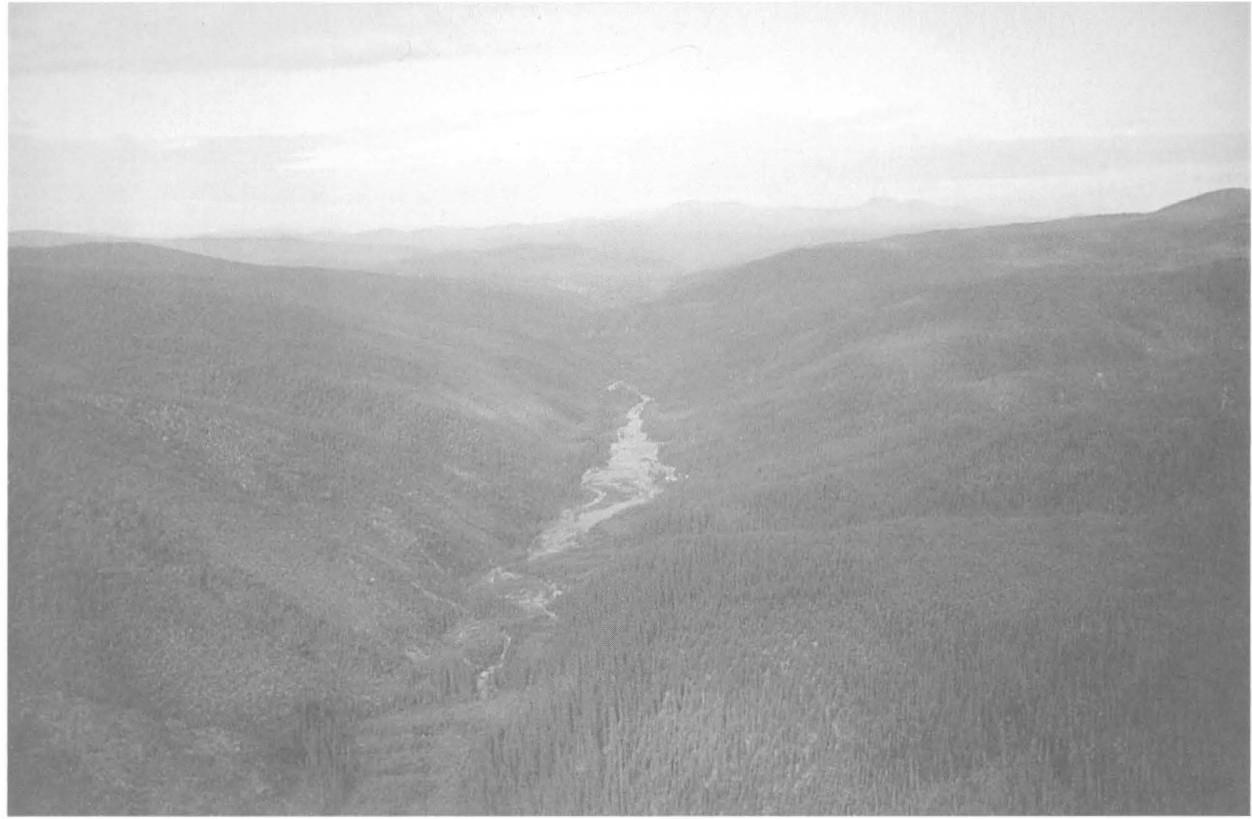

receives gravel from gold-rich Chicken and Ingle Creeks, it is reasonable to assume that placer gold is present in the floodplain gravel of Mosquito Fork. However, because of the large volume of gravel in the broad floodplain of the river, the unit value is probably low. This low unit value probably accounts for the paucity of mining on Mosquito Fork

Alder Creek, a tributary of O'Brien Creek, has no published record of mining, however, it does have some placer gold potential. Remnant terraces capped with 3 to 6.5 feet ( 1 to 2 meters) of coarse gravel are present some 390 to 490 feet (120 to 150 meters) above the creek. More importantly, a geochemical analysis of stream-sediment samples collected from Alder Creek in 1968 (Foster and Clark, 1970) revealed anomalous amounts of silver, zinc, arsenic, chromium, copper, nickel, and lead elements indicative of mineralization that often includes gold. Alder Creek drains an area that consists primarily of metamorphic rocks, and marble is the most abundant rock type exposed along the creek.
Figure 41 AERIAL VIEW TOWARD WEST DOWN UHLER CREEK, east-central Alaska. Mined gravel shown by the unvegetated, light-colored areas. 


\section{Heavy Minerals}

Panned-concentrate samples were collected from most gold-producing creeks and associated high terrace gravels in the Fortymile River region, generally at the same locality at which pebble counts were made (pl. 1). Heavy minerals, in addition to gold, are contained in these panned concentrates. A binocular microscope was used to determine the percentages of heavy minerals in the concentrates. Several observations were made on the basis of this analysis.

1. Almost all panned-concentrate samples contain varying percentages of two minerals. These are magnetite- -20 to 80 percent, and ilmenite -10 to 30 percent.

2. In addition to magnetite and ilmenite, samples from creeks draining areas principally composed of metamorphic rocks contain garnet-10 to 30 percent.

3. Garnet was anomalously high in three areas: Buckskin Creek and the high terrace along Buckskin Creek-40 to 50 percent; Wade Creek-25 to 40 percent; and Cherry CreekTurk Creek -40 percent.

4. Samples from creeks draining areas principally underlain by granitic rock contain large amounts of ilmenite. These creeks are Myers Fork, Chicken Creek, Ingle Creek, Lost Chicken Creek, and upper South Fork. The high terrace gravels of Lost Chicken, Chicken, Napoleon, and Dome Creeks, Myers, and Mosquito Forks all contain higher percentages of ilmenite than the present floodplain creek gravel; this difference implies more widespread occurrence of granitic rocks during times of high terrace development (late Tertiary and early Pleistocene) than at present.

5. Samples from Twelvemile and Stonehouse Creeks contain anomalous amounts of pyrite- 70 to 80 percent. Such high concentrations of pyrite imply localized mineralization took place in these areas.

6. Barite in anomalous amounts is present in a few of the heavy-concentrate samples from Wade Creek.

7. Zircon, epidote, amphibole, tourmaline, apatite, and pyrite are commonly present in these samples, but they are present at values of less than 5 percent. Rarely present in these samples are the minerals pyroxene, diopside, olivine, kyanite, hematite, limonite, sphene, scheelite, cinnabar, and cassiterite. 


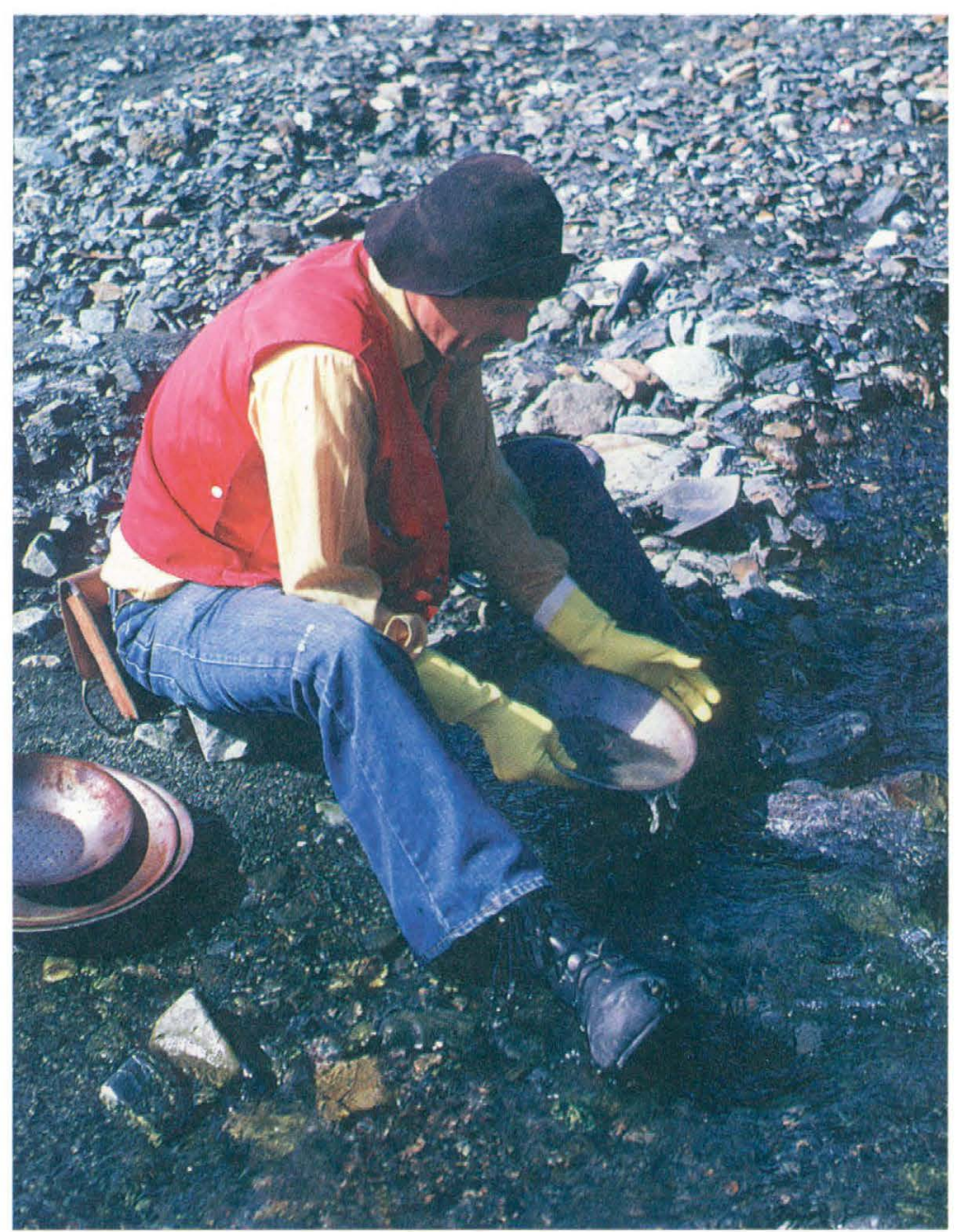

The author panning for samples in the Fortymile River Region, Alaska. 


\section{GOLD OCCURRENCE}

Examining where gold is present relative to bedrock in the vertical section, relative to channel borders in the horizontal section, and relative to downstream distance from the source in the longitudinal section is useful for comparing patterns of distribution between drainages and for determining source areas and origins. Such studies also help determine size, shape, and trace-element content of the gold.

Most placer gold in the Fortymile River area, as in most placer districts, is recovered at or near the gravel-bedrock contact. The lowermost 3.3 feet ( 1 meter) of gravel and the uppermost 1.6 feet ( 0.5 meter) of bedrock may contain as much as 80 to 90 percent of the gold ultimately recovered. An explanation for the concentration of gold in the lower part of river gravel presented for the ancestral Yuba River in California (Yeend, 1974) seems plausible for creeks in the Fortymile River area. Gold, because it is much heavier than the associated sedimentary silicate particles, works its way down to the lowest horizon of unconsolidated detritus during water transport. The gold remains stationary and is covered by gravel during much of the time it is in this alluvial environment. Only during turbulent water flow, such as that associated with floods, will the full thickness of the creek gravel be put in suspension and moved along the creekbed. Whereas most constituents of gravel are undergoing transport downstream during floods and high runoff, gold lags behind, much as it does in a sluicebox. As more and more gold-rich detritus is brought into the drainage, all but the gold is broken down to smaller and smaller particles and flushed downstream, and it eventually ends up in a marine or lacustrine environment. The gold, however, stays in the alluvial environment and increases in concentration through time as more and more is carried into the creek. Some of the very finest flour gold may be transported out of the river system, but most gold stays in the creekbed. During each succeeding flood, the gold continues its downward migration through the sediment; consequently, most placer gold is found on or near bedrock in the streambed.

Within an alluvial environment, areas of slight decreases in stream gradient, and consequently lower water velocity, are sites of gold deposition. The insides of meanders, plunge pools at the downstream ends of rapids and riffles, and the downvalley sides of large boulders are good places to search for gold because these areas are sites of slowing water velocity, a process which results in the deposition of contained sediment. Trying to find such sites in the stratigraphic section that record a stream's history is a challenge to the miner. A resistant bedrock unit crossing a stream such as a tough dike, a major contact of hard against soft bedrock, or a fault cutting across a drainage often produces a change in stream gradient, and such places may become sites of gold deposition.

Metz (1987) determined during work in the Fairbanks District that the upper limit at which a placer deposit would form is a gradient of 440 feet per mile ( 83 meters per kilometer) consequently, parts of creeks with gradients steeper than this would not contain rich gold placer deposits, although they might possess some gold. In the Fortymile River area there are no 
known creeks where mining has occurred at locations of gradients greater than 440 feet per mile (83 meters per kilometer). Equally important is that economic concentrations of gold will not always be found all the way up a valley to regions where creek gradients are this steep. Only two creeks, Lost Chicken and Lilliwig, have gradients approaching 300 feet per mile (57 meters per kilometer) where placer gold has been mined. Most of the mining in the Fortymile River area has been in areas where the creek gradients are below 200 feet per mile (38 meters per kilometer).

Gold is also concentrated laterally and longitudinally along a stream valley in irregular patterns governed primarily by gradient. There may be several paystreaks vertically in the gravel section and also laterally across and longitudinally up- and downvalley in a creek. Paystreaks within creeks of the Fortymile River area are generally several tens of meters wide in valleys having a minimum width of 328 feet (100 meters). A paystreak is often several hundreds of feet in length. Water velocity in the stream valley, besides being governed by streambed gradient, is also dependent on discharge. During floods, velocities increase and most erosion, transport, and reworking of detritus occurs. Climate is a factor affecting the amount of water in a drainage, and as climates change differing amounts of rock and gold will be eroded, transported, and finally concentrated. With so many factors affecting the final location and richness of a paystreak, the difficulty of accurately predicting their locations within placer gravels becomes apparent.

Gold nuggets in the Fortymile area are rare. Most gold recovered is in the form of flattened fragments less than .2 inch ( 5 millimeters) in greatest dimension. The gold particles have round, often curled edges, and a few have abrasion scratches on their lustrous surfaces. Some grains are not flattened and are often compared to wheat grains and match heads in shape. A few ragged, uneroded gold fragments have also been recovered. Such flakes do not necessarily imply a nearby bedrock source; rather, they most likely spent most of their erosional history as part of a cobble or boulder of quartz or schist and retained their raggedness after subsequent separation from the clast because of little transport. A variety of nugget shapes have been recovered, although most of the nuggets found generally have rounded edges (fig. 35).

Gold flakes are almost always shiny and are easy to identify in a gold pan with other heavy minerals present. A few gold grains have been recovered that have a dull luster because of thin coatings of iron and manganese oxide and quartz. Much gold found in the Fortymile District has adhering minerals such as quartz, magnetite, and ilmenite. Most quartz adhering to gold grains is partially crystalline.

\section{GOLD FINENESS}

The purity of gold from different areas, even in the same district, is variable. A measure of this purity is gold fineness. Even though the significance of fineness values in interpreting the genesis or history of a deposit is not always evident, fineness values can give some idea of similarity or dissimilarity of the gold from different areas. As used herein, fineness, often called true fineness, is defined as the ratio of gold to gold plus silver, times $1,000(\mathrm{Au} /(\mathrm{Au}+\mathrm{Ag}) \times$ 1,000) (Boyle, 1979, p. 197). True fineness values of placer gold from 22 creeks in the Fortymile River area are shown below. These data are taken from the report by Metz and Hawkins (1981) and vary somewhat from those reported in the individual creek writeups denoted elsewhere in this report, data which were taken from the earlier report of Mertie (1938). Metz and Hawkins concluded that individual mining districts within Alaska cannot be distinguished by fineness alone. Sources may be from different host rock types, such as quartz veins associated with intrusive rocks, or massive sulfide deposits associated with metamorphic rocks. Varying temperature of formation in the same geologic environment could also produce different fineness values. Also, weathering and diagenetic changes occurring during the erosion, transportation, and deposition of gold particles could cause changes in the gold-silver ratios (Forbes, 1980). Consequently, it is difficult to attribute a valid meaning to the fineness data.

\begin{tabular}{|c|c|}
\hline Creek & Fineness* \\
\hline Canyon & 791 \\
\hline Chicken & 833 \\
\hline Davis & 885 \\
\hline Dome & 907 \\
\hline Fortymile & 876 \\
\hline Fortyfive Pup & 916 \\
\hline Franklin & 883 \\
\hline Ingle & 902 \\
\hline Lost Chicken & 927 \\
\hline Mosquito Fork & 871 \\
\hline Myers Fork & 857 \\
\hline Napoleon & 876 \\
\hline N. Fk. Fortymile & 871 \\
\hline Poker & 864 \\
\hline Smith & 836 \\
\hline S. Fk. Fortymile & 869 \\
\hline Squaw & 886 \\
\hline Stonehouse & 821 \\
\hline Turk & 815 \\
\hline Uhler & 858 \\
\hline Wade & 862 \\
\hline Walker Fork & 883 \\
\hline${ }^{*}(\mathrm{Au} / \mathrm{Au}+\mathrm{Ag})$ & $=1,000$ \\
\hline
\end{tabular}




\section{GolD SOURCE AND RESOURCE}

A lode source for the placer gold in the Fortymile River area has eluded both prospectors and geologists. The placers are recovered from creeks whose drainage basins are within sparsely mineralized quartzite, schist, marble, and granitic rock. Although it seems that much of the gold in the present stream flood plain deposits has been recycled through the high terrace gravels, the ultimate bedrock gold source is not readily apparent. Bedrock with gold is seldom found in the Fortymile River area and is even more rarely found directly associated with placer deposits here. Early reports attempted to relate the placers to the schist bedrock. Spurr (1898) reported the occurrence of a gold-rich quartz vein in a block of quartz schist, and he concluded on the basis of similar rocks in the Circle, Fortymile, and Klondike Districts that the quartz veins and quartz schists were the source of the gold. The gold source for the placers in the Fortymile River area may be small mineralized quartz veins in metamorphic rocks. Mertie (1938) described such quartz veins along Wade Creek and proposed that the gold-rich veins were associated with concealed granite. Sheared mineralized diorite and quartz diorite, quartz-calcite veins, and calcite veinlets cutting greenschist-facies metamorphic rocks and sheared granitic rocks in the Lost Chicken Creek area contain gold (Foster and O'Leary, 1982). Gold is also present in crushed, faulted zones in the Dome and Canyon Creeks area (Foster and others, 1987). Prindle (1909) reported the presence of lode gold at four localities within the Fortymile River area. These four localities are (1) a brecciated zone of quartz diorite along the Mosquito Fork about 4 miles (6 kilometers) west of the mouth of Lost Chicken Creek, (2) thin calcite seams in black phyllite very close to quartz diorite near the head of Chicken Creek, (3) brecciated vein quartz in quartzite schist within a zone of intrusions near the head of Kalamazoo Creek (labeled Kal Creek on figure opposite and pl. 1), and (4) quartz veins on Davis Creek. Mertie (1930) described gold-bearing sulfides associated with calcite and veinlets of quartz in a sericitized quartz diorite at the head of Lilliwig Creek, a sample of which assayed at 1.87 ounces of gold per ton ( 58 grams per metric ton). The only lode gold mine in the area (Purdy Quartz Mine) consists of a rich vein and veinlets of gold, calcite, and quartz on the ridge northeast of Myers Fork (fig. 29). The bedrock is meta-siltstone, phyllite, and quartzite. Gold was mined here to a depth of 6.5 feet ( 2 meters), where the vein abruptly ended (Foster, 1969). Although the area was extensively prospected the continuation of the vein was not found.

Most of the placer gold found in the Fortymile Mining District has come from the southeast quarter of the Eagle quadrangle. Geologic maps of the Eagle quadrangle (Foster, 1976) and of the eastern Yukon-Tanana region (Foster, 1992) clearly show the prevalence and almost unique occurrence of one geologic unit mapped in this area. Termed the Y4 subterrane of the Yukon-Tanana terrane (Foster and others, 1987) and the Taylor 


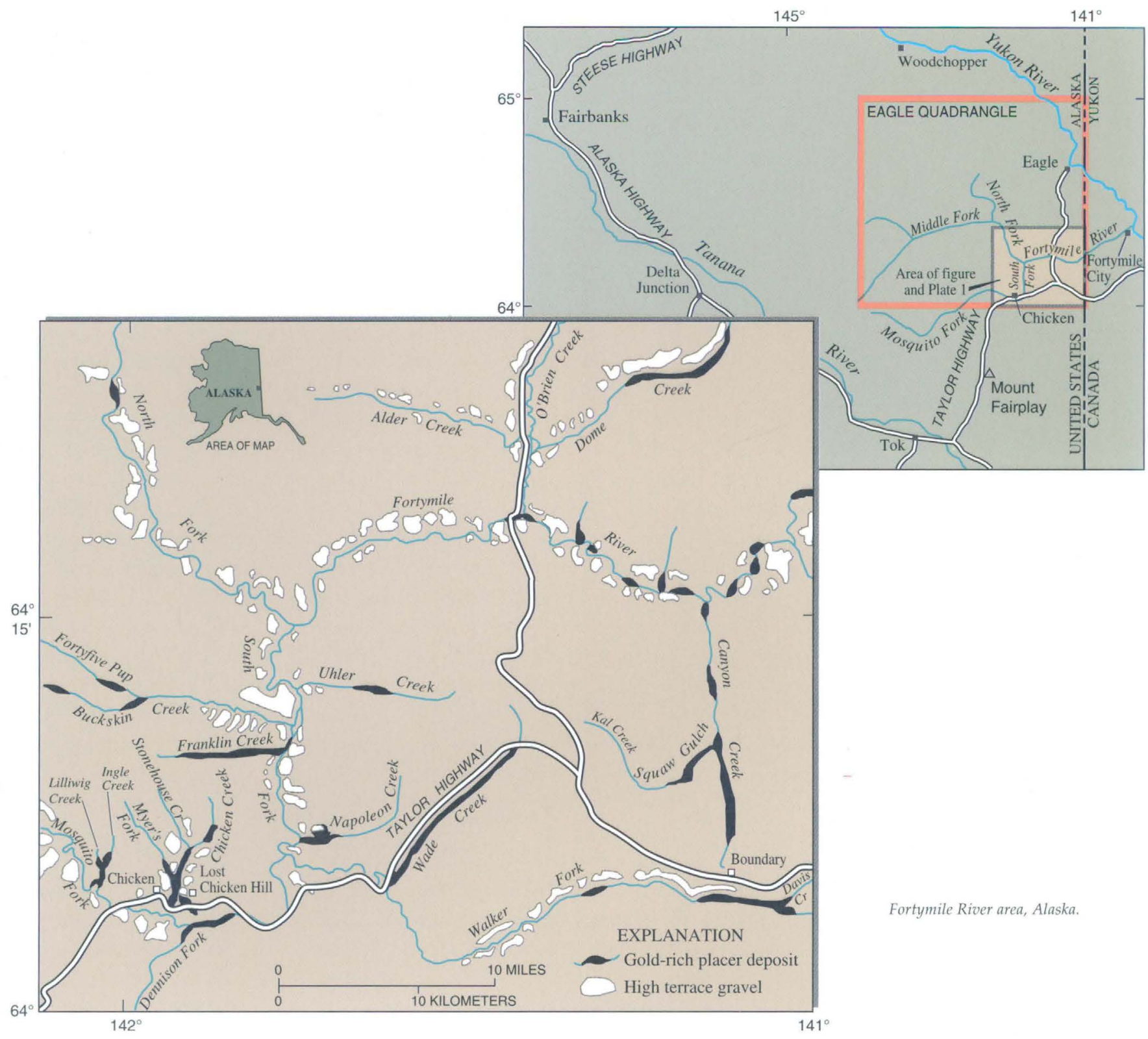

Mountain terrane or subterrane of Dusel-Bacon and Hansen (1992, 1991), it is readily identified on the geologic map of east-central Alaska (fig. 1 of Foster and others, 1987) by being almost completely encircled by thrust faults. Herein, this it is called the gneiss, schist, amphibolite, and marble unit (pl. 1). The spatial association of this mapped unit with the occurrence of placer gold-rich creeks and rivers seems too precise to be attributed to chance. Therefore, I propose that the presence of this unit in the Fortymile River area is somehow linked to the occurrence of lode gold in the area. One theory is that this unit includes rock types containing gold that eventually, through remobilization, became concentrated in quartz veins. Another theory is that this unit provided a structural environment conducive to emplacement of gold-rich plutonic rocks, which gave rise to gold-rich quartz veins. Erosion of the gold from the quartz veins led to the formation of placer gold deposits in the high terrace gravels. As these terraces were subsequently eroded, gold was reconcentrated in the floodplain gravels of the creeks and rivers.

The Circle District in Alaska is 124 miles (200 kilometers) to the northwest and is similar to the Fortymile River area in having no identified rich lode source for the gold 
found in placers there (Yeend, 1991). Prindle (1905) thought that the gold found on creeks in the Circle District had been derived from large areas of bedrock almost uniformly mineralized and that there were probably no zones or pockets especially rich in the metal. McConnell (1905) studying the gold placers in the Klondike suggested that the original gold content of the quartz was probably no more than a few cents to the ton and hence the veins might not be productive even if discovered. Similar conclusions were reached by Loen (1992) in studying mass-balance constraints on gold placers of varying ages and in a variety of locations such as Fairbanks, Alaska (Pliocene to Quaternary), Sierra Nevada, California (Eocene to Quaternary), and Witwatersrand, South Africa (Archean). Several of Loen's conclusions are presented herein because they might have bearing on the Fortymile River area placers for which no lode source has been identified. (1) Cenozoic gold placers develop from the gradual erosion of large volumes 10 to 10,000 cubic kilometers of source rocks that contain essentially background mean gold contents, (2) no correlation exists between mean source-rock gold content and amount of gold in placers, indicating that other factors (such as degree of weathering of source rocks, volume of rock eroded, and efficiency of concentration processes) are of greater importance than the richness of source regions, and (3) the concentration of gold in placers is inefficient because of incomplete release of gold from source rocks and transport of gold out of the system in solution, suspension, and chemical complexes. An estimated 50 to 90 percent of the gold that was present in source rocks cannot be recovered from placers. If these conclusions are valid, it might be unproductive to search for the "mother lode" within the bedrock of the Fortymile area. It is an instructive and interesting exercise to calculate what might be the expected amount of placer gold deposited in the Fortymile River area using Loen's (1992) mass-balance equation and making some assumptions on the efficiency of the gold release system, erosion rates, and duration of erosion. The mass-balance equation.(Loen, 1992) is:

$$
\mathrm{P}=\frac{\left(\mathrm{D} \times \mathrm{A}_{\mathrm{d}} \times \mathrm{C} \times \mathrm{T} \times \mathrm{R}\right)}{100} \times \mathrm{E}
$$

where $\mathrm{P}=$ total mass of gold in the placer deposit (tons $\mathrm{Au}$ ), $\mathrm{D}=$ mean density of the source rocks $\left(t / \mathrm{m}^{3}\right.$ or tons per cubic meter $), A_{d}=$ drainage basin area $\left(\mathrm{km}^{2}\right.$ or square kilometers), $\mathrm{C}=$ mean abundance of gold in source rock (ppb or parts per billion), $\mathrm{R}=$ mean denudation rate $(\mathrm{cm} / \mathrm{ka}$ or centimeters per thousand years), $\mathrm{T}=$ time constraint on erosion of source rocks (My or millions of years), and $\mathrm{E}=$ efficiency of weathering and concentration processes (in percent). Efficiencies of placer-forming systems would be expected to be low because a substantial portion of the heavy minerals are either not released by weathering or are chemically and mechanically lost from the system (Loen, 1992). Solving for $P, D$ is $2.65 \mathrm{t} / \mathrm{m} 3$, the mean density of rocks; $A_{d}=2,000 \mathrm{~km}^{2}$, the approximate area of the gneiss, schist, amphibolite, and marble unit (pl. 1), which is the suspected gold source, in the Fortymile River area. The mean abundance of gold in the source rock (C) is $6.5 \mathrm{ppb}$, the average gold content of 560 samples of greenschist and amphibolite (Crocket, 1991). This amount of trace gold could not be recovered or even concentrated in the placers; rather, this gold must have been hydrothermally concentrated into "particulate" gold in epigenetic deposits, such as quartz veins, prior to erosion and eventual concentration as placers (Henley and Adams, 1979). Time available to erode the source rocks of and deposit the gold-bearing gravel deposits (T) in the Fortymile River area is $5 \mathrm{~m} . \mathrm{y}$. The denudation rate $(\mathrm{R})$ is $30 \mathrm{~cm} / \mathrm{ka}$, a relatively high rate resulting from the periglacial processes (Péwé, 1975) in the unglaciated part of central Alaska. The efficiency of weathering and concentration (E) is 10 percent, which is perhaps the least understood variable. Henley and Adams (1979) presented evidence that suggested very low efficiencies of 1 to .01 percent, whereas Loen (1992) used 10 to 50 percent in his calculations. Substituting these values in the equation, $P=5,167$ met- 
ric tons of gold, the amount that should have been available for concentration in placers here. Because only 15.6 metric tons of gold have been recovered so far, which is less than 1 percent of 5,167 metric tons, there should still be an abundance of gold remaining. Certainly a vast amount is probably still present as placers but is in too small of concentrations to mine economically, and much of this is probably in the high terrace gravels.

Although the placers in the Fortymile River area have been mined for more than 100 years, there still remains unmined gold in the stream gravel of the area. The rise in the gold price in the early $1980^{\prime} \mathrm{s}$ stimulated a tremendous increase in mining activity, and another burst of activity would probably occur should the price rise sharply again. Gravel that is uneconomic at one gold price becomes economic at a higher price. Consequently, tailings are remined, gravel along the margins of creeks is mined, colluvial gravel marginal to the alluvial gravel is mined, headwater reaches where gradients are steep are mined, new creeks are mined that had not been previously economic, and the downstream parts of creeks where volumes of gravel are high, but values low, are mined. Unmined gravel is present in the floodplains of Walker and Mosquito Forks; Canyon, Napoleon, Dome, Stonehouse, Cherry, Uhler, and Buckskin creeks; and Fortyfive Pup (pl. 1). The largest gold resource remaining in the Fortymile River area is probably in the high terrace gravels exposed along many of the creeks and rivers in the region (pl. 1). Until there is exploratory drilling or some sort of comprehensive sampling program, the gold value in this gravel will remain unknown. 


\section{Placer Mining and Production}

Mining of placer gold deposits has been nearly continuous for more than a century in the Fortymile River area, although mining methods have changed for several reasons. Environmental degradation has become an issue that the mining community has had to address. In recent years, demonstration grant projects financed by the state of Alaska became available for miners as an incentive to improve the "health" of the placer mining industry.

The first decade following the discovery of gold was characterized by simple methods and maximum human labor. Miners used shovels, picks, gold pans, wheelbarrows, rockers, and sluiceboxes (see frontispiece) to extract gold from gravel, as they had for the past 2,000 years (Agricola, 1912). Only the richest parts of the gravel were mined, often by drifting. This type of mining allowed work to progress through the winter months because gold-bearing gravel was hauled out of the drifts to the surface and stockpiled to be sluiced during the spring and summer. A shortage of labor in the early years of mining limited the rate at which the high-

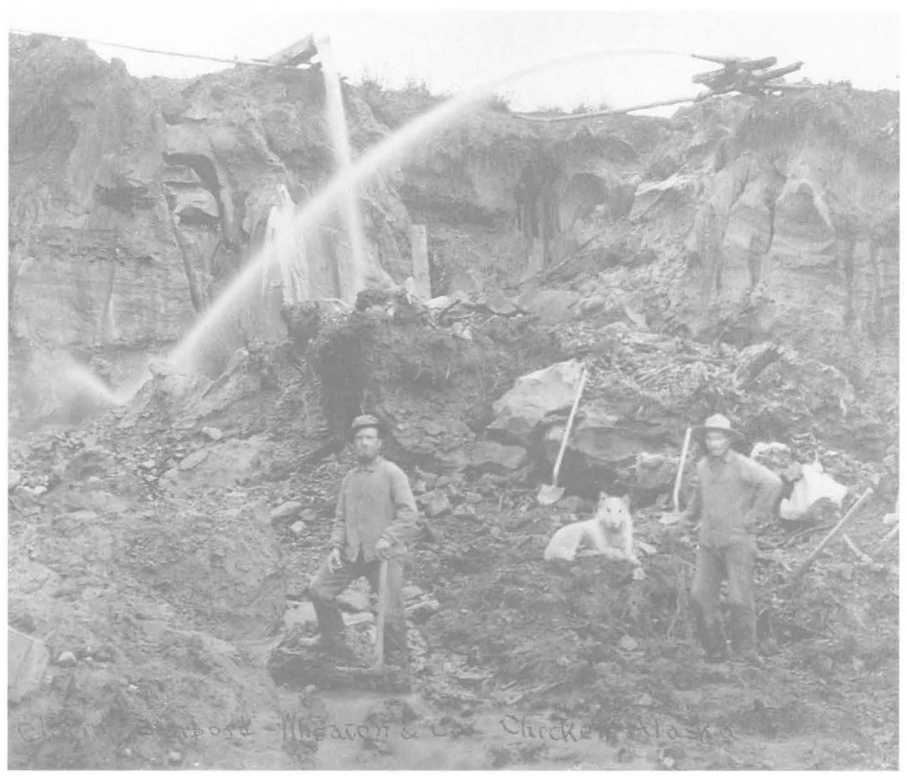
grade gravel was mined. A detailed discussion of these early small-scale mining methods is found in Purington (1905).

By the 1930's, more sophisticated mining methods were used, and these methods included such mechanical equipment as steam-powered shovels, scrapers, draglines, cableway excavators, and the bucketline dredges. Hydraulic mining was widespread in the area by the first decade of the 20th century and was used for many years where ample water was available. Ditches were dug to bring water to many of the hydraulic operations. Bucketline dredges were used for short periods of time over 60 years (1907-1967) on the Fortymile River, Walker Fork, South Fork, Wade Creek, and most recently on Chicken Creek (figs. 20, 21, 23, 27, and cover). A discussion of the methods and costs of mining up until 1930 is presented in detail by Wimmler (1927).

The development of the diesel engine used in bulldozers, draglines, and pumps, as well as the more durable steel sluiceboxes, enabled mining of lower-value gravel

HYDRAULIC MINING in Chicken Creek in 1918. Photograph courtesy of University of Alaska, Fairbanks, Archives.
(Thomas and others, 1959). Backhoes, front-end loaders, elevated trommels, high-pressure hydraulic giants, conveyors, and huge bulldozers, including more sophisticated washing plants combining such features as vibratory classifying stages with efficient sluiceboxes and jigs, have been used in the past two decades (Cook, 1983; Wilkinson, 1984; Colp, 1984; Ackels, 1985).

Mining costs have increased, but so has the price of gold. The cost of hydraulicking in 1926 was $\$ 0.25$ to $\$ 0.50$ per cubic yard ( $\$ 0.19$ to $\$ 0.38$ per cubic meter) with gold at $\$ 20.67$ per ounce (Wimmler, 1927). By 1940 the costs were up to $\$ 1$ per cubic yard (\$0.76 per cubic meter 
(Mathews, 1940). In the 1980's and 1990's, with gold between $\$ 300$ and $\$ 400$ per ounce, costs ranged from $\$ 0.50$ to $\$ 5$ per cubic yard ( $\$ 0.38$ to $\$ 3.80$ per cubic meter), depending on mining method used and site conditions.

Following the precipitous gold price rise in the early 1980's, the number of placer mines in the State greatly increased, which led to concern for the integrity of Alaska's water resources. Stream sedimentation and associated turbidity became a problem because most miners found it difficult to meet the criteria established by the Federal Environmental Protection Agency and Alaska Department of Environmental Conservation. Turbidity is measured in nephelometric turbidity units or NTU. NTU's are a measure of the amount of light scattered by a sample of water. The law states that turbidity should not exceed 25 NTU's above the background level, which is the level that has been determined to not harm stream life. The water in mined streams without settling ponds is much higher-200 to 300 NTU's. Settling ponds are now mandatory for placer mines. Many mines now recycle the wastewater through their washing plants, although recycling is expensive and hinders the recovery of fine gold. The U.S. Bureau of Mines has spent several years experimenting with a flocculant, a water-soluble resin called polyethylene oxide (PEO). The method involves mixing PEO with the dirty water, a process which forms a floc with the clay-size particles. The floc is then separated from the water and the clean water is either recirculated to the washing plant or discharged into the stream. This system, although it requires extra equipment and some technical expertise, can be used in some placer mining situations (Pain, 1987).

The Alaska Legislature, in an attempt to help the mining industry evaluate the most costeffective methods of gold recovery while complying with new Federal and State environmental regulations, established the Placer Mining Demonstration Grants Program in 1985. This program encouraged and helped finance experienced placer miners study and test new methods of (1) fine gold recovery, (2) water use reduction and water pollution control, and (3) waste disposal. Conclusions from Peterson and others (1987) are summarized as follows:

1. There is a small amount ( 16 percent) of fine gold (less than minus- 60 mesh) in the placers, and, therefore, using complex, high-technology recovery equipment to capture this gold is rarely warranted. Classification through washing as well as feed to the sluice is more cost effective in most cases compared to gold-recovery devices added to the end of a sluicebox such as jigs, Reichert spirals, Gyro-Separator, Knudsen bowl, and Knelson concentrator.

2. Simple techniques to reduce water use include classification, recycle, bypass, improved settling ponds, and tailings filtration. Flocculant use requires technical expertise to design an effective system and select the correct flocculant, and although flocculants do work, those available have not consistently produced water quality required by the State and Federal regulations. Vegetative filters such as tundra, although not able to remove all sediment from high concentrations of effluent, are nevertheless useful in cleaning up "dirty" water prior to recirculating or discharge back to the stream system.

3. Using coarse tailings to bury the fine tailings and slimes is a viable method for stabilizing these unwanted mine products. Also, using a slurry pump or hydraulic lift to spray fine tailings on top of coarse tailings is a good method of preparing for revegetation.

Although much of the mining in the Fortymile River area today is done with expensive, sophisticated equipment, there is still a place for small, low-budget mines. There are unmined creeks with small drainage basins that contain gold. These creeks cannot support large mining operations because of their low grade and (or) volume, but they can provide a working wage for a miner and the thrill of finding an occasional nugget or rich pocket to the recreational miner.

Gold production in the Fortymile River area since the gold discovery in 1886 is approximately 500,000 ounces. Yearly records to 1930 (Smith, 1934) indicate that about 350,000 ounces or 70 percent of the total production was recovered by 1930. Approximately 46,000 ounces was produced in the next decade, and about 100,000 ounces has been recovered in the past 50 years. 


\section{+ CONCLUSIONS}

1. The high terrace gravels would seem to be a potential source of unmined placer gold, however, gold values are not uniformly distributed through this gravel, and a comprehensive sampling program would be necessary to locate the rich, economically viable areas within the gravel.

2. Colluvium marginal to creek deposits in steep-sided valleys is often gold-bearing. Much of the unconsolidated gravel within the major drainages of the Fortymile River, South Fork, North Fork, and Mosquito Fork is colluvium.

3. The ancestral Fortymile River and its major tributaries, the North and South Forks, had floodplains 1.2 to about 2 miles ( 2 to 3 kilometers) wide and a gradient of about 4 feet per mile ( 0.76 meters per kilometer). Base-level lowering during the Pleistocene allowed the rivers to cut into their floodplains and develop the youthful characteristics they have today such as the $\mathrm{V}$-shaped canyon, narrow floodplain, and a gradient of at least twice that of the old river.

4. Almost all panned-concentrate samples from the gold-producing creeks and high terrace gravels in the Fortymile area have varying percentages of magnetite ( 20 to 80 percent) and ilmenite (10 to 30 percent) and, samples from creeks draining areas principally composed of metamorphic rocks contain abundant garnet (10 to 30 percent).

5. Most placer gold in the Fortymile River area has been recovered at, or near, the gravel-bedrock contact. The lowermost 3.3 feet ( 1 meter) of gravel and the uppermost 1.6 feet $(0.5$ meter) of bedrock may contain as much as 80 to 90 percent of the gold that is ultimately recovered.

6. Gold fineness ranges from 620 to 927 , but it is difficult to attach any significant geologic meaning to fineness.

7. Gold nuggets are rare, and most gold recovered is in the from of flattened fragments less than 0.1 inch ( 5 millimeters) in greatest dimension.

8. The Fortymile River and its tributaries, the South Fork, Walker Fork, and Mosquito Fork, which were at one time all sites of bucket line dredge operations, are now almost exclusively mined using floating suction dredges.

9. Unmined gold-bearing gravels are present in the floodplain of the Walker Fork valley below Cherry Creek and in low (100 to 130 feet or 30 to 40 meters) terraces along the north side of Walker Fork and east side of Cherry Creek.

10. On the basis of where most gold has been found in the South Fork River valley both by the older bucket dredges and the contemporary suction dredges, it seems likely that the tributary drainages of Lost Chicken, Napoleon, Franklin, and Buckskin Creeks have supplied most gold to the South Fork valley.

11. Wade Creek is known for the occurrence of large gold nuggets for example 25-, 
33-, 56-, and 70- ounce nuggets have been found, and occasionally they are still found in the tailing piles along the creek.

12. A $1 / 4$-acre ( 0.10 hectare), 130 -foot-thick ( 40 meters) section of the high terrace gravel on the north side of Napoleon Creek was mined for placer gold and yielded values estimated to be $\$ 8.50$ per cubic yard ( $\$ 6.46$ per cubic meter).

13. The lowest 3 miles (5 kilometers) of Canyon Creek possesses unmined gravels and would probably contain gold because the gold-rich tributary, Squaw Gulch, has contributed detritus to this section of Canyon Creek.

14. Unmined bench gravel is present along Dome Creek, mainly on the north side, and would seem to have potential for future gold production on the basis of mining similar deposits here earlier in the century.

15. The upper part of Stonehouse Creek does not appear to have been mined and may be a source for placer gold.

16. The unmined high terrace gravels on the south side of Buckskin Creek contain gold, however the gravel is thin ( 3 to 6.5 feet or 1 to 2 meters).

17. The close spatial association of creeks containing placer gold with the quartzite, gneiss, schist, amphibolite, and marble unit suggests that this metamorphic unit may be the gold source.

18. The search for a lode gold source in the Fortymile River region may be in vain, because substantially more gold than has been recovered from the placers can be derived by gradual erosion of large volumes of source rocks that contain background mean gold amounts.

19. Using Leon's mass-balance equation, 5,167 metric tons of gold may exist in the placers of the Fortymile River region, which is less than 1 percent of the recovered amount of 15.6 metric tons.

20. Environmental constraints imposed by Federal and State agencies have slowed, but not stopped, placer mining in the Fortymile River area, and a significant gold price rise would result in more mining.

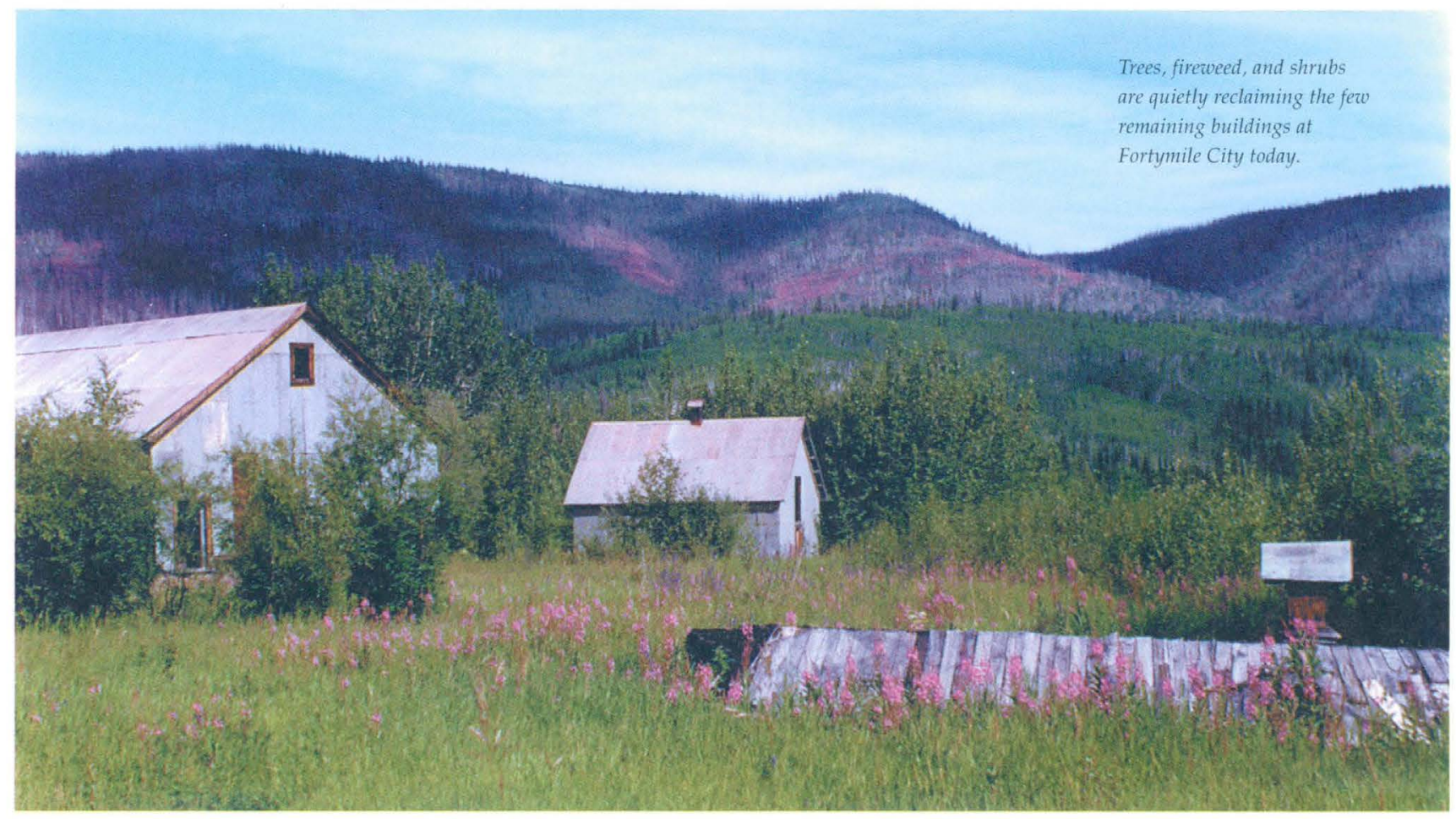




\section{Glossary OF TERMS}

A more detailed definition of the following terms can be found in the Glossary of Geology (1980). Some of the following definitions have been modified from those in the Glossary of Geology (1980), and Placer examination by Wells (1969).

Accreted terrane-A large piece of the Earth's crust that is added or accreted to an already existing land mass.

Alaskite-A term for a granitic rock containing only a few percent dark minerals.

Alluvial-Transported by and deposited by flowing water.

Amphibolite-A dark colored metamorphic rock consisting of mainly the minerals amphibole and plagioclase.

Aplite-A light colored, fine-grained, plutonic igneous rock.

Arkose-A pink or reddish coarse-grained sandstone resembling granite from which it is usually derived.

Asymmetric fold-A fold developed (within rocks) the limbs of which have different angles of dip.

Avoirdupois-System of weights used in the United States were one pound avoirdupois equals 16 ounces.

Barite-A white, yellow, or colorless mineral, which has a specific gravity of 4.5.

Basalt-A common volcanic rock, which is fine grained and dark colored.

Batholith-A large body of plutonic rock.

Bedrock-Solid rock that may outcrop or be overlain by unconsolidated material as soil, tundra, rubble, sand and gravel or colluvium.

Black sand-Heavy grains of various minerals that are dark in color and are usually found accompanying gold in alluvial deposits.

Breccia-A consolidated rock composed of angular rock fragments.

Bucketline dredge-A large floating machine for scooping up or excavating earth material as gold-bearing gravel at the bottom of a body of water, raising it to the surface and separating the gold from the gravel by the use of screens, sluices and other methods.

Calcic-Minerals and rocks that contain a relatively high proportion of calcium.

Chalcopyrite-A bright brass yellow mineral containing copper.

Chert-A hard extremely dense or compact, dull to glassy crystalline rock of any color.

Clast-An individual constituent, grain, or fragment of a sediment or rock produced by the mechanical weathering of a larger rock mass.

Clinopyroxene-A group name for the pyroxene minerals containing considerable calcium.

Colluvium-A general term applied to any loose, heterogeneous, and incoherent mass of soil material and (or) rock fragments deposited at the base of slopes or hillsides.

Conglomerate-A rock that can be called the consolidated equivalent of gravel.

Conglomeratic sandstone-A sandstone containing 5 to 30 percent gravel.

Crinoid Columnal-One of the numerous individual vertical segments that make up the stem of a fossil crinoid.

Detritus-A term for loose rock and mineral material that is worn off or removed by erosion and abrasion as sand, silt or clay derived from older rocks.

Diagenesis-All the chemical, physical, and biologic changes undergone by a sediment after its initial deposition.

Dike-A sheetlike body of igneous rock that was intruded while molten into cracks in older rocks.

Diorite-A group of plutonic rocks intermediate in composition between acidic and basic; generally gray in color. 
Dragline-A power shovel equipped with a long boom and a heavy digging bucket that is suspended from a hoisting line and it pulled toward the machine by means of a "drag" line. Drift mining-The extraction of placer gravel by underground horizontal or inclined tunneling rather than by the use of water.

Dunite-A dark green plutonic rock composed almost exclusively of the mafic mineral olivine.

Epidote-A yellowish-green mineral common in low-grade metamorphic rocks.

Epigenetic-A sedimentary mineral, texture, or structure formed after the deposition of the sediment.

Facies-The aspect, appearance, and characteristics of a rock unit, usually reflecting the conditions of its origin.

Ferruginous sandstone-A sandstone that is cemented with iron oxide.

Fineness-A designation of the purity of gold where 1000 is pure gold.

Floodplain-The surface or strip of relatively smooth land adjacent to a river channel that is covered with water when the river overflows its banks.

Foliation-The planar structure that results from flattening of the mineral grains of a metamorphic rock and gives to the rock a layered or slab-like look.

Garnet-A hard, generally dark red mineral commonly found in metamorphic rock, and because of its relatively high specific gravity is often present in the heavy mineral concentrates obtained in placer mining.

Gneiss-A foliated metamorphic rock commonly showing alternating bands of light and dark minerals.

Granite-A plutonic igneous rock possessing both light and dark minerals which often gives a "salt-and-pepper" appearance to the rock.

Granodiorite-A coarse grained plutonic rock resembling granite, but having slightly different composition.

Granule-A rock fragment larger than a very coarse sand grain and smaller than a pebble. Graywacke-A sandstone that is commonly dark gray, firmly indurated and coarse grained. Greenschist-A schistose metamorphic rock whose green color is due to the presence of the minerals chlorite, epidote, or actinolite.

Greenstone-A term applied to any dark-green altered or metamorphosed basic igneous rock.

Heavy mineral concentrate-The accessory detrital minerals of high specific gravity; the black sand concentrate common to placers.

Harzburgite-A variety of peridotite.

Hematite-A common iron-rich mineral with metallic luster and steel-gray or iron-black in color.

Hornfelsed-Refers to a rock that has been altered (metamorphosed) as a result of heat associated with a nearby intrusive rock.

Hydraulic giant-A device used to direct water under pressure for the purpose of stripping or mining.

Hydraulic monitor-Same as hydraulic giant.

Hydraulicking or hydraulic mining - A method of mining in which a bank of gold bearing earth or gravel is washed away by a powerful jet of water and carried into sluices, where the gold separates from the earth by its specific gravity.

Hydrothermal-Pertaining to hot water, to the action of hot water, or to the products of this action, such as a mineral deposit precipitated from a hot-water solution.

Igneous rock-A rock formed by solidification of hot molten material either at depth in the Earth's crust (plutonic) or erupted at the Earth's surface (volcanic).

Ilmenite-A black opaque mineral commonly present in black sand concentrates.

Intrusion-The process of emplacement of molten rock in pre-existing rock. 
Island arc-A chain of islands rising from the deep-sea floor near the continents.

Isoclinal-A fold whose limbs are parallel.

Joint-A fracture along which there has been little or no movement parallel to the fracture plane.

Lacustrine-Pertaining to, produced by, or formed in a lake or lakes.

Lignitic coal-A low grade of coal.

Limonite-General term for a group of brown, naturally occurring iron oxides.

Lithology-The physical character of a rock such as color, mineralogic composition, and grain size.

Lode-The occurrence of a valuable mineral-bearing body in the country rock, such as vein or fissure, as opposed to placer deposits.

Ma-An abbreviation for mega-annum $(1,000,000$ years)

Mafic rock-An igneous rock composed chiefly of one or more dark-colored minerals.

Magnetite-A black, strongly magnetic, opaque mineral; a common mineral within black sand concentrates.

Manganese oxide-A black to brown, friable laminated concretionary mass often existing as coatings on rocks.

Marble-A metamorphic rock consisting predominantly of fine to coarse-grained recrystallized calcite.

Mass-wasted deposit-A general term for a surficial deposit produced by the dislodgement and downslope transport of soil and rock material under the direct application of gravity.

Matrix-The finer-grained material enclosing or filling the interstices between the larger grains or particles of a sediment or sedimentary rock.

Meander-One of a series of somewhat regular and looplike bends in the course of a stream. Meta-A prefix that, when used with the name of a sedimentary or igneous rock indicates that the rock has been metamorphosed.

Metamorphic grade-The intensity or rank of metamorphism.

Metamorphic rock-Rock changed materially in composition or appearance by heat, pressure, or infiltrations at depth in the Earth's crust.

Metasedimentary rock-A sedimentary rock that shows evidence of having been subjected to metamorphism.

Open cut-A mining process in which the working area is at the Earth's surface.

Paystreak-The horizontal limits of economic value in a placer deposit.

Pebble count-The procedure of counting the number and determining the percentages of different rock types represented in a gravel deposit at a particular locality; generally 50 to 100 pebbles are used in the count.

Pegmatite-An exceedingly coarsely crystalline plutonic rock, commonly in dikes or pods a few feet across.

Pelitic-Pertaining to a characteristic of a rock that is composed of abundant clay-size particles.

Periglacial-An environment at the immediate margins of former and existing glaciers and ice sheets that is influenced by the cold temperature of the ice.

Peridotite-A general term for a dark greenish-colored coarse-grained plutonic rock composed chiefly of the mineral olivine.

Permafrost-Permanently frozen ground.

Phenocryst-A term used for a relatively large, conspicuous crystal or mineral in an igneous rock.

Phyllite-A metamorphosed rock intermediate in grade between a slate and a mica schist. Placer-A surficial mineral deposit formed by mechanical concentration of mineral particles from weathered debris.

Pleistocene-The unit of geologic time immediately following the Tertiary characterized by 
multiple periods of glaciations. It began two to three million years ago and lasted until the start of the Holocene some 8,000 years ago

Plutonic rock-Igneous rock formed by solidification of magma deep within the Earth's crust.

Potassium-argon dating-Determination of the age of a mineral or rock in years, based on measurement of the ration of radiogenic argon to potassium.

Protolith-The unmetamorphosed rock from which a given metamorphic rock was formed by metamorphism; the parent rock.

Pyrite-A common brass-yellow, metallic mineral that contains the elements iron and sulphur.

Quartz diorite-A plutonic rock having the composition of diorite but with and appreciable amount of quartz.

Quartzite-A very hard metamorphic rock consisting mainly of quartz and formed by recrystalization of sandstone or chert.

Quartz monzonite-A granite-like plutonic rock in which quartz makes up less than 20 percent of the rock.

Rock cleavage-The property or tendency of a rock to split along aligned fractures.

Rocker-A wooden box with included screens used by a placer miner with the aid of water to separate gold and other heavy minerals from gravel.

Sandstone-A medium-grained sedimentary rock composed of rounded or angular sandsize fragments and generally containing a high percentage of the mineral quartz.

Scheelite-A yellow-white or brown mineral occurring in veins associated with quartz.

Schist-A crystalline metamorphic rock composed chiefly of platy mineral grains. The rock has a tendency to split into layers or slabs.

Sedimentary rock-Rock formed by consolidation of sediment (gravel, sand, mud) deposited at the surface of the Earth.

Sericitized bedrock-A white fine-grained mica occurring in small flakes as an alteration product in various metamorphic rocks especially schists and phyllites.

Serpentine-A group of common rock-forming minerals that are generally greenish to yellow green in color and have a waxy, silky luster and a soapy feel.

Shale-A fine-grained sedimentary rock formed by the consolidation of clay, silt, or mud.

Shear-A deformation resulting from stresses that cause or tend to cause contiguous parts of a body to slide past each other.

Shoveling-in-An old mining term for a method of mining placers where gold-rich gravel is hand-shoveled directly from its place of occurrence into a sluice box.

Siltstone-A sedimentary rock made up of silt-size particles.

Six-step spectrographic method-A laboratory technique used to determine the presence of various elements in a rock or mineral sample.

Sluice box-An elongated wooden or metal trough, equipped with riffles, through which alluvial material is washed to recover its gold or other heavy minerals.

Solifluction-The slow downslope flow of waterlogged soil and other unsorted and saturated surficial material in regions underlain by frozen ground.

Specific gravity-The specific gravity of a substance is its weight compared with the weight of an equal bulk of pure water. For example, placer gold with a specific gravity of about 19 is 19 times heavier than water. The specific gravity of a mineral largely determines its susceptibility to recovery in simple gravity concentrators such as sluice boxes.

Steam point-Water pipes driven into frozen ground through which steam is pumped to thaw the ground before mining, usually dredging.

Stratigraphy-The science of rock strata. It is concerned not only with the original succession and age relations of rock strata but also with their form, distribution, composition, and fossil content. 
Suction dredge-A dredge in which material is excavated to the surface by a suction pump and the material is then put through a sluice box to separate the contained gold fragments. Sulfides-Minerals characterized by the presence of sulfur with a metal, such as pyrite and chalcopyrite.

Surficial deposit-Unconsolidated and residual, alluvial, or glacial deposits laying on bedrock or occurring on or near the Earth's surface.

Tailings-The waste or valueless material left after removing the valuable minerals.

Tephra-A general term applied to all particles ejected during a volcanic eruption; commonly refers to a volcanic ash bed.

Terrane-A term applied to a rock or group of rocks and to the area in which they crop out. Tertiary-The unit of geologic time thought to have covered the span of time between 65 and three to two million years ago.

Trace element-An element that is not essential in a mineral but that is found in small quantities in its structure.

Tuff-Rock formed by consolidation of volcanic ash.

Tuffaceous-Refers to sediments that contain as much as 50 percent tuff.

Ultramafic rock-A general name for plutonic rocks composed almost exclusively of mafic minerals that are dark to very dark in color.

Wacke-A "dirty" sandstone that consists of a mixed variety of angular and poorly sorted mineral and rock fragments and of an abundant matrix of clay and fine silt.

Zircon-A mineral that is commonly found as small crystals in igneous rocks. Because of its resistance to weathering and moderate specific gravity, zircon is a common constituent of the black sands associated with gold placers. 


\section{REFERENCES Cited}

Ackels, Del, 1985, Some aspects of gold covery with IHC jigs, in Madonna, A., ed., Proceedings of the seventh annual conference on Alaskan placer mining: Fairbanks, Alaska, Prospectors Publishing, p. 86-99.

Agricola, Georgius,1912, de re metallica [on the study of metals] (translated from the first Latin edition of 1556, by H.C. Hoover and L.A. Hoover): The Mining Magazine, $640 \mathrm{p}$.

Archer, S.A., compiler, 1929, A heroine of the North: Memoirs of Charlotte Selina Bompas: London, Society for promoting Christian Knowledge, $187 \mathrm{p}$.

Ayer, A.S., 1946, Steel Creek, in The Alaskan Sportsman, v. 12, no. 5, 16 p.

Bates, R.L., and Jackson, J.A., editors, 1980, Glossary of Geology, second edition; American Geological Institute, Falls Church, Virginia, $751 \mathrm{p}$.

Berton, Pierre, 1958, The Klondike Fever: New York, Alfred A. Knopf, 457 p.

Boyle, R.W., 1979, The geochemistry of gold and its deposits: Geological Survey of Canada Bulletin 280, $584 \mathrm{p}$.

Brooks, A.H., 1910, Mineral resources of Alaska: Report on progress of investigations in 1909: U.S. Geological Survey Bulletin 442, 437 p.

1916, The Alaska mining industry in 1915: U.S. Geological Survey Bulletin 642, p. 16-71.

1953, Blazing Alaska's Trails: Caldwell, Idaho, The Caxton Printers, 528 p.

Buteau, Frank, 1967, My experiences in the world, in Heller, H.L., ed., Sourdough Sagas: The World Publishing Company, p. 93-118.

Churkin, Michael, Jr., Foster, H.L., Chapman, R.M., and Weber, F.R., 1982, Terranes and suture zones in east-central Alaska: Journal of Geophysical Research, v. 87, no. B5, p. 3718-3730.

Clark, D.W., 1995, Fort Reliance, Yukon: an archaeological assessment, Archaeological Survey of Canada, paper 150, Canadian Museum of Civilization, $247 \mathrm{p}$.

Clark, W.G., 1978, Gold rush of the 1970's: California Geology, v. 31, no. 9, p. 203-205.

Cobb, E.H., 1973, Placer deposits of Alaska: U.S. Geological Survey Bulletin 1374, 213 p.

Colp, D.B., 1984, Mining and recovery techniques on Eagle Creek, in Sixth Annual Conference on Alaskan Placer Mining: Fairbanks, University of Alaska Mineral Industry Research Laboratory Report 69, p. 23-26.

Constantine, Inspector Charles, 1895, Report of Inspector Constantine, 10th October,1894, in Report of the Commissioner of the North-West Mounted Police Force, 1894: Ottawa: The Queens's Printer.

Cook, D.J., 1983, Placer mining in Alaska: Fairbanks, University of Alaska Mineral Industry Research Laboratory Report 65, $157 \mathrm{p}$.

Couch, Jim, 1957, Highway to history, in The Alaskan Sportsman, v. 23, no. 1, p. 10.

Crocket, J.H., 1991, Distribution of gold in the Earth's crust, in Foster, R.P., ed., Gold metallogeny and exploration: Blackie, London, p. 1-36.

Davis, Henry, 1967, Recollections, in Heller, H.L., ed., Sourdough Sagas: The World Publishing Company, p. 28-84.

Dial, Scott, 1975, The gold rush saloon: The Alaska Journal, v. 5, no. 2, p. 81-88.

Dunham, S.C., 1898, The Alaskan gold fields and the opportunities they offer for capital and labor: Department of Labor Bulletin, no. 14, p. 297-495.

Dusel-Bacon, Cynthia, and Hansen, V.L., 1991, High-pressure, medium-temperature early Mesozoic metamorphism and deformation within the Yukon-Tanana composite terrane, eastern Alaska [abs.]: Geological Society of America Abstracts with Programs, v. 23 , no. 2 , p. 20. 
1992, High-P, moderate-T metamorphism and ductile deformation during Early Mesozoic subduction and accretion, east-central Alaska [abs.]: Geological Society of America Abstracts With Programs, v. 24, no. 5, p. 21.

Eberlein, G.D., Chapman, R.M., Foster, H.L, and Gassaway, J.S., 1977, Map and table describing known metalliferous and selected nonmetalliferous mineral deposits in central Alaska: U.S. Geological Survey Open-File Report 77-168D, 132 p., 1 sheet, scale $1: 1,000,000$.

Ellsworth, C.E., and Davenport, R.W., 1913, Placer mining in the Yukon-Tanana region: U.S. Geological Survey Bulletin 542, p. 203-222.

Ellsworth, C.E., and Parker, G.L., 1911, Placer mining in the Yukon-Tanana region: U.S. Geological Survey Bulletin 480, p. 153-172.

Forbes, R.B., 1980, Chemical zonation in gold nuggets, in Second Annual Conference on Alaskan Placer Mining-Focus on gold: Fairbanks, University of Alaska Mineral Industry Research Laboratory Report 46, p. 72-77.

Foster, H.L., 1969, Reconnaissance geology of the Eagle A-1 and A-2 quadrangles, Alaska: U.S. Geological Survey Bulletin 1271-G, 30 p.

1976, Geologic map of the Eagle quadrangle, Alaska: U.S. Geological Survey Miscellaneous Investigations Map I-922, scale 1:250,000.

1992, Geologic map of eastern Yukon-Tanana Region, Alaska: U.S. Geological Survey Open-File Report 92-213, 26 p., 1 plate

Foster, H.L., and Clark, S.H.B., 1970, Geochemical and geologic reconnaissance of a part of the Fortymile Area, Alaska: U.S. Geological Survey Bulletin 1312-M, 29 p.

Foster, H.L., and Keith, T.E.C., 1969, Geology along the Taylor Highway, Alaska: U.S. Geological Survey Bulletin 1281, $36 \mathrm{p}$.

Foster H.L, and O'Leary, R.M., 1982, Gold found in bedrock of Lost Chicken Creek gold placer mine, Fortymile area, Alaska: U.S. Geological Survey Circular 844, p. 62-63.

Foster, H.L., Weber, F.R., Forbes, R.B., and Brabb, E.E., 1973, Regional geology of YukonTanana Upland, Alaska, in Arctic geology: American Association of Petroleum Geologists Memoir no. 19, p. 388-395.

Foster, H.L., Keith, T.E.C., and Menzie, W.D., 1987, Geology of east-central Alaska: U.S. Geological Open-File Report 87-188, 59 p.

Funston, Frederick, 1896, Over the Chilkoot Pass to the Yukon, Scribner's Magazine, v. 20, p. 572-585.

Gates, Michael, 1994, Gold at Fortymile Creek: UBC Press, Vancouver, Canada, 200 p.

Griffiths, C.E., 1900, From Knik Station to Eagle City, in Compilation of Narratives of Explorations in Alaska, 1900, U.S. Government Senate Report 1023, 56th Congress, 1st session, p. 724-733.

Hayne, M.H.E., and Taylor, H.W., 1897, Pioneers of the Klondike: London, Sampson, Low, Marston and Co., $184 \mathrm{p}$.

Haynes, T.L., 1976, They didn't come in four-wheel drives: An introduction to Fortymile history: Bureau of Land Management report, Fortymile Resource Area, Tok, Alaska, $99 \mathrm{p}$.

Heller H.L., 1967, Sourdough Sagas: The World Publishing Company, 273 p.

Henley, R.W., and Adams, J., 1979, On the evolution of giant gold placers: Institute Mining Metallurgy Trans., v. 88, p. B41-B50.

Johnson, A.J., 1990, Carmack of the Klondike: Epicenter Press and Horsdal \& Schubart, Ganges, British Columbia, Canada 166 p.

Jones, D.L., Silberling, N.J., Coney, P.J., and Plafker, George, 1984, Lithotectonic terrane map of Alaska (west of the 141st Meridian), Part A, in Silberling, N.J., and Jones, D.L., eds., Lithotectonic terrane maps of the North America Cordillera: U.S. Geological Survey Open-File Report 84-523, p. A1-A12. 
La Roche, F., 1898, En route to the Klondike...a series of photographic views of the picturesque land of gold and glaciers: Chicago and New York, W.B. Conkey Co., unpaginated.

Loen, J.S., 1992, Mass balance constraints on gold placers: Possible solutions to "source area problems:" Economic Geology, v. 87, p. 1624-1634.

London, Jack, 1903, The gold-hunters of the north: Atlantic Monthly, v. 92, 8 p.

Mackenzie, B.W., 1991, Economics of gold deposits, in Foster, R.P., ed., Gold metallogeny and exploration: London, Blackie, p. 399-426.

Mathews, R.T., 1940, Placer mining methods and costs in the Circle District, Alaska: College, Alaska, University of Alaska, Bachelor of Science in Mining Engineering thesis, $80 \mathrm{p}$.

McConnell, R.G., 1905, Report on the Klondike Gold Fields, Geological Survey of Canada, Annual Report, v. XIV, pt. B, 71 p.

McQuesten, L.N., 1952, Recollections of Leroy N. McQuesten of life in the Yukon, 1871-1885, Dawson City: Yukon Order of Pioneers, $14 \mathrm{p}$.

Mertie, Evelyn, 1982, Thirty summers and a winter: Fairbanks, University of Alaska Mineral Industry Research Laboratory, $187 \mathrm{p}$.

Mertie, J.B., Jr., 1930, Mining in the Fortymile district: U.S. Geological Survey Bulletin 813, p.125-142.

1937, The Yukon-Tanana region, Alaska: U.S. Geological Survey Bulletin 872, 276 p.

1938, Gold placers of the Fortymile, Eagle, and Circle districts, Alaska: U.S. Geological Survey Bulletin 897-C, p. 133-261.

Metz, P.A., 1987, Geological factors governing the formation of the gold placer deposits of the Fairbanks Mining District, Alaska, in Albanese, Mary, and Campbell, Bruce, compilers: Proceedings of the Ninth Annual Alaska Conference on Placer Mining, Fairbanks, Alaska, $315 \mathrm{p}$.

Metz, P.A., and Hawkins, D.B., 1981, A summary of gold fineness values from Alaska placer deposits: Fairbanks, University of Alaska Mineral Industry Research Laboratory Report No. 45, 63 p.

Morrison, S.R., and Hein, F.J., 1987, Sedimentology of the White Channel gravels, Klondike area, Yukon Territory: Fluvial deposits of a confined valley, in Ethridge, F.T. and others, eds., Recent developments in fluvial sedimentology: Society of Economic Paleontologists and Mineralogists Special Publication 39, p. 205-216.

Naeser, N.D., Westgate, J.A., Hughes, O.L., and Péwé, T.L., 1982, Fission-track ages of late Cenozoic distal tephra beds in the Yukon Territory and Alaska: Canadian Journal of Earth Sciences, v. 19, p. 2167-2178.

Naske, Claus-M., 1977, The historic Forty-Mile District: The Northern Engineer, v. 8, no. 2, p. 38-55.

Ogilvie, William, 1890, Exploratory survey of the Lewes, tat-on-duc, Porcupine, Bell, Trout, Peel, and Mackenzie Rivers: Ottawa, Canada, printed by Brown Chamberlin, printer to the Queen's most excellent majesty, $113 \mathrm{p}$.

1897, Information respecting the Yukon District: Ottawa: Department of the Interior, Government Printing Office, $65 \mathrm{p}$.

1898, The Klondike official guide: Toronto, Canada, The Hunter Rose Co. Ltd., 145 p. 1913, Early days on the Yukon and the story of its gold finds: Ottawa: Thorburn and Abbott.

Orth, D.J., 1967, Dictionary of Alaska place names: U.S. Geological Survey Professional Paper 567, $1084 \mathrm{p}$.

Pain, Stephanie, 1987, After the gold rush: New Scientist, v. 115, no. 1574, p. 36-40. 
Parker, B.H. Jr., 1992, Gold panning and placering in Colorado: Colorado Geological Survey Information Series no. 33, Colorado Geological Survey Department of Natural Resources, Denver, Colorado, $83 \mathrm{p}$.

Paterson, T.W., 1977, Ghost towns of the Yukon: Langley British Columbia, Canada, Stagecoach Press, $148 \mathrm{p}$.

Peterson, L.A., Hanneman, R.C., and Tsigonis, R.C., 1987, Placer mining demonstration grant project, final report: Prepared for: State of Alaska Department of Environmental Conservation, [available from L.A. Peterson \& Associates, Inc., Fairbanks, Alaska] $113 \mathrm{p}$.

Péwé, T.L., 1975, Quaternary geology of Alaska: U.S. Geological Survey Professional Paper $835,145 \mathrm{p}$.

Porter, E.A., 1912, Placer mining in the Fortymile, Eagle, and Seventymile River Districts: U.S. Geological Survey Bulletin 520, p. 211-218.

Porter, Lee, 1985, Late Pleistocene Fauna of Lost Chicken Creek, Alaska: Ph.D. dissertation, Pullman, Washington State University, 173 p.

Prindle, L.M., 1905, The gold placers of the Fortymile, Birch Creek, and Fairbanks regions, Alaska: U.S. Geological Survey, Bulletin 251,89 p.

1908, The Fortymile gold placer district: U.S. Geological Survey Bulletin 345, p. 187197.

1909, The Fortymile quadrangle, Yukon-Tanana region, Alaska: U.S. Geological Survey Bulletin 375, $52 \mathrm{p}$.

Purington, C.W., 1905, Methods and costs of gravel and placer mining in Alaska: U.S. Geological Survey Bulletin 263, $263 \mathrm{p}$.

Scott, Elva, 1990, Historic Eagle and its people: published by Elva Scott, Eagle City, Alaska, unpaginated.

Smith, P.S., 1934, Past placer-gold production from Alaska: U.S. Geological Survey Bulletin 857, p. 93-98.

1939, Mineral industry of Alaska in 1938, U.S. Geological Survey Bulletin 917-A, p. 1113.

1942, Mineral industry of Alaska in 1940, U.S. Geological Survey Bulletin 933-A, p. 1102.

Specht, Robert, 1976, Tisha: New York, St. Martin's Press, 358 p.

Spence, C.C., 1996, The Northern gold fleet, Twentieth-century gold dredging in Alaska: University of Illinois Press, Urbana and Chicago, $302 \mathrm{p}$.

Spurr, J.E., 1898, Geology of the Yukon gold district, Alaska: U.S. Geological Survey 18th Annual Report, pt. 3, p. 87-392.

1900, Through the Yukon gold diggings: Boston, Eastern Publishing Co., $276 \mathrm{p}$.

Tempelman-Kluit, D.J., 1976, The Yukon crystalline terrane: Enigma in the Canadian Cordillera: Geological Society of America Bulletin, v. 87, p. 1343-1357.

Thomas, B.I., Cook, D.J., Wolff, Ernest, and Kerns, W.H., 1959, Placer mining in Alaska: Methods and costs at operations using hydraulic and mechanical excavation equipment with nonfloating Washington plants: U.S. Bureau of Mines Information Circular 7926, $34 \mathrm{p}$.

Webb, Melody, 1985, The Last Frontier: Albuquerque, University of New Mexico Press, 416 p.

Wells, E.H., and Sherman, R., 1974, Down the Yukon and up the Fortymile-further adventures of the expedition sponsored by Frank Leslie's Illustrated Newspaper: The Alaska Journal, v. 4, no. 4, p. 205-213. 
Wells, J.H., 1969, Placer examination principles and practice: U.S. Bureau of Land Management, Technical bull. \#2, $155 \mathrm{p}$.

Wharton, D. B., 1972, The Alaska Gold Rush: Bloomington, Indiana University Press, 302 p.

Whitmore, F.C., Jr., and Foster, H.L., 1967, Panthera atrox (Mammalia: Felidae) from central Alaska: Journal of Paleontology v. 41, p. 247-251.

Wickersham, James, 1938, Old Yukon, tales-trails- and trials: Washington D.C., Washington Law Book Co., $514 \mathrm{p}$.

Wilson, R.W., 1951, Steel Creek, in Alaskan Sportsman, May 1951, p. 12.

Wilkinson, Fred, 1984, Excavating frozen muck, in Sixth Annual Conference on Alaskan Placer Mining: Fairbanks, University of Alaska Mineral Industry Research Laboratory Report 69, p. 20-22.

Wimmler, N.L., 1927, Placer mining methods and costs in Alaska: U.S. Bureau of Mines Bulletin 257, $236 \mathrm{p}$.

Wright, A.A., 1976, Prelude to Bonanza-the discovery and exploration of the Yukon: British Columbia, Canada, Gray's Publishing Ltd., 321 p.

Yeend, W.E., 1974, Gold-bearing gravel of the ancestral Yuba River, Sierra Nevada, California: U.S. Geological Survey Professional Paper 772, 44 p.

Yeend, Warren, 1990, Gold placers, gold source, and high terrace gravels in the Fortymile River area, Alaska, in Bradley, D.C., and Ford, A.B., eds., Geologic studies in Alaska by the U.S. Geological Survey, 1990: U.S. Geological Survey Bulletin 1999, p. 228-230. 1991, Gold placers of the Circle District, Alaska-past, present, and future: U.S. Geological Survey Bulletin 1943, 42 p. 